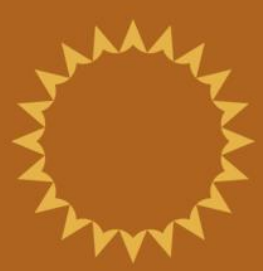

FAUUSP

\title{
FAVELAS NA METRÓPOLE DE SÃO PAULO um olhar sobre a territorialidade e a precariedade dosassentamentos recentes
}

\section{SACHA SENGER}

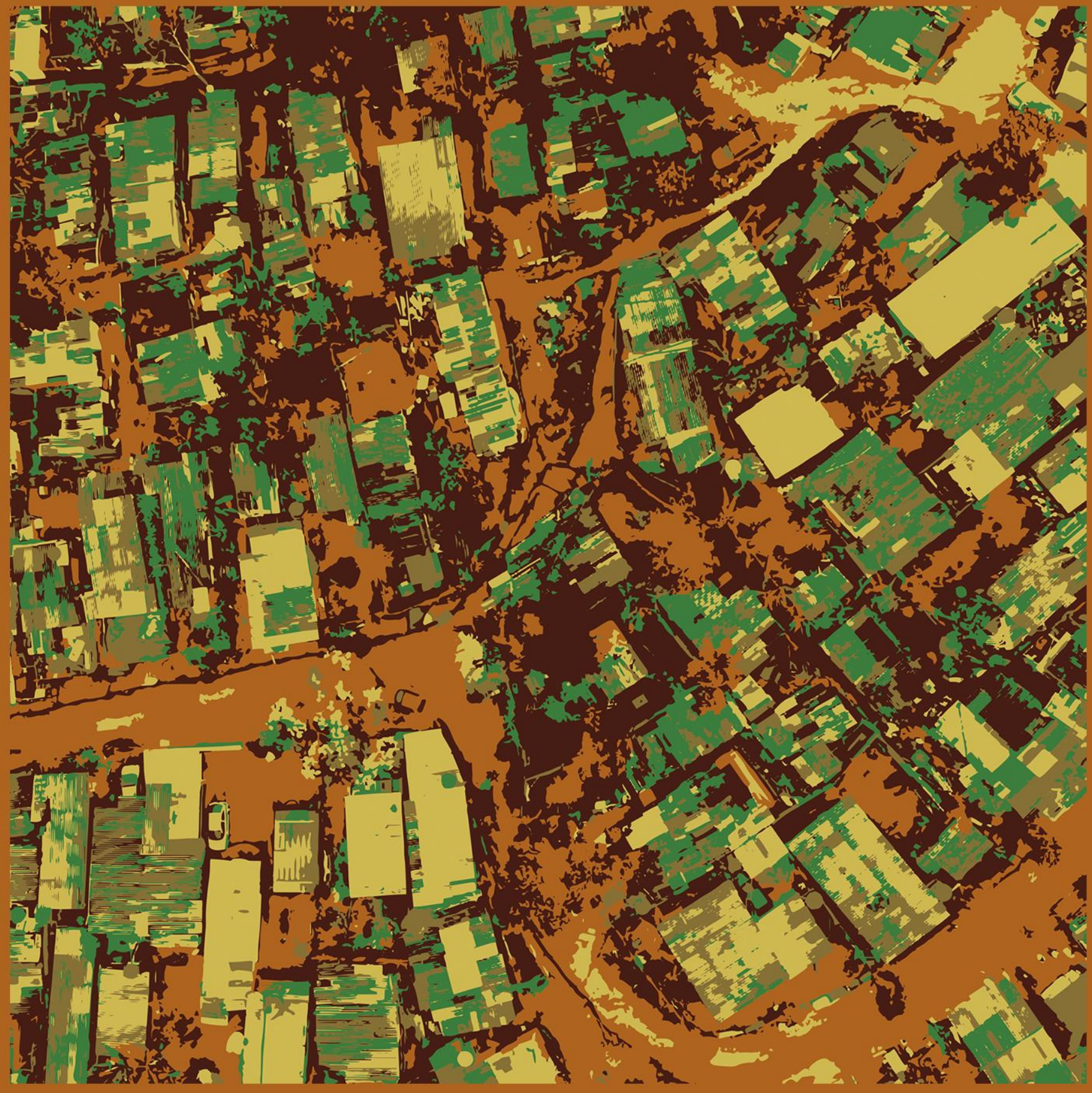





\title{
SACHA SENGER
}

\author{
FAVELAS NA METRÓPOLE DE SÃO PAULO: \\ UM OLHAR SOBRE A TERRITORIALIDADE E A PRECARIEDADE \\ DOS ASSENTAMENTOS RECENTES
}

Dissertação apresentada à Faculdade de Arquitetura e Urbanismo da Universidade de São Paulo para obtenção do título de Mestre em Ciências.

Programa de Arquitetura e Urbanismo Área de concentração: Habitat

Linha de pesquisa: Indicadores e Fundamentos Sociais do Habitat

Orientadora: Prof ${ }^{\mathrm{a}}$. Dr ${ }^{\mathrm{a}}$. Suzana Pasternak

Exemplar revisado e alterado em relação à versão original, sob responsabilidade da autora e anuência da orientadora. A versão original, em formato digital, ficará arquivada na Biblioteca da Faculdade.

São Paulo, 3 de junho de 2019. 
Autorizo a reprodução e divulgação total ou parcial deste trabalho, por qualquer meio convencional ou eletrônico, para fins de estudo e pesquisa, desde que citada a fonte.

E-mail da autora: sachasenger@gmail.com

Catalogação na Publicação

Serviço Técnico de Biblioteca

Faculdade de Arquitetura e Urbanismo da Universidade de São Paulo

Senger, Sacha

Favelas na metrópole de São Paulo: um olhar sobre a territorialidade e a precariedade dos assentamentos recentes / Sacha Senger; orientadora Suzana Pasternak. - São Paulo, 2019.

$131 \mathrm{p}$.

Dissertação (Mestrado) - Faculdade de Arquitetura e Urbanismo da Universidade de São Paulo. Área de concentração: Habitat.

1. Favelas. 2. Favelas (aspectos Urbanísticos). 3. São Paulo. 4. Precariedades Habitacionais. I. Pasternak, Suzana, orient. II. Título. 


\section{FOLHA DE APROVAÇÃO}

SENGER, Sacha. Favelas na metrópole de São Paulo: um olhar sobre a territorialidade e a precariedade dos assentamentos recentes. 2019. Dissertação apresentada à Faculdade de Arquitetura e Urbanismo da Universidade de São Paulo para a obtenção do título de mestre em Ciências.

Aprovada em: 26 de abril de 2019.

Prof $^{a}$. Dr ${ }^{\mathrm{a}}$. Madianita Nunes da Silva

Instituição: Universidade Federal do Paraná

Julgamento:

Assinatura:

$\operatorname{Prof}^{\mathrm{a}}$. Dr ${ }^{\mathrm{a}}$. Rosana Denaldi

Instituição: Universidade Federal do ABC

Julgamento:

Assinatura:

Prof $^{\mathrm{a}}$. Dr ${ }^{\mathrm{a}}$. Suzana Pasternak

Instituição: Universidade de São Paulo

Julgamento:

Assinatura: 

A Casa

Era uma casa

Muito engraçada

Não tinha teto

Não tinha nada

Ninguém podia

Entrar nela não

Porque na casa

Não tinha chão

Ninguém podia

Dormir na rede

Porque na casa

Não tinha parede

Ninguém podia

Fazer pipi

Porque penico

Não tinha ali

Mas era feita

Com muito esmero

Na Rua dos Bobos

Número zero

Vinicius de Moraes 



\section{AGRADECIMENTOS}

Sem uma grande rede de apoio este trabalho jamais teria sido concluído. Agradeço a todos que contribuíram e estiveram comigo nessa caminhada.

À CAPES, pela bolsa concedida, que me possibilitou dedicação integral ao mestrado no último ano.

À minha orientadora Suzana Pasternak, pelas discussões, pertinentes intervenções e pelo apoio ao longo desses dois anos.

Às professoras da Banca de Qualificação, Karina Leitão e Rosana Denaldi, pelas contribuições que me permitiram dar importantes passos para a finalização da pesquisa.

Ao TETO Brasil, que me possibilitou vivenciar momentos inesquecíveis, pelos aprendizados e pela maturidade alcançada. Pela oportunidade de descobrir coisas em mim mesma que antes eu desconhecia.

A todos que, de alguma forma, contribuíram na implementação do TETO Paraná (ou TELHA, para os íntimos), pessoas especiais com quem compartilhei o ideal de um país mais justo.

À equipe de voluntários de Diagnóstico e Avaliação, pela dedicação incondicional, pelo esforço, por transformarem em realidade inúmeros sonhos que tínhamos em comum.

À equipe do TETO Brasil, mas principalmente a Rafaela Alcântara, pelo carinho e apoio sempre presentes, e a Bruno Albuquerque, meu sucessor, companheiro de luta, de trabalho, que orgulho tenho de ser sua amiga!

A Camila Darwiche e Barbara Herthel (a Biba), pessoas que herdei da jornada TETO e que hoje compartilham comigo o nosso próprio teto.

Aos amegos da faculdade sempre tão queridos e prestativos, em especial a Bruno Nascimento, quem fez a linda arte de capa, Ana Cláudia Fróes (a Cacá), pelas trocas e interlocuções, e Débora Furlan, minha fiel revisora de resumos e textos em inglês. 
A todos que fizeram acontecer a disciplina AUP 276 no último semestre, em especial à professora Maria de Lourdes Zuquim (a Lurdinha), quem me tratou com tanto carinho, me estendeu a mão tantas vezes e me abriu portas que eu não achava que conseguiria adentrar. E a Isadora Marchi por todas as conversas e ajudas no último ano.

Aos meus antecessores de TETO, Gabriel Figueiredo (o Biru) e Marina Harkot, por me orientarem e me mostrarem sempre os melhores caminhos.

A Alex Sartori, quem me ensinou a amar São Paulo e acreditou no meu potencial em momentos em que eu me sentia tão insegura.

A Karen Nunes, por me colocar nos trilhos novamente e não me deixar esquecer quem eu sou.

A Fabiana Lopes, quem revisou de maneira tão cuidadosa todos os textos. Agradeço pelo amor, companhia, carinho e acolhimento principalmente nessa reta final.

Ao meu pai, quem me deixou no meio dessa jornada, mas que muito se orgulhava das minhas conquistas.

À minha irmã, Lara Senger, quem me enche de orgulho e não imagina o quão inspiradora é para mim.

À minha mãe, pelo amor incondicional e por todas as batalhas que precisou vencer para que eu chegasse onde cheguei. 



\section{RESUMO}

Notou-se, nos últimos anos, um aumento considerável de novos núcleos de favelas que diferem, principalmente em grau de precariedade, das favelas mais antigas. No entanto, não há dados oficiais em escala metropolitana que possam mensurar e analisar territorialmente essas transformações que vêm ocorrendo no meio urbano. Desse modo, o presente trabalho tem como objetivo geral contribuir com informações relacionadas à precariedade e à territorialidade de favelas surgidas após 2010, data do último censo demográfico, nas regiões periféricas da metrópole de São Paulo. Esses novos espaços de moradia estão sendo denominados nesta pesquisa de "favelas recentes". Por meio da comparação de imagens de satélites de diferentes anos, foi possível detectar padrões temporais de crescimento, contabilizar o número de novos aglomerados formados e estimar o total de construções que surgiram entre os anos de 2010 e 2017. Buscou-se, também, compreender as causas de surgimento dessas favelas, em que, além da relação com a crise econômica, foi analisada a inserção delas nos zoneamentos municipais. Comprovou-se, por meio de análise cartográfica, que o processo de revisão do Plano Diretor de São Paulo, em 2014, teve influência em dinâmicas de surgimento de novos assentamentos em determinadas áreas. Por fim, a partir de quatro estudos de caso, foram exploradas as principais características socioespaciais, destacando a extrema precariedade das favelas recentes.

Palavras-chave: Favelas, Favelas (Aspectos Urbanísticos), São Paulo, Precariedades Habitacionais. 


\begin{abstract}
In recent years, there has been a considerable increase in the number of new slums that differ, mainly in the degree of precariousness, from the older slums. However, there are no official data in metropolitan scale that can measure and territorially analyze transformations that have been taking place in urban areas. Thus, the present work aims to contribute with information related to the precariousness and territoriality of the slums that emerged in the peripheral regions of the metropolis of São Paulo after 2010, year of the last demographic census. This study calls these spaces "recent slums". By comparing satellite images from different years, it was possible to detect temporal patterns of growth, to count the number of new slums and to estimate the total number of buildings that emerged in these slums between 2010 and 2017. The reflections were aimed at understanding the causes of the emergence of these slums, beyond the relation with the macroeconomic crisis, and analyzing their insertion in the municipal zoning. The analysis of cartographic information proved that the review process of São Paulo's Master Plan, in 2014, influenced the dynamics of new slums in some areas of the city. Finally, four case studies were analyzed according to their main socio-spatial characteristics were explored, highlighting the extreme precariousness of the recent slums.
\end{abstract}

Keywords: Slum, Slums (Urban Aspects), São Paulo, Housing Precarities. 


\section{LISTA DE TABELAS}

Tabela 1: Aumento de favelas entre 2010-2017 na RM de São Paulo ........................... 44

Tabela 2: Favelas recentes de acordo com seu tamanho em número de construções. 48

Tabela 3: Forma de ocupação das favelas recentes...................................................... 49

Tabela 4: Formação coletiva x responsáveis pelos lotes ................................................ 50

Tabela 5: Dinâmica de compra e venda de lotes nas favelas recentes ............................ 50

Tabela 6: Responsáveis pelos lotes nas favelas recentes.................................................50

Tabela 7: Material dos pisos das moradias nas favelas recentes .................................... 51

Tabela 8: Material predominante das paredes das moradias em favelas recentes........ 51

Tabela 9: Material predominante dos telhados das moradias em favelas recentes ......51

Tabela 10: Inserção das favelas recentes nos zoneamentos municipais ........................56

Tabela 11: Crescimento de construções em favelas recentes ao longo da década....... 57

Tabela 12: Fazendinha - Materialidade das moradias .................................................... 71

Tabela 13: Fazendinha - Relação de posse com os terrenos......................................... 72

Tabela 14: Fazendinha - Quantidade de dormitórios ................................................ 72

Tabela 15: Fazendinha - Abastecimento de água .......................................................... 72

Tabela 16: Fazendinha - Fornecimento de energia elétrica.......................................... 73

Tabela 17: Fazendinha - Esgotamento sanitário ........................................................... 73

Tabela 18: Fazendinha - Descarte de lixo ......................................................... 74

Tabela 19: Fazendinha - Autodeclaração de cor/etnia ................................................ 75

Tabela 20: Luiz Rubino - Materialidade das moradias ................................................ 78

Tabela 21: Luiz Rubino - Relação de posse com o terreno............................................ 80

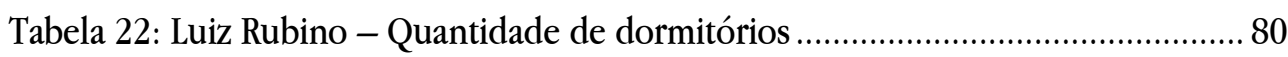

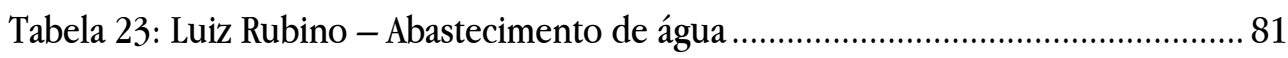

Tabela 24: Luiz Rubino - Fornecimento de energia elétrica....................................... 81

Tabela 25: Luiz Rubino - Esgotamento sanitário ..................................................... 81

Tabela 26: Luiz Rubino - Descarte de lixo .............................................................. 82

Tabela 27: Luiz Rubino - Autodeclaração de cor/etnia .................................................. 84

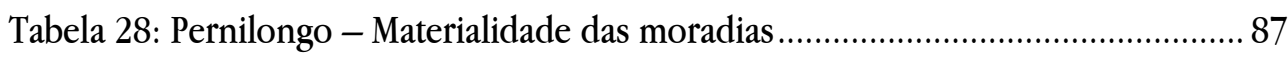

Tabela 29: Pernilongo - Relação de posse com o terreno ………………………....... 87

Tabela 30: Pernilongo - Quantidade de dormitórios por casa .................................... 88

Tabela 31: Pernilongo - Quantidade de cômodos por casa.......................................... 88

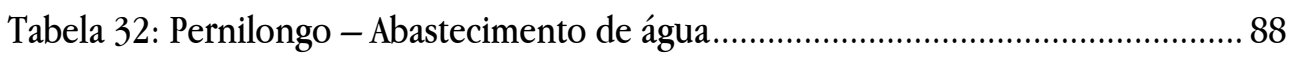

Tabela 33: Pernilongo - Fornecimento de energia elétrica........................................ 89

Tabela 34: Pernilongo - Esgotamento sanitário .......................................................... 89

Tabela 35: Pernilongo - Forma de descarte de lixo …………………......................... 89

Tabela 36: Pernilongo - Autodeclaração de cor/etnia ................................................... 91

Tabela 37: Olga Benário - Materialidade das moradias ............................................... 95

Tabela 38: Olga Benário - Relação de posse com o terreno .......................................... 96

Tabela 39: Olga Benário - Quantidade de dormitórios por casa ................................. 96

Tabela 40: Olga Benário - Abastecimento de água .................................................... 96 
Tabela 41: Olga Benário - Fornecimento de energia elétrica....................................97

Tabela 42: Olga Benário - Esgotamento sanitário ..................................................97

Tabela 43: Olga Benário - Descarte de lixo .......................................................98

Tabela 44: Olga Benário - Autodeclaração de cor/etnia ..............................................99

\section{LISTA DE ILUSTRAÇÕES}

Figura 1: Região Metropolitana de São Paulo - Divisão Sub-Regional ..........................45

Figura 2: Imagem de satélite da Região Metropolitana de São Paulo ............................45

Figura 3: Típica favela recente em Guarulhos .......................................................52

Figura 4: Localização das favelas definidas como estudos de caso na RMSP ................68

Figura 5: Fazendinha e o entorno imediato (raio de 500 metros) ...............................69

Figura 6: Imagens de satélite de Fazendinha de 2010 a 2017 ......................................69

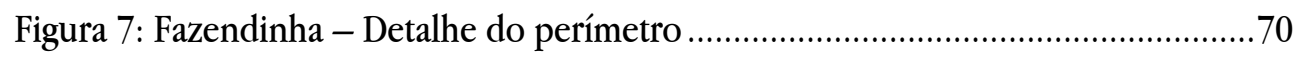

Figura 8: Fazendinha - Detalhe de vista interna de viela e córrego .............................70

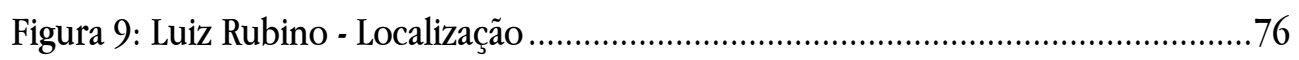

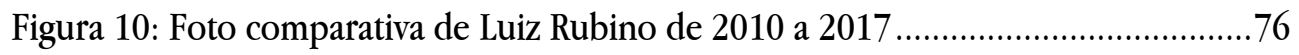

Figura 11: Luiz Rubino e o entorno imediato (raio de 500 metros) ................................77

Figura 12: Luiz Rubino - Vista do assentamento ...................................................

Figura 13: Luiz Rubino - Detalhe de moradia em madeira ........................................79

Figura 14: Pernilongo e o entorno imediato (raio de 500 metros) .................................84

Figura 15: Foto comparativa de Pernilongo de 2013 a 2017 ........................................85

Figura 16: Pernilongo - Vista de uma viela interna ...................................................86

Figura 17: Olga Benário e o entorno imediato (raio de 500 metros) ...........................92

Figura 18: Foto comparativa do terreno de Olga Benário de 2002 a 2017 ....................93

Figura 19: Olga Benário - Detalhe de vista da ocupação..............................................94

Figura 20: Olga Benário - Vista da via principal ......................................................94

\section{LISTA DE GRÁFICOS}

Gráfico 1: Domicílios em favelas ao longo das décadas em São Paulo ...........................28

Gráfico 2: Número de construções mapeadas por município ......................................46

Gráfico 3: Número de favelas recentes por município...............................................4 47

Gráfico 4: Materialidade das moradias em favelas recentes ............................................52

Gráfico 5: Crescimento do número de construções em favelas recentes ......................57

Gráfico 6: Pessoas em pobreza e pobreza extrema no Brasil (1992-2016) .....................58

Gráfico 7: Número de construções por ano na metrópole, no município de São Paulo

e em outros municípios.

Gráfico 8: Número de construções em ZEIS por ano na metrópole, no município de

São Paulo e em outros municípios

Gráfico 9: Número de construções exceto em ZEIS por ano na metrópole, no município de São Paulo e em outros municípios. 
Gráfico 10: Número de construções em favelas de iniciativa coletiva por ano na metrópole, no município de São Paulo e em outros municípios

Gráfico 11: Número de construções em favelas espontâneas por ano na metrópole, no município de São Paulo e em outros municípios

Gráfico 12: Número de construções em áreas de proteção ambiental por ano na metrópole, no município de São Paulo e em outros municípios ..................................... 63

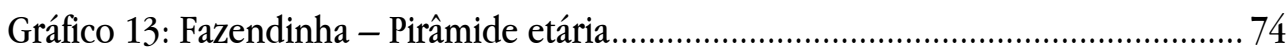

Gráfico 14: Fazendinha - Procedência dos moradores ................................................. 75

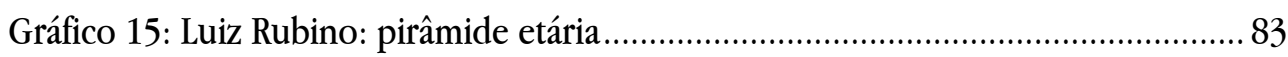

Gráfico 16: Luiz Rubino - Procedência dos moradores .............................................. 83

Gráfico 17: Pernilongo - Pirâmide etária .................................................................... 90

Gráfico 18: Pernilongo - Procedência dos moradores por unidade de federação....... 91

Gráfico 19: Olga Benário - Pirâmide etária ........................................................ 98

Gráfico 20: Olga Benário - Procedência dos moradores por unidade de federação ... 99

\title{
LISTA DE OUADROS
}

Quadro 1: Estudos de caso - aspectos gerais ........................................................... 100

Quadro 2: Estudos de caso - habitat e habitabilidade ................................................ 102

Quadro 3: Estudos de caso - perfil da população........................................................ 105

\section{LISTA DE SIGLAS}

IBGE - Instituto Brasileiro de Geografia e Estatística

EMPLASA - Empresa Paulista de Planejamento Metropolitano S/A

HIS - Habitação de Interesse Social

ONG - Organização não governamental

PNAD - Pesquisa Nacional por Amostra de Domicílio

\section{LISTA DE ABREVIATURAS}

\author{
APP - Área de preservação permanente \\ ECH - Encuesta de Caracterización de Hogares \\ ECS - Enquete de Caracterização Socioeconômica \\ hab/ha - habitantes por hectare \\ $\mathrm{m}^{2}-$ metros quadrados \\ $\mathrm{NA}$ - número absoluto \\ NS/NR - não sabe ou não respondeu
}




\section{SUMÁRIO}

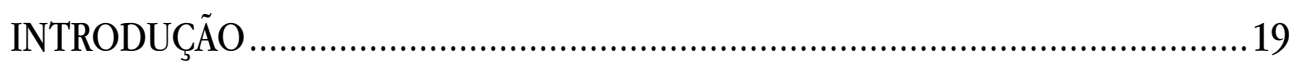

1. FAVELAS: ORIGENS E CARACTERIZAÇÃO ............................................23

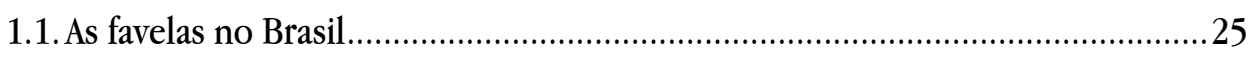

1.2. As favelas na metrópole de São Paulo...............................................................27

2. O QUE HÁ POR TRÁS DOS DADOS ........................................................31

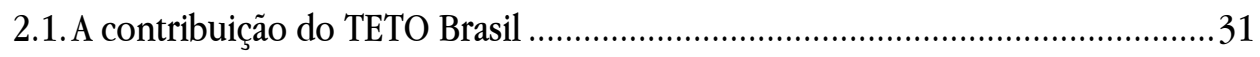

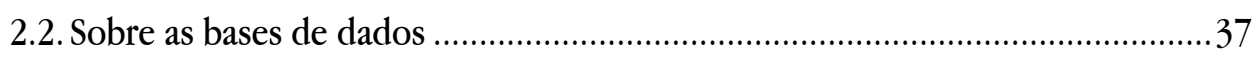

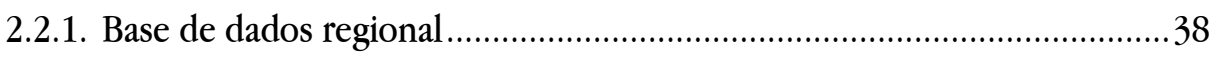

2.2.2. Base de dados comunitária........................................................................ 40

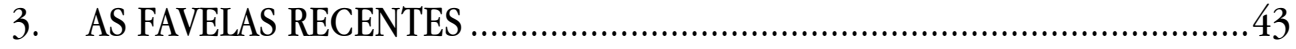

3.1. Distribuição regional por município ............................................................4 44

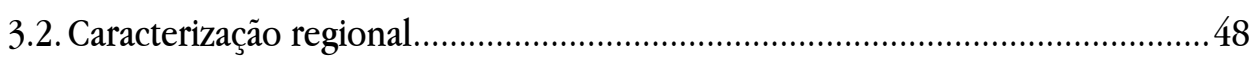

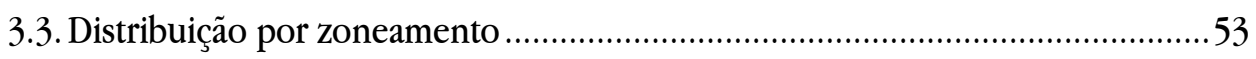

3.4. Aspectos cronológicos .................................................................................5

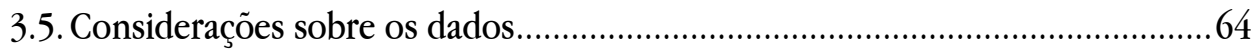

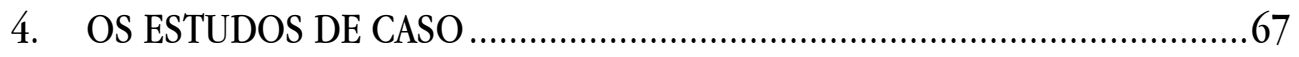

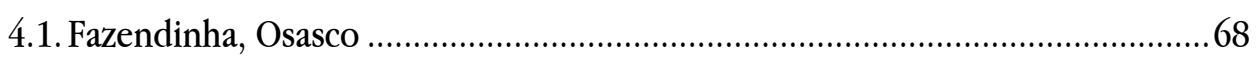

4.2. Luiz Rubino, São Paulo, Zona Leste ..................................................................75

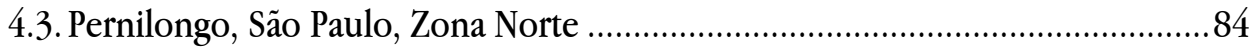

4.4. Olga Benário, São Paulo, Zona Sul ................................................................. 91

4.5. Considerações sobre os estudos de caso ...........................................................100

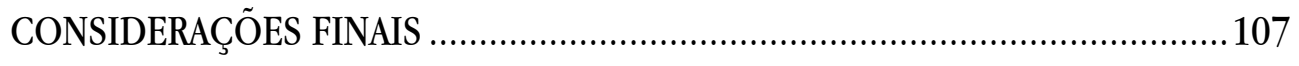

REFERÊNCIAS BIBLIOGRÁFICAS ............................................................. 111

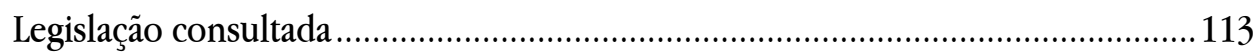

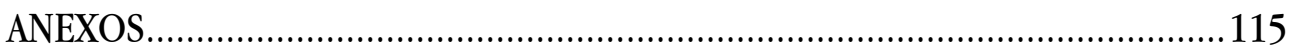





\section{INTRODUÇÃO}

As motivações iniciais desta pesquisa datam do ano de 2012, quando adentrei uma favela paulistana pela primeira vez. Dois aspectos me impressionaram de imediato: o tamanho e a precariedade da comunidade.

Inicialmente, me chamou a atenção a vastidão da área ocupada por casas de dois, três e até quatro pavimentos, construídas em alta densidade e em alvenaria, com aspecto inacabado e estrutura aparentemente insegura. Depois, no entanto, caminhando mais para dentro, visualizei uma favela bastante diferente: mais precária, com casas construídas de maneira improvisada a partir de restos de madeirite, em um ambiente extremamente insalubre, com forte cheiro de esgoto e muito lixo tomando conta de becos labirínticos.

Encarar a miséria de frente não era uma experiência nova para mim. Entretanto, como arquiteta, foi a primeira vez que pude vivenciar tão de perto as diferentes facetas da complexa problemática habitacional urbana.

A visita à favela Futuro Melhor, que descrevo acima, foi minha atividade de estreia como voluntária do TETO Brasil, organização social em que passei a trabalhar formalmente três anos mais tarde e na qual coordenei, por dois anos, as atividades de levantamento de informações em campo. No TETO, o "campo" são as favelas mais precárias, que abrigam pessoas em situação de extrema vulnerabilidade social.

Com o passar do tempo, a rotina de trabalho no TETO minimizou os sobressaltos diante das condições em que aquelas pessoas viviam. No entanto, um incômodo nunca me abandonou: por que justamente as favelas mais precárias não tinham visibilidade?

Se você for agora no Google Imagens e buscar a palavra "favela", encontrará o retrato perfeito da minha primeira visão do assentamento que visitei em 2012. Os resultados trarão as favelas densas, compostas por muitos andares em alvenaria, com uma extensão a se perder de vista na paisagem. São as 
conhecidas favelas dos morros do Rio de Janeiro, de Paraisópolis e Heliópolis, aquelas que se tornaram símbolos de décadas de lutas e resistência até chegarem ao estágio atual de consolidação.

Por outro lado, a outra favela, extremamente precária e insalubre, que muitas vezes se esconde por trás das construções em alvenaria, é um ambiente de muitos vazios e não-lugares. É uma favela que ainda não sabe o que é, que não tem identidade. As pessoas que vivem nela dificilmente conseguirão lutar por objetivos coletivos - antes, estão tentando sobreviver individualmente ou batalhando para conseguir alimentar os seus. Raramente existe apego por aquele espaço. O que se tem são sonhos de um dia morar num lugar melhor, porque estar ali é apenas provisório.

Foram muitas as histórias ouvidas nos seis anos de contato com o TETO Brasil. E ainda que, durante todo esse tempo, a organização buscasse dar visibilidade aos dados coletados nessas favelas, transformei esse desafio institucional em algo pessoal e me propus a estudar todo esse cenário com mais profundidade. Por isso, grande parte das informações aqui registradas foram presencialmente conferidas por mim e, portanto, representam mais do que números em tabelas, mas também um conhecimento empírico adquirido durante esse período.

Esta dissertação foi dividida em quatro capítulos. O primeiro foi reservado para a contextualização teórica acerca das origens e características das favelas no Brasil. É objetivo principal desse capítulo discutir os processos e dinâmicas que têm como consequência a formação das favelas, bem como a caracterização física das mesmas. Num segundo momento, o capítulo traz informações específicas sobre as favelas da metrópole de São Paulo, com o intuito de se aproximar do objeto de estudo.

O segundo capítulo diz respeito à metodologia da pesquisa e se divide em duas partes. Primeiramente, faz-se o relato da metodologia de levantamento de informações desenvolvida pelo TETO; em seguida, expõe-se a metodologia 
que permitiu a condução desta pesquisa a partir da base de dados já consolidada pela organização.

No terceiro capítulo, são apresentados os dados regionais em múltiplas frentes. A proposta passa por uma leitura da distribuição das favelas no território metropolitano; pela caracterização desses espaços mapeados; e pela abordagem da distribuição dos assentamentos nos zoneamentos municipais. Em seguida, são apresentadas, verificadas e analisadas informações sobre o aumento da quantidade de favelas a partir de uma perspectiva cronológica e do recorte temporal da pesquisa. Por fim, o capítulo se encerra com as principais considerações após a leitura de todos esses dados.

No quarto capítulo, os dados são apresentados em uma perspectiva mais aproximada, a partir de informações levantadas em campo, casa a casa. Informações sobre a caracterização socioespacial de quatro favelas diferentes são analisadas com o objetivo de encontrar semelhanças e divergências entre elas. $\mathrm{O}$ capítulo é encerrado com um resumo comparativo de cada um dos estudos de caso e com conclusões acerca das informações apresentadas.

No último capítulo, a partir do material abordado anteriormente, foram elaboradas as considerações finais com apontamentos dos temas de maior destaque da pesquisa, mas também trazendo questionamentos sobre a solução da problemática que envolve as favelas mais precárias. 
$22 \bullet$ favelas na metrópole de são paulo 


\section{FAVELAS: ORIGENS E CARACTERIZAÇÃO}

A palavra "favela" é originária da planta favela-branca, árvore típica das caatingas baianas e que inspirou o nome de Morro da Favella a uma encosta localizada no município de Monte Santo (BA), base das operações da Guerra de Canudos. No fim do século XIX, o Morro da Providência, no Rio de Janeiro, passou a ser chamado de Morro da Favela em função de sua ligação com a Guerra de Canudos. Segundo Valladares (2005), os antigos combatentes da guerrilha, ao voltar para a capital fluminense, se instalaram no local com a finalidade de pressionar o Ministério da Guerra a pagar seus soldos atrasados. E, embora a ocupação do Morro da Favela, ocorrida em 1897, não seja a primeira a acontecer no Rio de Janeiro, foi a que marcou um fato histórico brasileiro.

A nomenclatura foi tão marcante que, a partir de 1920, a palavra "favela" passou a servir não apenas para se referir ao Morro da Favella - tornou-se, então, um substantivo genérico para designar "aglomerações toscas que surgiam na cidade, geralmente em morros, e que eram construídas em terrenos de terceiros e sem aprovação do poder público". (ABREU, 1994)

As favelas de São Paulo, por sua vez, têm origem em meados da década de 1940, como consequência dos despejos ocorridos no centro da cidade, da política de higienização e da falta de alternativas habitacionais para as classes menos favorecidas. Bonduki (2011) aponta que esses primeiros núcleos de barracos precários, construídos em terrenos baldios próximos às regiões centrais e industriais, simbolizavam resistência do inquilinato despejado a se mudar para a periferia.

Ainda que tenham causado incômodo às elites na época, as favelas paulistanas só passaram a ser vistas pelo poder público como um problema a partir da década de 1970. Até então, a alternativa habitacional para grande parte da população de baixa renda era a autoconstrução em loteamentos periféricos, enquanto as favelas abrigavam apenas $1 \%$ da população. (BONDUKI, 2011) 
Após a década de 1970, a pobreza e a desigualdade social se intensificaram: houve crescimento econômico, mas também precarização e informalização das relações de trabalho, tornando uma parcela da população endividada e/ou com renda insuficiente para ter acesso ao mercado formal de habitação. Nesse momento, a favela passou a ser a principal alternativa para a parte da população que se enquadrava nas classes mais baixas. (CARDOSO, 2007)

Para Maricato (1996) esse grande número de pessoas em situação de ilegalidade habitacional é resultado de um processo de urbanização excludente que tem raízes históricas, amparado por uma sociedade com traços patrimonialistas e clientelistas. Em seu estudo "A terra é um nó na sociedade brasileira... também nas cidades", a autora definiu os motivos desse alto crescimento e os dispõe em três tópicos principais.

O primeiro ponto tem relação com o fato de a industrialização brasileira ter se dado com baixos salários: o custo habitacional não era considerado e o salário pago aos operários da indústria se tornava insuficiente para solucionar a questão da moradia dentro do mercado formal. Dessa forma, as alternativas possíveis se encontravam na favela ou no lote ilegal.

A autora também apontou uma tendência de os investimentos públicos alimentarem a especulação imobiliária em vez de democratizarem o acesso à terra para moradia. Isso ocorreu devido à dinâmica de poderes exercida pelos proprietários de terra e capitalistas ligados ao mercado imobiliário sobre os orçamentos municipais. Dessa forma, muitas vezes os investimentos públicos em infraestrutura são orientados para valorizar determinadas áreas em detrimento a outras, criando cidades cada vez mais segregadas do ponto de vista territorial.

O último ponto destacado está relacionado à legislação ambígua ou à aplicação arbitrária da lei. A autora defende que a ocupação de terras é tolerada pelo poder público, já que seu papel de fiscalização não tem sido exercido, exceto nos casos de áreas valorizadas pelo mercado.

Esse período foi marcado por uma intensa dinâmica de esvaziamento dos centros para as periferias, processo que criou vazios urbanos e fortaleceu a 
especulação imobiliária. A explosão da favelização se deu lado a lado com a expansão periférica, ocupando áreas desprovidas de qualquer infraestrutura, a partir da lógica da necessidade.

Outro ponto a ser destacado é o desenvolvimento físico desses espaços. Tal processo histórico se dá, inicialmente, pelo surgimento de modo muito precário dessas favelas e, posteriormente, pelas intervenções que são resultado de ações individuais e coletivas da população local ao longo dos anos. A favela passa pelo ciclo habitual de ocupação, autoconstrução e auto-urbanização até chegar no processo de consolidação dos assentamentos populares informais. (ABRAMO, 2009)

Mautner (1999) explica esse fenômeno por meio de uma sequência de três camadas. A primeira camada consiste em transformar as terras em propriedade, quando glebas são loteadas, terrenos são colocados à venda, algumas casas são construídas e é iniciado o processo de demanda por infraestrutura. O segundo momento é a chegada da infraestrutura e a consequente necessidade de adequação desses loteamentos à legislação vigente, o que geralmente não ocorre, culminando em uma legalização por meio de anistias. Entra, então, a terceira camada denominada "capital", quando, após muitos anos, essas áreas já possuem toda a infraestrutura urbana necessária para que possam ser vendidas a preços mais altos - elas configuram espaços irregulares, porém prontos para serem incorporados à cidade.

\subsection{As favelas no Brasil}

A informação relativa aos aglomerados subnormais segue sendo a única fonte de dados confiável e padronizada de abrangência nacional que permite quantificar as favelas no tecido urbano. O aglomerado subnormal é definido pelo Instituto Brasileiro de Geografia e Estatística (IBGE) como "um conjunto constituído de, no mínimo, 51 unidades habitacionais (barracos, casas, etc.) carentes, em sua maioria, de serviços públicos essenciais, ocupando ou tendo ocupado, até período recente, terreno de propriedade alheia (pública ou 
particular) e estando dispostas, em geral, de forma desordenada e/ou densa" ${ }^{1}$ (IBGE, 2010).

Considerando o aglomerado subnormal uma definição aproximada do que se considera favela, análises realizadas por Pasternak (2006) revelam o aumento exponencial do número de domicílios em favelas ao longo das décadas. As taxas de crescimento da população favelada foram sempre superiores às taxas da população total:

"Entre 1980 e 1991, os domicílios totais para o país cresceram 3,08\% ao ano, enquanto os favelados cresceram $8,18 \%$ anuais. No período seguinte - entre 1991 e 2000 - os domicílios totais aumentaram 3,05\% anuais, enquanto os favelados tiveram uma taxa de incremento anual de $4,18 \%$. A população favelada em 1980 alcançava 2,25 milhões de pessoas, a de 1991, mais de 5 milhões, e a do ano 2000, em torno de 7,2 milhões." (PASTERNAK, 2006)

No ano de 1991, o censo demográfico contabilizou mais de 3 mil aglomerados subnormais por todo o país, um número provavelmente subestimado $^{2}$, mas que já demonstrava a relevância das favelas nas regiões metropolitanas brasileiras. (IBGE, 1991)

Conforme apurado no último censo, 5,61\% da população brasileira habitavam favelas, o que representa 3,2 milhões de pessoas (IBGE, 2010). Por meio da leitura dos dados censitários realizada por Pasternak e D’Ottaviano (2016), é possível aferir um forte aumento dos aglomerados subnormais também na primeira década desse século. Entre os anos 2000 e 2010, enquanto a taxa

\footnotetext{
${ }^{1}$ Para identificar os aglomerados subnormais no tecido urbano, são considerados os seguintes critérios: "Ocupação ilegal da terra, e possuir pelo menos uma das seguintes características: urbanização fora dos padrões vigentes - refletido por vias de circulação estreitas e de alinhamento irregular, lotes de tamanhos e formas desiguais e construções não regularizadas por órgãos públicos; ou precariedade de serviços públicos essenciais, tais quais energia elétrica, coleta de lixo e redes de água e esgoto." (IBGE, 2011)

${ }^{2}$ A forma como o IBGE realiza a contagem do aglomerado subnormal pode causar distorções no número dessa população, pois se em um setor censitário houver 51 casas, todo o setor será considerado aglomerado subnormal, mesmo que as demais casas não possuam as mesmas características. Por outro lado, favelas pequenas, com menos de 51 casas precárias, não constarão na base de dados.
} 
anual de aumento de domicílios cresceu no Brasil a $0,57 \%$, a taxa para domicílios em aglomerados subnormais foi de $6,93 \%$, ou seja, razão 12 vezes maior.

No que diz respeito aos aspectos de infraestrutura, dados do censo de 2010 demonstraram que apenas 12\% dos aglomerados subnormais não eram abastecidos por água da rede pública, no entanto, só $56 \%$ tinham esgotamento sanitário regular. Já para a coleta de lixo, 76,4\% dos domicílios eram atendidos. No quesito energia elétrica, os dados apontavam que 96\% dos domicílios tinham acesso.

Tendo aglomerados subnormais do Brasil todo como referência, a densidade demográfica média calculada foi de 67,5 hab/ha. No total, 11 mil domicílios se localizavam em áreas contaminadas, quase 114 mil em faixas de domínio, mais de 27 mil sob linhas de alta tensão. Todos exemplos de áreas que não deveriam ter uso residencial por apresentarem risco à vida.

Enquanto 21\% dos aglomerados subnormais situavam-se em regióes com arruamento completo; quase $29 \%$ estavam em áreas com arruamento parcial e $7,5 \%$ ficavam em setores sem arruamento algum. No que se refere aos espaçamentos, $73 \%$ das favelas não apresentavam espaçamento nenhum entre as moradias.

\subsection{As favelas na metrópole de São Paulo}

A Região Metropolitana de São Paulo é que possui o maior número de favelas do Brasil, totalizando $27 \%$. Quanto ao número de habitantes em favelas, esse dado chega ultrapassar a marca de 2 milhões, o que representa 19\% da população total que vive em favelas no Brasil. Números que vêm aumentando desde 1991.

Segundo análises de Pasternak (2004) e Pasternak e D'Ottaviano (2016) a partir de dados censitários do IBGE, as taxas de crescimento de domicílios em favelas na metrópole paulistana foram mais elevadas que as da população no geral em todas as décadas. 
O gráfico a seguir confirma o contínuo crescimento do número de domicílios em assentamentos precários:

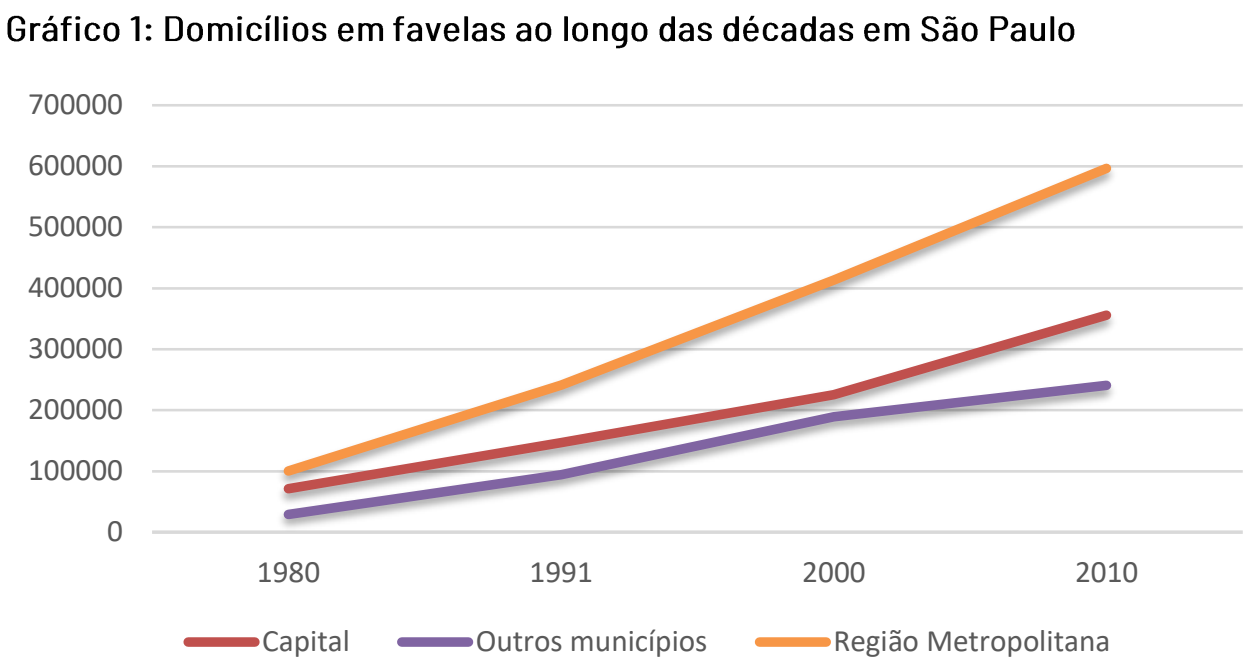

Fonte: Elaboração da autora a partir dos dados dos Censos de 1980, 1991, 2000 e 2010.

Os dados dos censos demográficos apontam que, no início da década de 1990, 5,72\% da população da Região Metropolitana de São Paulo habitava favelas, porcentagem que cresceu para $8,14 \%$ em 2000 e se manteve em crescimento, chegando a 9,79\% em 2010. De acordo com o último censo demográfico, a Região Metropolitana de São Paulo, composta por 39 municípios, atingiu 21,4 milhões de habitantes e, desse total, cerca de 2,1 milhões vivia em aglomerados subnormais.

Quanto à densidade demográfica, a região metropolitana de São Paulo apresentou 244,8 hab/ha, número que pode ser considerado alto, já que para a região Sudeste como um todo, a média foi de 99,1 hab/ha em 2010.

As altas densidades domiciliares são reflexo, em geral, da verticalização das unidades, embora, é claro, podem-se verificar altas densidades demográficas sem verticalização, sobretudo em assentamentos favelados, onde o espaçamento entre unidades, quanto existe, é pequeno. (PASTERNAK \& D’OTTAVIANO, 2016) 
Essa suposição se comprova quando olhamos para os dados relacionados à quantidade de pavimentos: $62 \%$ tinham dois ou mais, enquanto $37 \%$ eram térreos.

$\mathrm{O}$ espaçamento entre as moradias era quase inexistente, $85 \%$ das moradias levantadas não apresentavam nenhum espaçamento entre si, contribuindo para a formação de um ambiente denso, com poucas possibilidades de expansão horizontal. Tal fato explica a verticalização crescente desse tipo de assentamento.

Grande parte dos aglomerados subnormais se localizavam próximos a cursos d'água, somando quase $25 \%$ dos casos. 212 mil moradias se localizavam em regiões de encosta, 23 mil estavam em faixas de domínio, enquanto 2 mil ocupavam terrenos contaminados, número que reflete $18 \%$ do total no país.

Quanto ao arruamento nos aglomerados subnormais da metrópole paulistana, 33\% das moradias tinham acesso a ruas, enquanto um total de quase $60 \%$ só tinha acesso por meio de vielas.

A favela paulistana típica, em 2010, era composta por construções de mais de um pavimento, podiam ser considerados espaços mais densos se comparados ao restante da cidade. As moradias eram predominantemente de alvenaria e tinham, em média, 4 cômodos por domićlíio, sendo 2,24 pessoas por dormitório.

A maior parte das casas já acessava regularmente os serviços de fornecimento de energia elétrica e abastecimento de água. Em relação ao esgotamento sanitário, $67 \%$ das casas estavam ligadas à rede pública de esgoto, ou seja, mais de 30\% não apresentava despejo de dejetos adequado. Tais características aproximavam essa favela de uma unidade habitacional de baixa renda de qualquer loteamento formal.

Outro dado relevante destacado por Pasternak e D'Ottaviano (2016) diz respeito à faixa etária da população residente em favelas paulistanas, que é mais jovem se comparada ao restante do município. Também são majoritariamente pretos ou pardos, com $61 \%$ dos entrevistados, enquanto no município essa porcentagem era de $37 \%$. 
$30 \bullet$ favelas na metrópole de são paulo 


\section{O QUE HÁ POR TRÁS DOS DADOS}

A motivação inicial desta pesquisa tem relação direta com as atividades que envolviam o levantamento de informações da organização TETO Brasil. Para o entendimento do percurso metodológico, fez-se necessária, inicialmente, uma contextualização a respeito da instituição que entrou como fonte principal dos dados dessa pesquisa. Portanto, a primeira parte deste capítulo contempla a trajetória e amadurecimento da área responsável pelo levantamento de informações do TETO, além de trazer considerações a respeito das metodologias utilizadas para a coleta dos dados em campo.

Num segundo momento, o capítulo trata dos métodos utilizados para chegar na base de dados dessa pesquisa, a partir do recorte temporal estabelecido, além de definir os aspectos a serem analisados nas duas bases de dados utilizadas: a regional e a comunitária.

\subsection{A contribuição do TETO Brasil}

TETO (ou TECHO nos outros países) é uma organização nãogovernamental chilena, atuante no Brasil desde 2006, que desenvolve trabalho social em assentamentos, em sua maioria, urbanos, periféricos, recentes e extremamente precários. Seu programa mais conhecido é o de moradias de emergência que, por muitos anos, foi o único projeto realizado pela organização nas favelas do Brasil. O programa consiste, basicamente, na substituição de uma moradia precária e construída com materiais improvisados por uma casa de madeira pré-moldada de até $18 \mathrm{~m}^{2}$. O módulo é construído em dois dias e conta com a participação conjunta de moradores e voluntários.

No início da atuação do TETO no Brasil, as famílias beneficiadas pelo projeto eram escolhidas com base no interesse e na necessidade, aferidas de maneira subjetiva ou por meio de indicações. Em 2008, formou-se a equipe de Detecção e Designação, que viria a ser, mais tarde, a área responsável pelo levantamento de dados da organização. Nesse período, sua função era de 
determinar onde e com quem a organização poderia intervir, tendo como referência o programa de moradias de emergência. Com o passar do tempo, essa equipe foi aperfeiçoando sua metodologia e ferramentas de trabalho até que, em 2010, com o intuito de garantir a qualidade durante o processo de escolha das famílias, foi criado um formulário para avaliar a condição social, econômica e estrutural das famílias. A partir desse momento, os núcleos familiares deveriam ser priorizados com base numa pontuação proveniente do formulário, no interesse dos moradores pelo trabalho da organização e na percepção dos voluntários quanto à circunstância da família.

Nos anos seguintes, o volume de construções cresceu exponencialmente e, com ele, também a quantidade de informações levantadas em campo. E, embora, desde sempre, as pessoas que trabalhavam nessa equipe soubessem do valor e da dificuldade de se ter acesso a esses dados, não havia tempo hábil para sistematiza-los, e eles acabavam tendo uso apenas na seleção das famílias para o projeto das moradias.

O TETO continuou crescendo em São Paulo - tanto que, no ano de 2011, as construções foram desenvolvidas em todo o anel periférico da metrópole. No entanto, na escala latino-americana, a organização sentia necessidade de amadurecer o modelo de trabalho em campo e mudar o foco das moradias emergenciais para o de desenvolvimento comunitário. Afinal, só as construções não eram suficientes para alcançar a ambiciosa missão de "superar a pobreza através da formação e ação conjunta dos moradores e moradoras, jovens voluntários nas comunidades mais precárias" que a organização se propunha.

Sendo assim, as diretrizes do Escritório Internacional, a partir do ano de 2012, consistiam na entrada nos assentamentos precários e no desenvolvimento de um diagnóstico, no qual deveriam ser identificadas e caracterizadas as condições de vulnerabilidade dos mesmos. Posteriormente, como resposta às necessidades identificadas no diagnóstico, deveriam ser implementados os primeiros projetos, que poderiam ser referentes a habitabilidade, educação, trabalho, entre outros. Essas soluções deveriam ser desenvolvidas por meio de 
um trabalho conjunto entre voluntários e moradores, potencializando capacidades individuais e coletivas de autogestão na comunidade.

A mudança institucional tardou a ser processada no Brasil. Os primeiros efeitos só começaram a ser sentidos em 2013. Uma das mudanças ocorridas foi o desmembramento das áreas de Detecção e Designação e de Construções. A partir desse momento, a atuação delas não estava mais restrita apenas a dar apoio para o programa de moradias. Agora, também assumiam duas responsabilidades principais: implementação e consolidação do trabalho em campo e produção de informação para a tomada de decisões da organização. Nesse mesmo ano, o Escritório Internacional apresentou aos países o que passou a ser a ferramenta principal para levantamento de informações a nível latino-americano: a Encuesta de Caracterización de Hogares (ECH), que foi traduzida pela equipe brasileira como Enquete de Caracterização Socioeconômica ${ }^{3}(\mathrm{ECS})$, formulário que se assemelha muito ao desenvolvido pelo IBGE para os levantamentos do censo brasileiro. Cada vez mais, a organização dava passos na direção de profissionalizar e transformar os dados que levantava em informações confiáveis. Também era um objetivo importante que esses dados pudessem ter desdobramentos externos à organização e contribuíssem em para a construção de políticas públicas.

Em 2015, assumi a direção da área até então denominada Detecção e Designação que, a partir da minha entrada, passou a se chamar Diagnóstico e Avaliação. Nesse período, a diretriz da organização era expandir as atividades em campo: tanto em trabalho contínuo, de desenvolvimento comunitário, quanto pontual, de construções de moradias emergenciais. Dessa forma, cabia à área de Diagnóstico e Avaliação encontrar favelas com o perfil de precariedade que o TETO se propunha a trabalhar, além de fazer um diagnóstico socioeconômico daquelas que haviam sido selecionadas para dar início à atuação.

\footnotetext{
${ }^{3}$ Modelo disponível nos anexos deste documento.
} 
A área era composta por três equipes: Diagnóstico Regional, responsável pela busca de novas comunidades em escala regional; Diagnóstico Comunitário, responsável pelos diagnósticos socioeconômicos em escala comunitária; e Mapeamento, responsável pela produção de mapas que apoiavam o levantamento dos dados relativos a diagnóstico comunitário.

A busca por novos assentamentos com o perfil de trabalho era executada em algumas etapas. Primeiramente, voluntários eram capacitados e divididos em regiões diferentes para localizar possíveis favelas por meio de observação de imagens de satélite. A orientação era de que deveriam ser priorizadas as mais precárias, e nem sempre era possível definir, a partir dessas imagens, se um assentamento era ou não precário. Porém, a irregularidade do traçado viário, a forma desordenada de disposição das moradias, a inexistência de pavimentação das vias, o tempo de início de ocupação observado pela comparação de imagens de anos anteriores, entre outros aspectos, poderiam sugerir o grau de consolidação de um determinado assentamento. Sendo assim, a capacitação dos voluntários consistia em instruí-los a respeito dessas características, de forma que a busca acontecesse da maneira mais eficiente possível.

Ao se deparar com um aglomerado de casas que apresentasse alguns desses aspectos, o voluntário fazia uma marcação em mapas virtuais e preenchia o endereço numa planilha de controle. Depois, numa segunda etapa, o coordenador da equipe de Diagnóstico Regional, geralmente voluntário com maior experiência, revisava todas as marcações realizadas pelos voluntários da equipe e organizava as favelas marcadas em grupos de três ou quatro, de acordo com a sua proximidade geográfica. A terceira etapa consistia em visitar esses lugares e preencher uma ficha denominada "Perfil de Comunidades" ${ }^{4}$ com as informações que, geralmente, eram cedidas por um líder comunitário ou morador que tivesse conhecimento sobre a maioria dos aspectos da comunidade.

\footnotetext{
${ }^{4}$ Modelo disponível nos anexos deste documento.
} 
Vale destacar que esses dados eram levantados de maneira massiva, em sua maioria, e as visitas aconteciam num único fim de semana. $\mathrm{E}$, para isso, eram organizados eventos, os chamados Mutirões de Visitas, que concentravam visitas numa região diferente da metrópole de São Paulo. Cada Mutirão de Visita contava com aproximadamente 50 voluntários que conseguiam visitar e levantar, a cada fim de semana, informações de aproximadamente 50 favelas.

O trabalho da coordenação de Diagnóstico Regional era finalizado quando o Mutirão de Visitas se encerrava e as informações coletadas eram tabuladas e registradas em planilhas. O ciclo se reiniciava quando outra região era definida para ser visitada. Até o fim do ano de 2017, haviam sido levantadas informações de cerca de 300 favelas em toda a metrópole de São Paulo.

O passo seguinte era definir quais seriam as favelas em que o TETO daria início aos seus projetos. Primeiramente, eram analisadas as características físicas do assentamento com base nas informações preenchidas nas fichas e por meio das fotos tiradas do local. Num segundo momento, a liderança comunitária era contatada por telefone para agendar o que chamávamos de "visita de validação". Essa segunda visita, geralmente realizada por mim, consistia em confirmar as informações que haviam sido levantadas previamente, principalmente no que dizia respeito à precariedade e às necessidades locais, bem como entender se havia interesse, por parte da comunidade, nos projetos que a organização tinha a oferecer. E, uma vez que ambas as partes estivessem de acordo, era dado início ao trabalho de fato.

Como já mencionado, as diretrizes de trabalho eram de que, antes que projetos fossem executados na comunidade, se realizasse um diagnóstico para identificar e caracterizar as condições de vulnerabilidade de cada um dos assentamentos. E era nesse momento que entravam as duas outras coordenações: Mapeamento e Diagnóstico Comunitário.

A equipe de Mapeamento era responsável por levantar o número de moradias total que fariam a composição do universo de casas a ser considerado para a realização do diagnóstico socioeconômico. O voluntário responsável pelo 
mapa recebia uma capacitação prévia e entrava em campo para dar início ao desenho. Quase sempre os "mapeadores" eram estudantes de cursos de Arquitetura e Urbanismo que já dominavam técnicas de desenho.

Com a imagem de satélite do assentamento impressa em mãos, já tinham uma base aproximada do formato da comunidade, da largura de vias, do adensamento e do número de casas. Passavam de rua em rua, beco em beco, contabilizando e desenhando as casas e depois, com esse mapa pronto, realizavam uma numeração. Com base nela, definiam a quantidade de voluntários necessária para a realização do levantamento de informações de todas as casas.

No fim de semana do levantamento de informações, equipes de voluntários eram divididas por zonas e cada uma delas era liderada por um voluntário mais experiente e previamente capacitado para a aplicação da já mencionada Enquete de Caracterização Socioeconômica. A capacitação para aplicação da ECS, posterior revisão e compatibilização dos dados provenientes da mesma era de responsabilidade da equipe de Diagnóstico Comunitário.

Durante o fim de semana de realização do evento chamado "Escutando Comunidades", voluntários batiam de porta em porta, apresentando o trabalho da organização e aplicando o questionário. Eventualmente, ocorriam recusas por parte dos moradores, mas na maior parte das vezes eram receptivos e respondiam às questões de maneira aberta.

No ano de 2015, o formulário aplicado era em papel, o que exigia posterior tabulação das informações coletadas e esse processo manual tornava a base de dados mais suscetível a erros. No entanto, a partir do ano de 2016, as entrevistas já foram realizadas por meio de um aplicativo, o que tornou a pesquisa ainda mais confiável devido a um maior número de respostas fechadas e à automaticidade que o sistema proporcionava, não necessitando realizar a tabulação manual das informações.

Outra tecnologia que favoreceu o levantamento de informações foi o uso de drones no ano de 2017. Esses equipamentos permitiram à equipe de 
mapeamento ter acesso a imagens aéreas mais recentes e de maior qualidade, o que facilitou muito o trabalho dos mapeadores e tornou os mapas mais fidedignos à realidade.

A motivação em fazer uso dos dados de forma estratégica dentro do TETO aconteceu após 2015 e demandou um grande esforço tanto para mobilizar pessoas voluntárias interessadas em trabalhá-los, quanto na articulação de outras entidades que pudessem vir a utilizar esses dados para fins externos à organização. Em outros países, como Argentina e Chile, os dados da instituição ficam disponíveis em plataformas virtuais, são consultados publicamente e constituem referência nacional na temática de pobreza desses países.

No Brasil, a preocupação dos últimos anos de quem esteve à frente da área de Diagnóstico e Avaliação foi em, primeiramente, conquistar reconhecimento e valor dentro da própria organização, consolidar os processos, garantir a qualidade dos dados levantados e manter a base atualizada para, posteriormente, disponibilizá-la para consulta pública.

Conhecer a realidade para incidir em políticas públicas era um dos objetivos estratégicos do TETO, e a equipe caminhava para esse fim. Infelizmente, em 2018, foram realizados cortes orçamentários na organização e, até a data de publicação desta pesquisa, a área de Diagnóstico e Avaliação já não contava mais com uma pessoa contratada para fazer a gestão dos voluntários e dos projetos mencionados.

\subsection{Sobre as bases de dados}

Como mencionado, foram utilizadas duas bases de dados provenientes da organização TETO Brasil coletadas a partir de dois questionários diferentes e em escalas de abrangência distintas. A primeira base é composta pelos levantamentos realizados nas visitas pontuais, denominada base de dados regional; a segunda, denominada base de dados comunitária, é formada pelos levantamentos socioeconômicos realizados com todos os moradores de cada assentamento. 
Para esta dissertação, foi definido o recorte temporal de período posterior a 2010, tendo em vista que o último censo demográfico é relativo a esse ano e é a base mais atual considerando dados oficiais a nível metropolitano. Estudar favelas posteriores a esse período seria apresentar informações inéditas e com alto potencial de contribuição na comunidade acadêmica. Dessa forma, todas as favelas apresentadas neste estudo surgiram ou apresentaram expansão horizontal após 2010 e foram denominadas "favelas recentes".

A forma como cada base de dados foi trabalhada para compor o estudo será apresentada nos tópicos a seguir.

\subsubsection{Base de dados regional}

Como mencionado, a base de dados regional do TETO dispunha de informações de mais de 300 favelas localizadas em toda metrópole de São Paulo. No entanto, haviam sido catalogadas em fichas físicas de formatos diferentes e nem todas estavam tabuladas digitalmente. Dessa forma, o trabalho inicial foi de organizar tais documentos.

Com o recorte temporal definido, num primeiro momento foi necessário realizar a seleção daquelas que fariam parte do conjunto a ser analisado e, para isso, foram escolhidas somente as que demonstravam surgimento e/ou crescimento em imagens de satélite a partir do ano de 2010. Tal observação foi realizada utilizando o software Google Earth, por meio da ferramenta de regressão histórica das imagens, e foi concluída nos primeiros meses do ano de 2018, portanto é importante ressaltar que os dados das favelas aqui apresentados tiveram surgimento e/ou expansão territorial entre os anos de 2010 e 2017.

Também vale destacar que, durante o processo de filtragem, foram observadas nas adjacências outras favelas surgidas no período estudado, mas que não estavam contempladas na base de dados existente. Ao final do processo, as novas favelas descobertas somadas às favelas filtradas da base de dados original alcançaram um total de 117 favelas recentes mapeadas. 
Já com as favelas definidas a compor o banco de dados, foi necessária a compatibilização das informações coletadas, pois ao longo dos anos o formulário de coleta sofreu modificações. Sendo assim, a organização dos dados foi feita de forma a ficarem todas as informações concentradas numa única tabela. $\mathrm{O}$ mapeamento dessas favelas encontrava-se no formato kml (extensão do Google Earth) que foi convertido para shapefile e vinculado com a planilha de dados através do software QGis, onde seria possível elaborar mapas temáticos utilizando a base de dados.

Com o banco de dados finalizado e conectado aos pontos georreferenciados, as dúvidas giravam em torno de quais temáticas explorar, visto que a quantidade de informações era grande, mas que nem todas apresentariam resultados que fossem considerados relevantes do ponto de vista acadêmico. Algumas possibilidades foram apresentadas no memorial de qualificação e após a apresentação na banca e do debate envolvendo as professoras presentes, foram definidas as características a serem analisadas:

a) forma como se deu a ocupação, se espontânea por meio de iniciativas individuais ou se coletiva e organizada com a intervenção de movimentos sociais ou outros agentes;

b) tamanho em número de construções;

c) relação interna de compra e venda de lotes;

d) materialidade das construções;

e) inserção dos assentamentos nos zoneamentos municipais;

f) número de construções por assentamento contabilizadas ano a ano;

As informações das três primeiras características listadas são provenientes da base de dados do TETO e, portanto, são dados autodeclarados de líderes comunitários ou outros moradores. Além disso, nem todas as 117 favelas possuem tais dados, sendo variado o número amostral de cada uma das informações. 
Por outro lado, o número de construções foi contabilizado por meio de observação de imagens de satélite. Foi estimado, ano a ano, a partir da ferramenta de regressão histórica de imagens do Google Earth a quantidade de construções, permitindo assim uma análise cronológica do crescimento de favelas na metrópole paulista. Tal processo foi realizado igualmente para as 117 favelas recentes mapeadas e organizado na planilha da base de dados regional.

A característica que diz respeito à inserção nos zoneamentos municipais foi detectada a partir da sobreposição da geolocalização das favelas sobre os mapas de zoneamento de cada um dos municípios. Da mesma forma, essas informações foram adicionadas à planilha e, posteriormente, para fins analíticos, agrupadas em seis categorias: (i) áreas de proteção ambiental, (ii) zonas especiais de interesse social, (iii) zonas de desenvolvimento econômico, (iv) zonas industriais, (v) zonas mistas e (vi) outros.

Desde o início, a proposta desta pesquisa era de ir além dos dados quantitativos dispostos em tabelas. Portanto, foi dado um enfoque, sempre que possível, para análises espaciais por meio de mapas temáticos com as características citadas anteriormente, além de gráficos, no caso das informações temporais, que permitiram comparações em busca de padrões.

\subsubsection{Base de dados comunitária}

A base de dados comunitária é proveniente dos levantamentos de dados realizados por meio da Enquete de Caracterização Socioeconômica que, dentro do modelo de trabalho da organização TETO, tem como objetivo obter informação sobre a situação das comunidades antes do início da intervenção, a fim de servir de insumo tanto para o planejamento do trabalho conjunto entre as comunidades e a organização, quanto para a efetiva relação com outros atores da sociedade, como entidades governamentais, empresas e/ou outras instituições.

Para a definição dos estudos de caso, foram consideradas duas variáveis: o ano de formação - que necessariamente precisava ser posterior a 2010 - e o 
modo que se formou o assentamento. Nesse caso, a ideia era apresentar duas favelas com ocupação espontânea e duas de formação coletiva. Também foram consideradas favelas de diferentes regiões da metrópole de São Paulo: uma em Osasco, outras três no município de São Paulo, uma na zona leste, uma na zona norte, e a última na zona sul. Por questões de confiabilidade das informações, foram considerados levantamentos de dados feitos mais recentemente, ou seja, aqueles que haviam sido coletados após 2016.

Aas informações definidas para serem analisadas nessa pesquisa foram:

a) materialidade das moradias;

b) relação de posse com o terreno (se próprio, alugado, emprestado, etc);

c) tamanho das moradias, por metro quadrado, quantidade de cômodos e quantidade de dormitórios;

d) infraestrutura;

e) densidade habitacional;

f) relação com a posse (se a moradia é alugada, própria, cedida, etc);

g) pirâmide etária da população residente;

h) autodeclaração de cor ou etnia;

i) procedência (unidade da federação de nascimento). 
42 • favelas na metrópole de são paulo 


\section{AS FAVELAS RECENTES}

Como mencionado no capítulo anterior, os dados aqui dispostos são resultado de um extenso trabalho de campo e, posteriormente, da tabulação e análise dos mesmos. Tais informações foram levantadas favela por favela ao longo dos anos de 2015, 2016 e 2017 por centenas de voluntários, o que permitiu a consolidação, ao final de 2017, de uma base de dados de mais de 300 assentamentos. Para esse estudo, foram filtradas apenas aquelas que haviam surgido ou se expandido territorialmente a partir do ano de 2010, denominadas aqui de favelas recentes.

A base de dados regional que será apresentada neste capítulo é composta por informações de 117 favelas recentes que foram abordadas a partir de quatro diferentes perspectivas. Num primeiro momento, buscou-se contextualizar o leitor acerca da distribuição regional dessas favelas dentro da metrópole de São Paulo, destacando o protagonismo de alguns municípios em detrimento a outros. Em seguida, foi elaborada uma leitura das principais características físicas e dinâmicas inerentes ao surgimento desses espaços. Na sequência, foi realizada uma abordagem territorial a partir da sobreposição dos zoneamentos de cada município. E, por último, foram apresentados padrões e tendências de acordo com o recorte temporal do estudo, que se inicia em 2010 e finaliza em 2017.

O capítulo é encerrado com as principais conclusões extraídas a partir da análise dos dados apresentados. 


\subsection{Distribuição regional por município}

Para uma contextualização inicial, foram relacionadas as informações de todos os municípios da Região Metropolitana de São Paulo com aglomerados subnormais detectados em 2010 e comparadas com as informações do banco de dados regional consolidado em 2017 para esta pesquisa.

No levantamento do IBGE, foram contabilizados 24 municípios, 3246 aglomerados subnormais e 596.479 domicílios. Já a base de dados regional de favelas recentes contou com 14 municípios, 117 novas favelas e 38.813 novas construções.

Tabela 1: Aumento de favelas entre 2010-2017 na RM de São Paulo

\begin{tabular}{|c|c|c|c|c|c|c|}
\hline & \multicolumn{2}{|c|}{2010} & \multicolumn{2}{|c|}{2017} & \multicolumn{2}{|c|}{ Aumento ${ }^{5}(\%)$} \\
\hline & Aglomerados & Domicílios & Favelas & Construções & Favelas & Domicílios \\
\hline RM de São Paulo & 3246 & 596479 & 117 & 38813 & 3,60 & 6,51 \\
\hline Barueri & 6 & 669 & 0 & 0 & 0,00 & 0,00 \\
\hline Caieiras & 6 & 670 & 0 & 0 & 0,00 & 0,00 \\
\hline Cajamar & 3 & 796 & 0 & 0 & 0,00 & 0,00 \\
\hline Carapicuíba & 39 & 7724 & 6 & 1110 & 15,38 & 14,37 \\
\hline Cotia & 3 & 352 & 0 & 0 & 0,00 & 0,00 \\
\hline Diadema & 131 & 24616 & 0 & 0 & 0,00 & 0,00 \\
\hline Embu das Artes & 56 & 8967 & 2 & 450 & 3,57 & 5,02 \\
\hline Ferraz de Vasconcelos & 21 & 3102 & 3 & 640 & 14,29 & 20,63 \\
\hline Francisco Morato & 27 & 2365 & 0 & 0 & 0,00 & 0,00 \\
\hline Franco da Rocha & 18 & 2522 & 0 & 0 & 0,00 & 0,00 \\
\hline Guarulhos & 305 & 57653 & 11 & 2700 & 3,61 & 4,68 \\
\hline Itapecerica da Serra & 3 & 388 & 1 & 80 & 33,33 & 20,62 \\
\hline Itapevi & 4 & 851 & 0 & 0 & 0,00 & 0,00 \\
\hline Itaquaquecetuba & 35 & 7412 & 1 & 150 & 2,86 & 2,02 \\
\hline Jandira & 2 & 578 & 2 & 150 & 100,00 & 25,95 \\
\hline Mauá & 101 & 22894 & 4 & 810 & 3,96 & 3,54 \\
\hline Osasco & 124 & 21505 & 4 & 1650 & 3,23 & 7,67 \\
\hline Ribeirão Pires & 4 & 892 & 0 & 0 & 0,00 & 0,00 \\
\hline Santana de Parnaíba & 2 & 1100 & 0 & 0 & 0,00 & 0,00 \\
\hline Santo André & 111 & 23806 & 3 & 380 & 2,70 & 1,60 \\
\hline São Bernardo do Campo & 197 & 43072 & 2 & 520 & 1,02 & 1,21 \\
\hline São Paulo & 1998 & 355756 & 75 & 29833 & 3,75 & 8,39 \\
\hline Suzano & 17 & 1438 & 2 & 210 & 11,76 & 14,60 \\
\hline Taboão Da Serra & 33 & 7351 & 1 & 140 & 3,03 & 1,90 \\
\hline
\end{tabular}

Fonte: Elaborado pela autora a partir do Censo (2010), TETO BRASIL (2017) e Google Earth (2017).

\footnotetext{
${ }^{5}$ Não é possível afirmar que todas as novas construções mapeadas via imagem de satélite configuram domicílios, pois algumas podem estar vazias, aguardando serem ocupadas, numa espécie de dinâmica de especulação imobiliária muito comum em favelas recentes. Portanto, há que se considerar que o cálculo do aumento domiciliar pode estar superestimado.
} 
Figura 1: Região Metropolitana de São Paulo - Divisão Sub-Regional

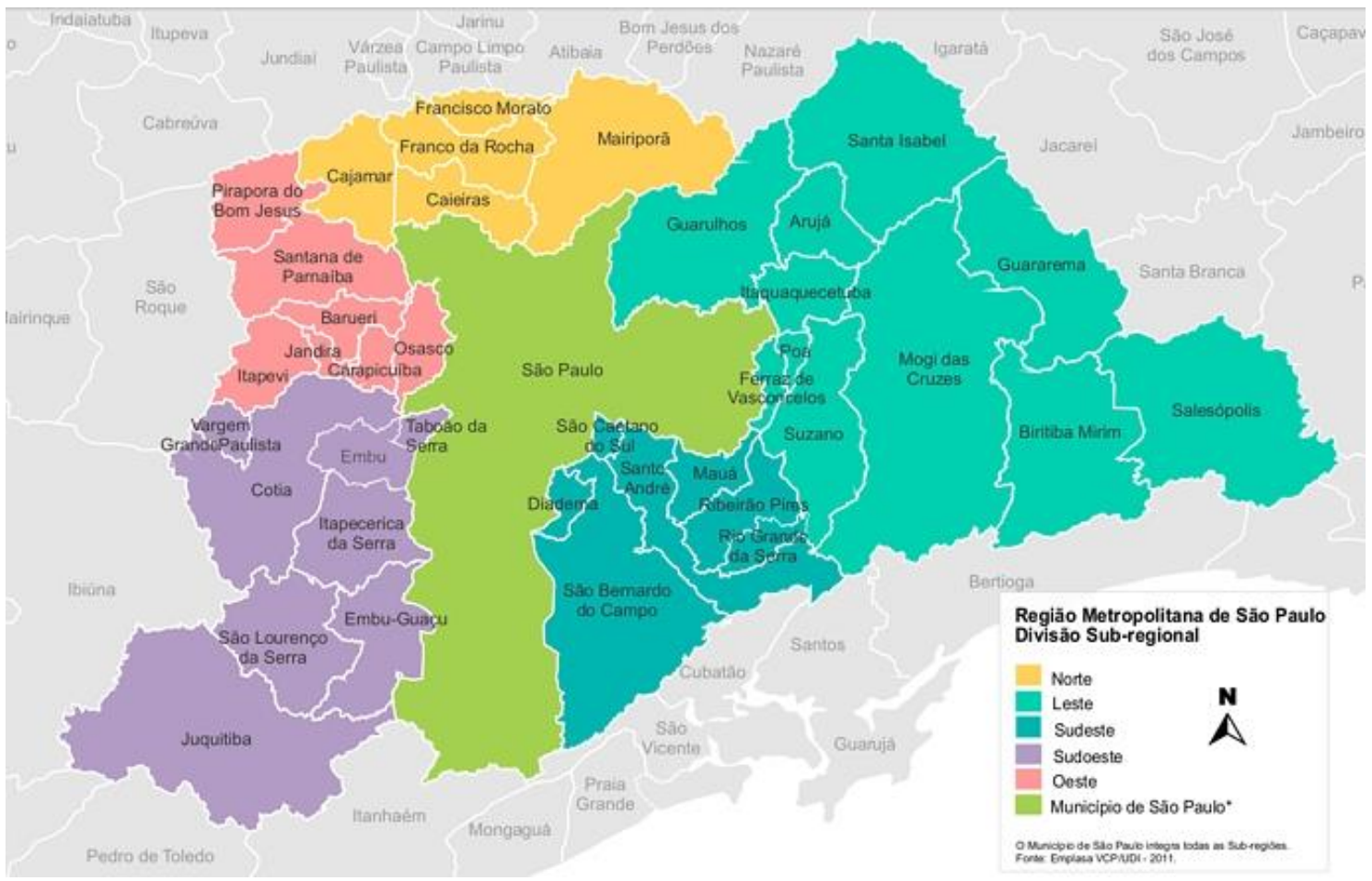

Fonte: Emplasa

Figura 2: Imagem de satélite da Região Metropolitana de São Paulo

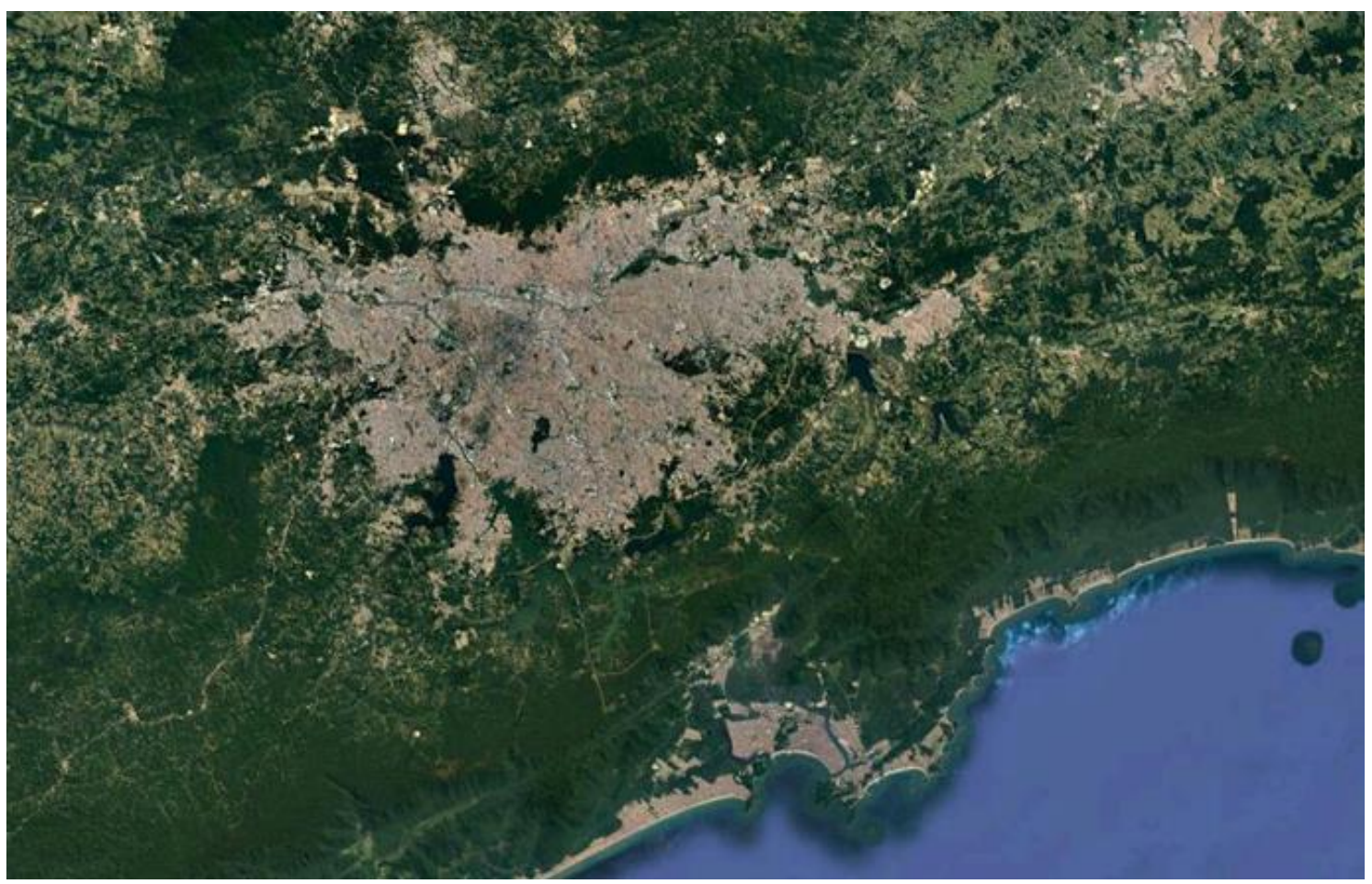

Fonte: Google Earth 
Os números mais significativos, quando comparados aos dados de 2010, ocorreram nos municípios de Jandira com quase 26\% de aumento de domicílios em favelas, e em Ferraz de Vasconcelos e Itapecerica da Serra, com 20\% cada. Também tiveram destaque os municípios de Carapicuíba e Suzano, com 14\% cada, São Paulo, com 8\%, e Osasco, com 7\%.

Uma surpresa foi a região do $\mathrm{ABC}$, a sul da capital, que historicamente teve formação de favelas em grande quantidade em seus territórios, mas que no período estudado apresentou números baixos de novos assentamentos. Diadema não registrou nenhuma nova favela e os municípios de São Bernardo do Campo e Santo André não chegaram a registrar nem $2 \%$ de aumento de novas construções em favelas.

Gráfico 2: Número de construções mapeadas por município

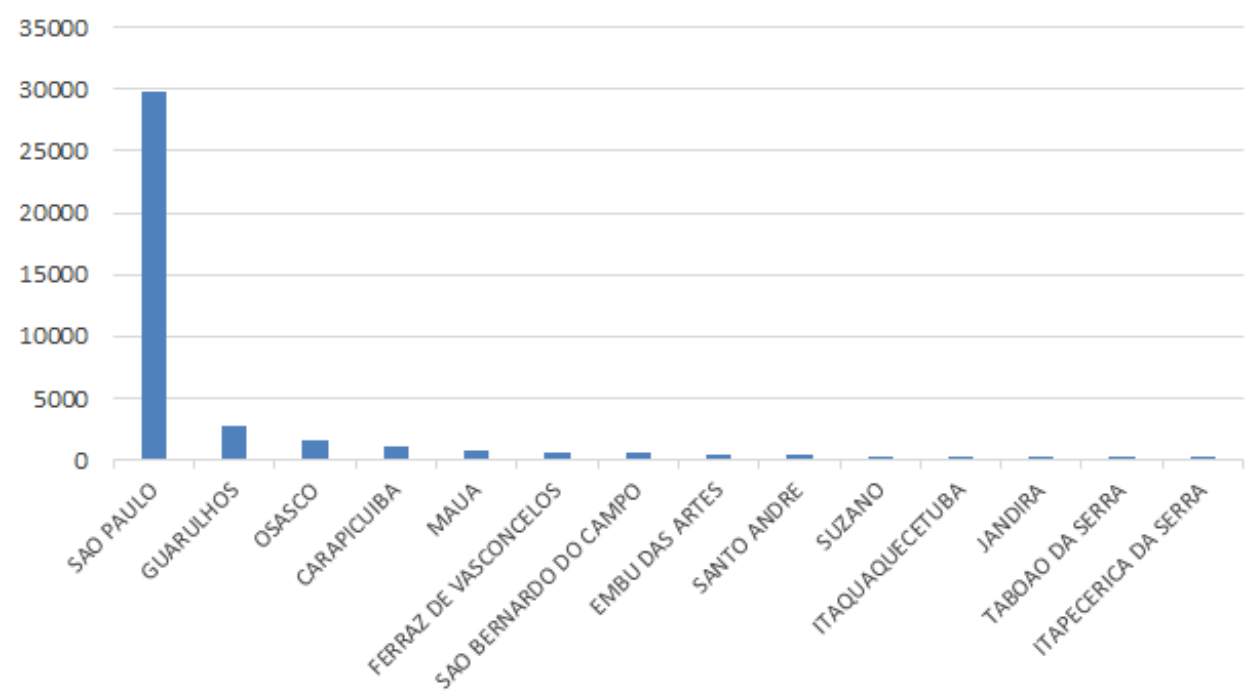

Fonte: Elaboração da autora a partir de dados do TETO BRASIL $(2015,2016$ e 2017)

Em se tratando de números absolutos, o município de São Paulo foi o que mais teve favelas contabilizadas em seu tecido urbano, com um total de $\mathbf{7 5}$, o que representou 64\% do todo; Guarulhos, o segundo maior município da região, apresentou 11, totalizando aproximadamente $9 \%$ de favelas recentes. Os demais municípios apresentaram números mais baixos, com variações de 1 a 5\% do resultado total. 
Gráfico 3: Número de favelas recentes por município

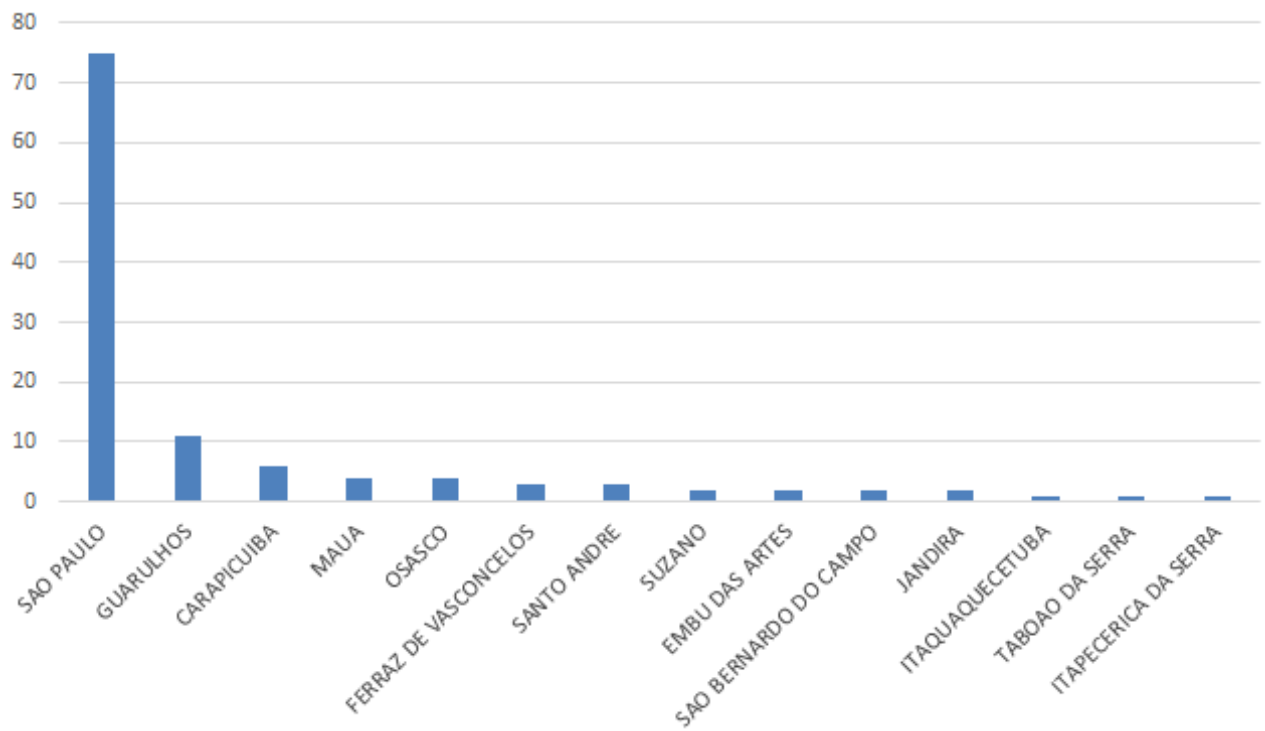

Fonte: Elaboração da autora a partir de dados do TETO BRASIL (2015, 2016 e 2017)

Mapa 1: Localização das favelas recentes na metrópole de São Paulo

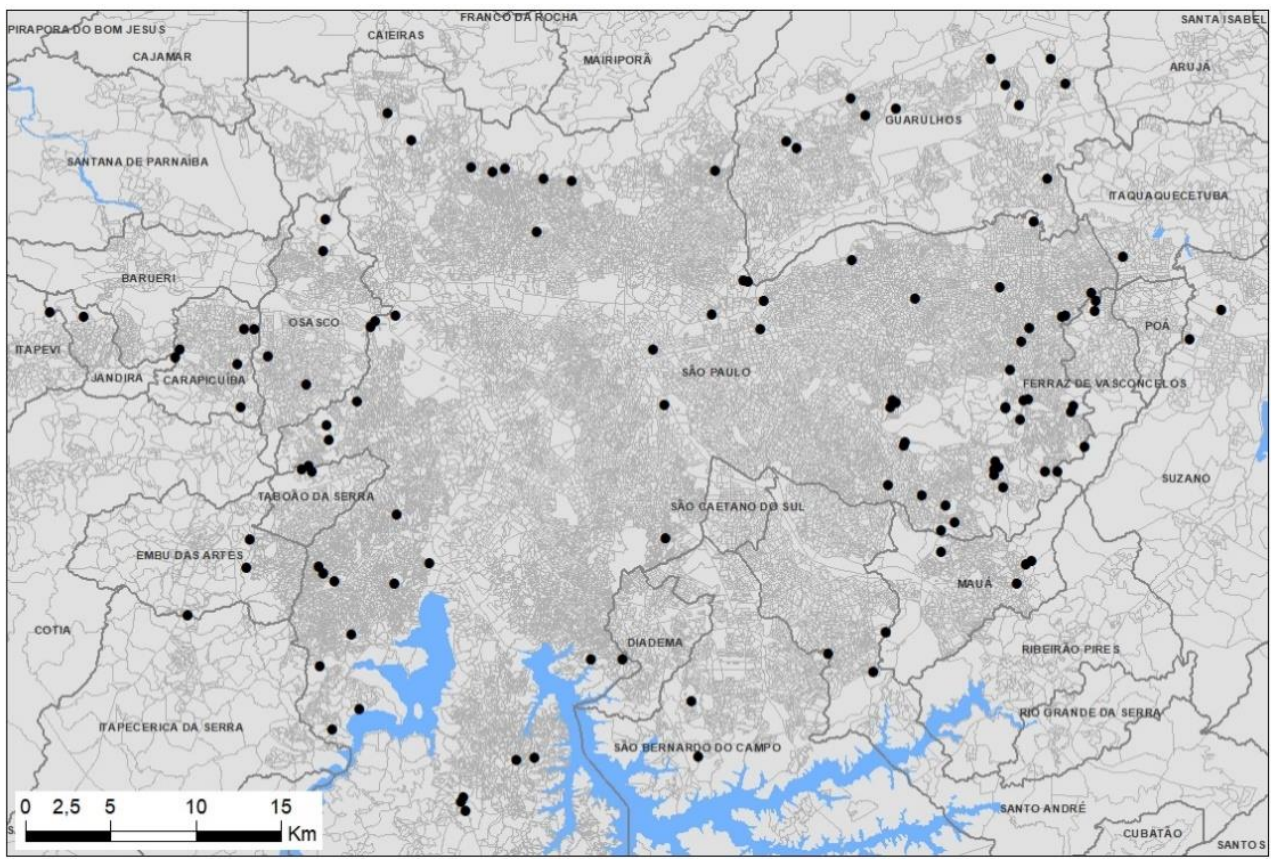

Fonte: Elaboração da autora

As 117 favelas mapeadas se localizavam, prioritariamente, nas áreas mais periféricas da conurbação urbana de São Paulo. A zona que mais apresentou concentração de favelas recentes foi a Zona Leste de São Paulo e municípios adjacentes - Itaquaquecetuba, Suzano, Ferraz de Vasconcelos e Mauá -, com um total de 48 favelas. Nota-se também uma considerável concentração de novos 
núcleos na região oeste da capital e dos municípios próximos - Carapicuíba, Embu das Artes, Osasco e Taboão da Serra -, totalizando 27 favelas nessas localidades. Outra observação relevante se refere aos 19 aglomerados de favelas que surgiram a norte, localizando-se muito próximos ao limite com a Serra da Cantareira, tanto no município de São Paulo como em Guarulhos.

\subsection{Caracterização regional}

Quando analisados o tamanho das ocupações, nota-se uma predominância por assentamentos pequenos ${ }^{6}$ de até 250 construções, com quase $70 \%$ do total. A segunda maior faixa de tamanho é a correspondente a 251 até 500 construções, com 17\%, e as faixas de tamanhos maiores ficaram com $5 \%$ ou menos do total de favelas mapeadas.

Tabela 2: Favelas recentes de acordo com seu tamanho em número de construções

\begin{tabular}{lcc}
\hline Tamanho & № & $\%$ \\
\hline $0-250$ & 81 & $69 \%$ \\
$251-500$ & 20 & $17 \%$ \\
$501-750$ & 6 & $5 \%$ \\
$751-1000$ & 5 & $4 \%$ \\
$>1000$ & 5 & $4 \%$ \\
Total & 117 & $100 \%$ \\
\hline
\end{tabular}

Fonte: Elaboração da autora a partir de dados do TETO BRASIL (2015, 2016 e 2017)

\footnotetext{
${ }^{6}$ Essa característica de predominância de favelas pequenas em São Paulo já foi observada a partir de dados da prefeitura municipal de São Paulo e dos aglomerados subnormais levantados pelo IBGE. Inclusive o fato de serem pequenas contribui para uma subestimação do número real de domicílios em favelas, tendo em vista a metodologia definida pelo IBGE de só considerar aglomerados subnormais nos casos em que há no mínimo 51 construções.
} 
Mapa 2: Favelas recentes de acordo com seu tamanho em número de construções

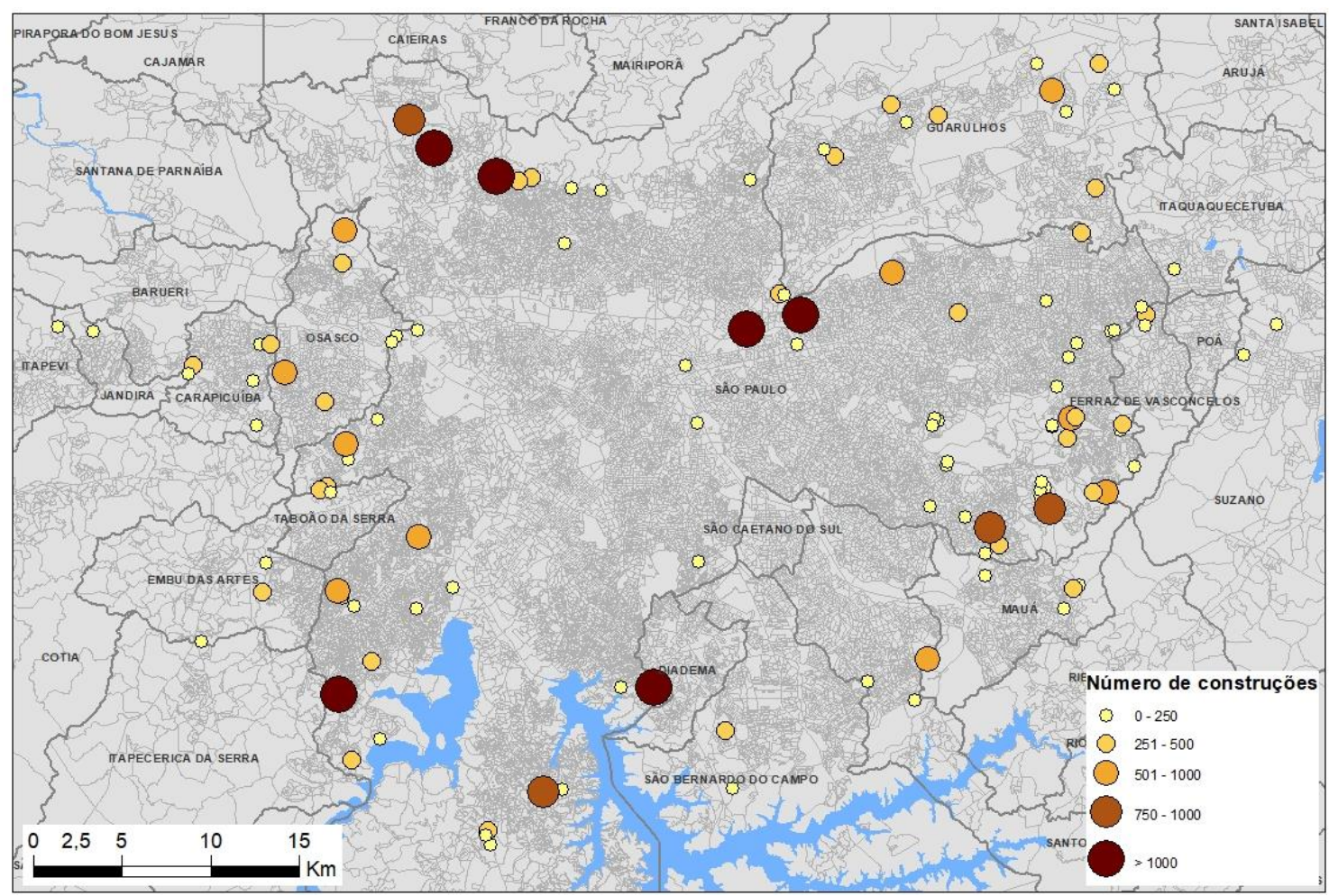

Fonte: Elaboração da autora

No que diz respeito à forma que se deu a ocupação, 25\% afirmaram terem ocupado o terreno de forma coletiva e organizada, enquanto $55 \%$, um total de 64 respostas, afirmam ter ocorrido de forma espontânea, em que os moradores foram ocupando de maneira progressiva. Para os 29 que responderam terem se organizado para ocupar, quando perguntado sobre os atuais responsáveis pela administração dos lotes, 11 responderam ser responsabilidade do próprio morador, 7 da associação comunitária, enquanto 11 não souberam informar ou não quiseram responder.

Tabela 3: Forma de ocupação das favelas recentes

\begin{tabular}{lll}
\hline Forma de ocupação & № & $\%$ \\
\hline Coletiva & 29 & 25 \\
Espontânea & 64 & 55 \\
Sem informação & 27 & 20 \\
Total & 117 & 100 \\
\hline
\end{tabular}

Fonte: Elaboração da autora a partir de dados do TETO BRASIL $(2015,2016$ e 2017) 
Tabela 4: Formação coletiva $x$ responsáveis pelos lotes

\begin{tabular}{lcc}
\hline Responsáveis & № & $\%$ \\
\hline Moradores & 11 & 38 \\
Associação & 7 & 24 \\
NS/NR & 11 & 38 \\
Total & 29 & 100 \\
\hline
\end{tabular}

Fonte: Elaboração da autora a partir de dados do TETO BRASIL $(2015,2016$ e 2017)

Também foi questionado sobre a dinâmica de compra e venda dos lotes na comunidade, 54\% afirmou haver compra e venda, enquanto que em $21 \%$ dos locais entrevistados afirmaram que essa prática não ocorre. Quando questionado a respeito dos responsáveis pelos lotes, seja por via de comércio ou de partilha comunitária entre famílias, $50 \%$ das respostas colocavam os próprios moradores dos lotes como responsáveis, enquanto $7 \%$ apontava a associação e 3\% admitiu que o controle de lotes era realizado pelo grupo de pessoas relacionado ao tráfico de drogas da região.

Tabela 5: Dinâmica de compra e venda de lotes nas favelas recentes

\begin{tabular}{lll}
\hline Compra e venda & № & $\%$ \\
\hline Sim & 63 & $54 \%$ \\
Não & 25 & $21 \%$ \\
Sem informação & 29 & $25 \%$ \\
Total & 117 & $100 \%$ \\
\hline
\end{tabular}

Fonte: Elaboração da autora a partir de dados do TETO BRASIL $(2015,2016$ e 2017)

Tabela 6: Responsáveis pelos lotes nas favelas recentes

\begin{tabular}{lcc}
\hline Responsáveis & № & $\%$ \\
\hline Moradores & 58 & $50 \%$ \\
Associação & 8 & $7 \%$ \\
Tráfico & 4 & $3 \%$ \\
Sem informação & 47 & $40 \%$ \\
Total & 117 & $100 \%$ \\
\hline
\end{tabular}

Fonte: Elaboração da autora a partir de dados do TETO BRASIL (2015, 2016 e 2017)

$\mathrm{O}$ alto percentual de ausência de informação sugere muitas recusas em responder essa pergunta. Os dados referentes à compra e venda de lotes são indicativos fortes de especulação imobiliária informal, grilagem e/ou outras dinâmicas ilícitas dentro das favelas. Por isso, os dados muitas vezes não são fornecidos em visitas pontuais. 
No que diz respeito aos materiais das moradias das 117 favelas mapeadas, 42\% delas apresentavam pisos de cimento como predominantes, seguidos de 19\% de cerâmica e 11\% de terra batida. Não houve informação para $28 \%$ das favelas.

Tabela 7: Material dos pisos das moradias nas favelas recentes

\begin{tabular}{lll}
\hline Material & № & \% \\
\hline Cimento & 49 & $42 \%$ \\
Cerâmica & 22 & $19 \%$ \\
Terra batida & 13 & $11 \%$ \\
Sem informação & 33 & $28 \%$ \\
Total & 117 & $100 \%$ \\
\hline
\end{tabular}

Fonte: Elaboração da autora a partir de dados do TETO BRASIL $(2015,2016$ e 2017)

Em relação às paredes, $43 \%$ das favelas eram constituídas majoritariamente por madeira, seguidas por $33 \%$ de alvenaria e apenas $1 \%$ de lona e de adobe. Do total, $22 \%$ da base não dispunha de informação para essa pergunta.

Tabela 8: Material predominante das paredes das moradias em favelas recentes

\begin{tabular}{lcc}
\hline Material & № & $\%$ \\
\hline Madeira & 50 & $43 \%$ \\
Alvenaria & 39 & $33 \%$ \\
Adobe & 1 & $1 \%$ \\
Lona & 1 & $1 \%$ \\
Sem informação & 26 & $22 \%$ \\
Total & 117 & $100 \%$
\end{tabular}

Fonte: Elaboração da autora a partir de dados do TETO BRASIL (2015, 2016 e 2017)

Quanto ao telhado, 72\% das 117 favelas apresentavam telhados de fibrocimento, conferindo apenas $2 \%$ à laje e zinco como forma de cobertura das moradias. 24\% não apresentou resposta válida.

Tabela 9: Material predominante dos telhados das moradias em favelas recentes

\begin{tabular}{lcc}
\hline Material & № & $\%$ \\
\hline Fibrocimento & 84 & $72 \%$ \\
Laje & 2 & $2 \%$ \\
Zinco & 2 & $2 \%$ \\
Sem informação & 29 & $24 \%$ \\
Total & 117 & $100 \%$ \\
\hline
\end{tabular}

Fonte: Elaboração da autora a partir de dados do TETO BRASIL $(2015,2016$ e 2017) 
Ao considerar apenas as respostas válidas no que diz respeito à materialidade das moradias, verificou-se que a favela recente é predominantemente construída em madeira, com 55\% das respostas, mas que há um número considerável de alvenaria, com $43 \%$. Os pisos das moradias são, majoritariamente, feitos de cimento, com $58 \%$ do total, $26 \%$ são de cerâmica e 15\% apresentam moradias com chão de terra batida. Quanto aos telhados, quase a totalidade, ou seja, $95 \%$ é construída com fibrocimento.

Gráfico 4: Materialidade das moradias em favelas recentes

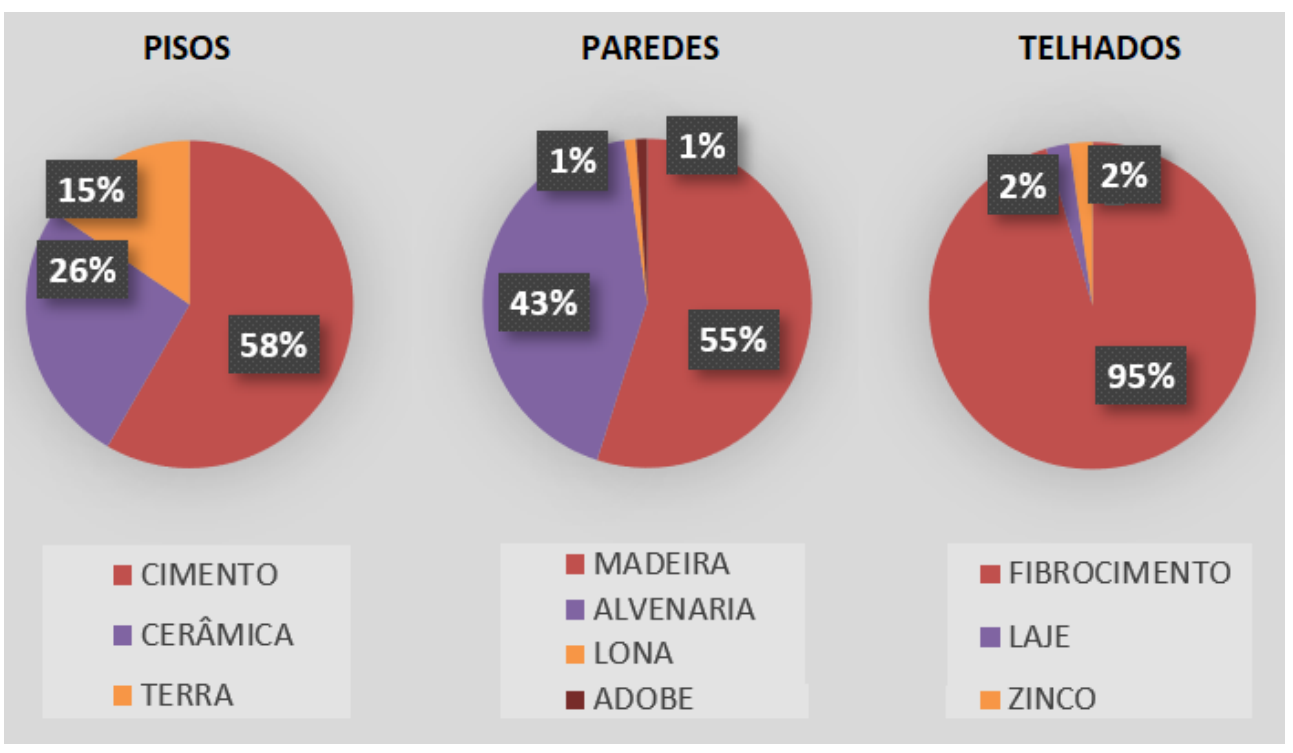

Fonte: Elaboração da autora a partir de dados do TETO BRASIL $(2015,2016$ e 2017)

Figura 3: Típica favela recente em Guarulhos

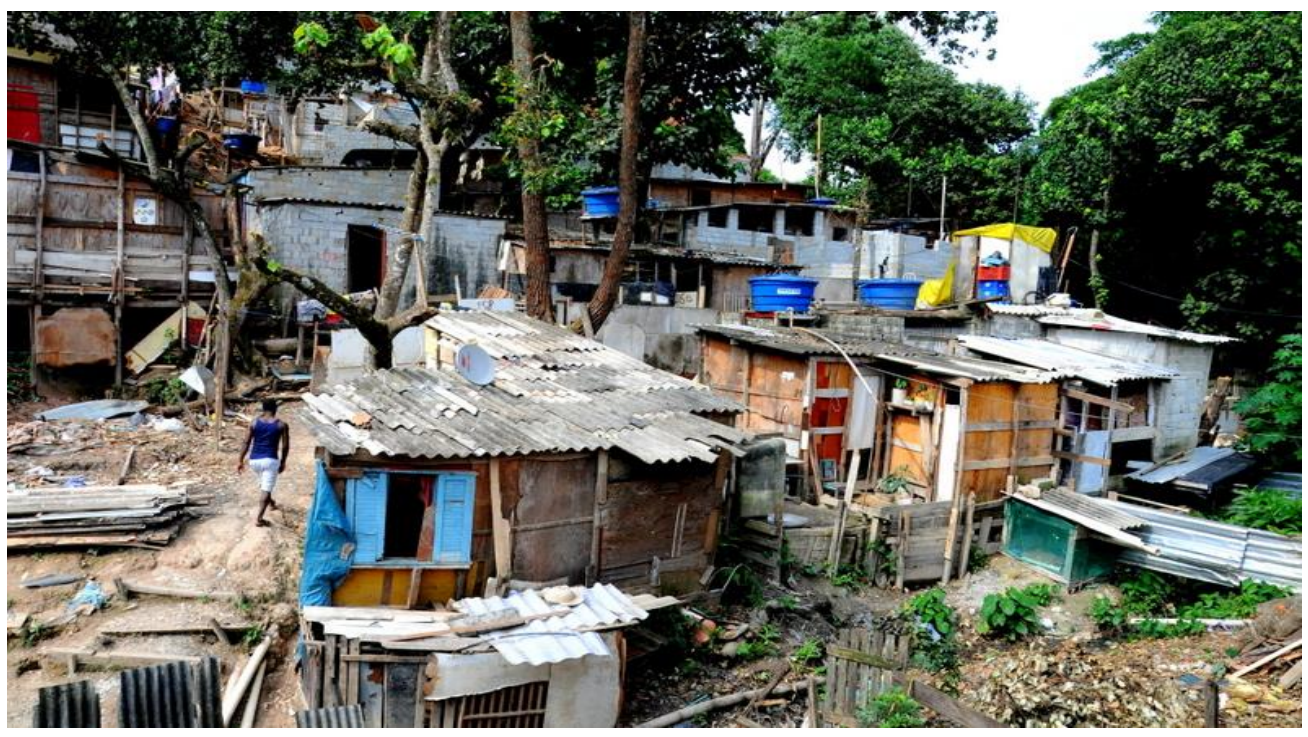

Fonte: TETO BRASIL (2017) 


\subsection{Distribuição por zoneamento}

A fim de compreender as características territoriais predominantes das favelas recentes, foi realizado um trabalho de sobreposição dos mapas de zoneamento dos planos diretores de cada município.

Em Embu das Artes, foram encontradas duas favelas recentes. Quando sobrepostas com o zoneamento municipal, uma que contabilizava 300 construções se localizava na Zona Especial de Interesse Ambiental, área passível de ocupação desde que com baixa densidade. A outra, com um total de 250 construções, estava dentro de uma Zona Especial de Interesse Social, área em que predominam terrenos vazios situados em regiões dotadas de infraestrutura e que prevê o uso para a construção de habitações de interesse social. (EMBU DAS ARTES, 1978)

No município de Itapecerica da Serra, foi encontrada uma favela com 80 construções localizada na Zona de Interesse Coletivo que, conforme lei de zoneamento de 2001, são áreas em que predominam terrenos vazios a serem utilizados para usos de interesse coletivo, cuja definição se dará em segunda instância pela administração local, podendo inclusive serem transformadas em ZEIS, por exemplo. (ITAPECERICA DA SERRA, 2001)

Em Itaquaquecetuba, a única favela encontrada apresentava 150 construções e estava localizada na Zona de Uso em Consolidação, que, segundo lei de 2001, se refere a zonas urbanas ainda não consolidadas que podem ser indicadas para usos diversos, inclusive para implementação de empreendimentos habitacionais de interesse social. (ITAQUAQUECETUBA, 2009)

Duas favelas foram mapeadas em Jandira, somando um total de 150 construções. Ambas estavam localizadas em Zona Empresarial, que prevê uso predominantemente industrial, segundo lei de 2006 que dispóe sobre o zoneamento municipal. (JANDIRA, 2006)

No município de Mauá, duas das quatro favelas mapeadas totalizavam 650 construções e se localizavam na Zona de Desenvolvimento Econômico, que dá prioridade para usos industriais, de comércio e serviço, segundo lei municipal 
de 2007. As outras duas, com um total de 250 construções, se encontravam em Zona de Uso Diversificado, adequado para uso residencial, mas que prioriza o estabelecimento comercial e industrial, de acordo com o Plano Diretor. (MAUÁ, 2007)

O mapeamento no município de Osasco resultou em quatro favelas: duas inseridas em Zona Especial de Interesse Social, somando 850 construções; uma em uma zona de uso predominantemente industrial, com 600 construções; e uma em uma zona de uso prioritariamente residencial de média e alta densidade, com um total de 200 construções. (OSASCO, 2006)

$\mathrm{Na}$ capital paulistana, das 75 favelas mapeadas, 47 estavam inseridas em Zonas Especiais de Interesse Social, com mais de 22 mil construções; 13 se localizavam em zonas de proteção ambiental, com quase 2,5 mil construções; cinco em zonas de uso misto, com mais de 1,5 mil construções, destinadas a uso residenciais e não-residenciais; quatro em zonas de uso predominantemente industriais, totalizando 775 construções; e quatro em zonas de centralidades, com 490 construções, reservadas para atividades típicas de áreas centrais ou centros de bairro. A área de uma das favelas, com 2 mil construções não constava zoneamento, pois sua definição havia sido vetada no momento de aprovação da lei em 2014. (SÃO PAULO, 2014)

No município de São Bernardo, foram localizadas duas favelas que, somadas, totalizavam 520 construções, ambas inseridas em Zona Especial de Interesse Social. (SÃO BERNARDO DO CAMPO, 2012)

Em Suzano, foram mapeadas duas favelas, uma delas com 90 construções, localizada em Zona Especial de Interesse Social, e a outra com 120 construções, inserida na Área de Preservação Ambiental da várzea do Rio Tietê. (PREFEITURA MUNICIPAL DE SUZANO, 2015)

Em Taboão da Serra, foi localizada uma favela com 140 construções, a qual se inseria em Zona de Preservação Ambiental, que restringe consideravelmente o uso do solo, tendo como prioridade a preservação da 
vegetação nessas áreas, conforme Plano Diretor de 2006. (PREFEITURA MUNICIPAL DE TABOÃO DA SERRA, 2006)

Não foram encontrados para consulta os mapas de zoneamento de Carapicuíba e Ferraz de Vasconcelos. Apesar disso, a fim de compreender minimamente a inserção das favelas nesses municípios, fez-se uma análise com base no mapa de Uso e Ocupação do Solo elaborado pela Empresa Paulista de Planejamento Metropolitano S.A (Emplasa) por iniciativa do Governo do Estado em São Paulo, em 2006.

Em Carapicuíba, foram mapeadas seis favelas. No que diz respeito à aptidão física ao assentamento urbano, quatro estavam localizadas em "Áreas com restrições localizadas", somando 740 construções. Duas estavam localizadas em "Áreas com severas restrições", com um total de 500 construções. Já em Ferraz de Vasconcelos, foram encontradas três favelas, sendo duas localizadas em "Áreas com restrições localizadas," com 640 construções, e uma em "Áreas com severas restrições", somando 300 construções.

Guarulhos e Santo André são municípios que dispõem de planos diretores e leis de zoneamento. No entanto, nesse momento passam por um processo de revisão de suas legislações e, por isso, não estavam disponíveis os mapas de zoneamentos anteriores. A fim de ter uma compreensão mínima de suas territorialidades, a mesma análise foi realizada com base nos mapas da Emplasa.

Em Guarulhos, foram mapeadas 11 favelas, três localizadas em "áreas favoráveis", com 1320 construções, cinco localizadas em "Áreas com restrições localizadas", somando 1460 construções, e três localizadas em "Áreas com severas restrições", com um total de 570 construções. Em Santo André, duas em "Áreas passíveis de ocupação com severas restrições", totalizando 230 construções, e uma em "Áreas com severas restrições”, com 50 construções.

A síntese da leitura dos zoneamentos municipais pode ser observada na tabela a seguir: 
Tabela 10: Inserção das favelas recentes nos zoneamentos municipais

\begin{tabular}{|c|c|c|c|c|c|c|c|c|c|c|c|c|}
\hline \multirow{2}{*}{$\begin{array}{l}\frac{0}{a} \\
\frac{0}{0} \\
\frac{2}{5} \\
\frac{5}{2}\end{array}$} & \multicolumn{2}{|c|}{$\frac{\mathscr{D}}{\stackrel{W}{N}}$} & \multicolumn{2}{|c|}{ 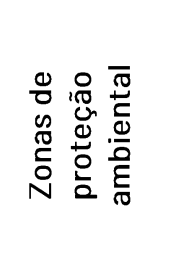 } & \multicolumn{2}{|c|}{ 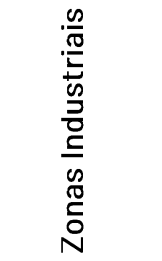 } & \multicolumn{2}{|c|}{ 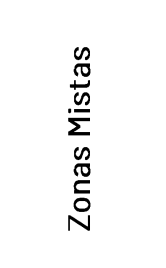 } & \multicolumn{2}{|c|}{ 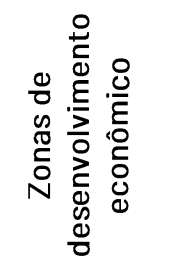 } & \multicolumn{2}{|c|}{ 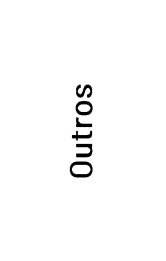 } \\
\hline & 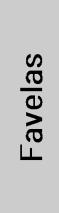 & 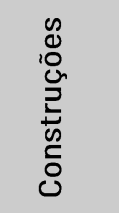 & 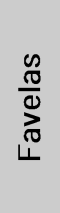 & 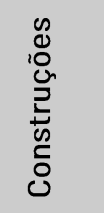 & 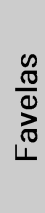 & 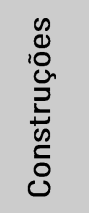 & 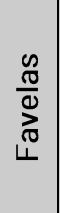 & 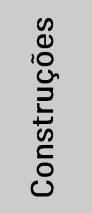 & 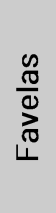 & 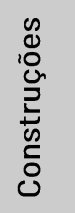 & 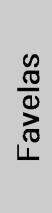 & 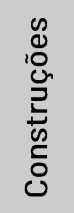 \\
\hline Carapicuíba & - & - & - & - & - & - & - & - & - & - & - & - \\
\hline Embu das Artes & 1 & 200 & 1 & 250 & 0 & 0 & 0 & 0 & 0 & 0 & 0 & 0 \\
\hline $\begin{array}{c}\text { Ferraz de } \\
\text { Vasconcelos }\end{array}$ & - & - & - & - & - & - & - & - & - & - & - & - \\
\hline Guarulhos & - & - & - & - & - & - & - & - & - & - & - & - \\
\hline $\begin{array}{l}\text { Itapecerica da } \\
\text { Serra }\end{array}$ & 0 & 0 & 0 & 0 & 0 & 0 & 0 & 0 & 0 & 0 & 1 & 80 \\
\hline Itaquaquecetuba & 0 & 0 & 0 & 0 & 0 & 0 & 0 & 0 & 0 & 0 & 1 & 150 \\
\hline Jandira & 0 & 0 & 0 & 0 & 2 & 150 & 0 & 0 & 0 & 0 & 0 & 0 \\
\hline Mauá & 0 & 0 & 0 & 0 & 0 & 0 & 2 & 250 & 2 & 650 & 0 & 0 \\
\hline Osasco & 2 & 850 & 0 & 0 & 1 & 600 & 0 & 0 & 0 & 0 & 1 & 200 \\
\hline Santo André & - & - & - & - & - & - & - & - & - & - & - & - \\
\hline $\begin{array}{c}\text { São Bernardo do } \\
\text { Campo }\end{array}$ & 2 & 520 & 0 & 0 & 0 & 0 & 0 & 0 & 0 & 0 & 0 & 0 \\
\hline São Paulo & 47 & 22460 & 13 & 2490 & 4 & 775 & 6 & 1570 & 0 & 0 & 5 & 2490 \\
\hline Suzano & 1 & 90 & 1 & 120 & 0 & 0 & 0 & 0 & 0 & 0 & 0 & 0 \\
\hline Taboão Da Serra & 0 & 0 & 1 & 140 & 0 & 0 & 0 & 0 & 0 & 0 & 0 & 0 \\
\hline Total & 53 & 24120 & 16 & 3000 & 5 & 1375 & 8 & 1820 & 4 & 650 & 8 & 2920 \\
\hline
\end{tabular}

Fonte: Elaborado pela autora a partir das leis de zoneamento dos municípios listados

Os resultados que surgem a partir das sobreposições com os zoneamentos municipais revelam que mais da metade das 117 favelas analisadas, com um total de 53, estavam inseridas dentro de Zonas Especiais de Interesse Social. Quando olhamos apenas para o número absoluto de construções - quase 
39 mil -, essa porcentagem salta para $71 \%$, enquanto apenas $9 \%$ estavam em zonas de proteção ambiental.

\subsection{Aspectos cronológicos}

Quando analisada ano a ano, a expansão territorial se mostrou baixa em 2011 e 2012, com pouco mais de 1000 construções no primeiro ano e quase 700 no segundo. No entanto, houve um crescimento repentino de 7 mil em 2013, até atingir o maior pico em 2014, com mais de 12 mil novas moradias. Em 2015, manteve o alto crescimento, com 7 mil. Em 2016, chegou a quase 6 mil, decrescendo em 2017, com aproximadamente 4 mil. Ainda que tenham havido remoções ao longo dos anos, em nenhum ano o número de construções decresceu, apenas apresentou variação na taxa de crescimento.

Tabela 11: Crescimento de construções em favelas recentes ao longo da década

\begin{tabular}{c|c|c|c|c|c|c|c} 
& 2011 & 2012 & 2013 & 2014 & 2015 & 2016 & 2017 \\
\hline Total de construções & 1035 & 1725 & 9050 & 21620 & 28920 & 34670 & 38825 \\
\hline Novas construções por ano & 1035 & 690 & 7325 & 12570 & 7300 & 5750 & 4155 \\
\hline
\end{tabular}

Fonte: Elaboração da autora com base em Google Earth(2017)

Gráfico 5: Crescimento do número de construções em favelas recentes

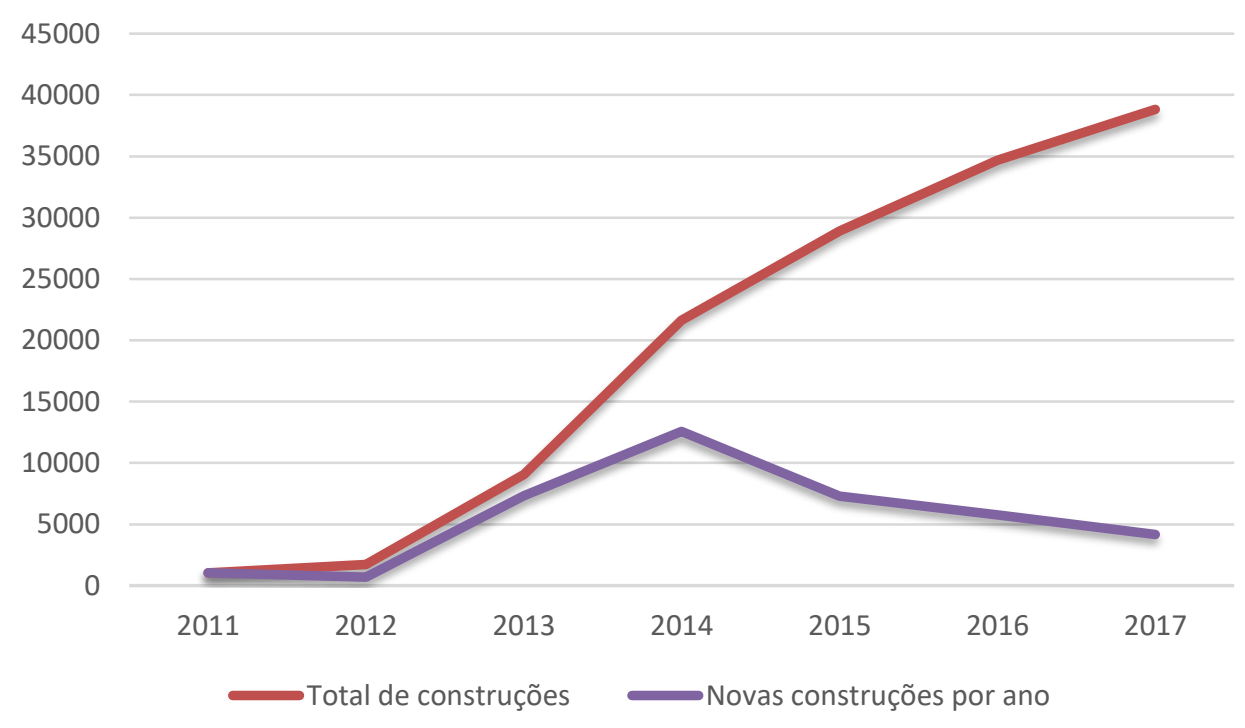

Fonte: Elaboração da autora com base em GOOGLE EARTH (2017) 
Ao observar o crescimento exponencial concentrado principalmente nos anos de 2013, 2014 e 2015, buscou-se encontrar explicações para esse fenômeno. A primeira suposição feita tinha relação direta com a economia do país, portanto recorreu-se a referências de pesquisas que pudessem comprovar essa hipótese. Um estudo elaborado por Menezes e Januzzi (2018) a partir dos resultados da Pesquisa Nacional por Amostra de Domicílio (PNAD), concluiu que houve um crescimento da extrema pobreza principalmente a partir da virada do ano de 2014 para 2015.

Gráfico 6: Pessoas em pobreza e pobreza extrema no Brasil (1992-2016)

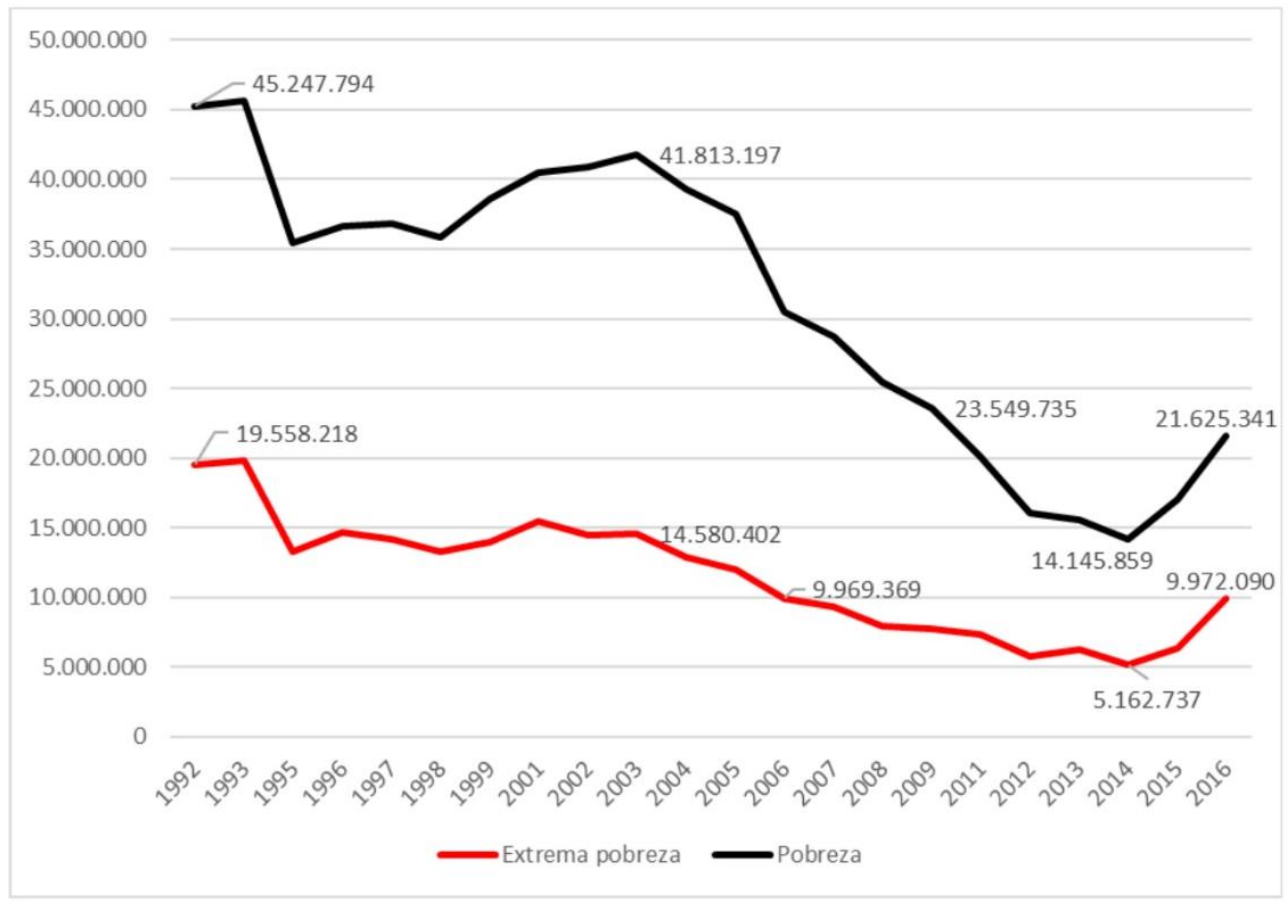

Fonte: MENEZES e JANNUZZI (2018)

Os autores observaram que, nas últimas duas décadas, o país viveu dois momentos de diminuição da pobreza: o primeiro em 1995, muito provavelmente devido à estabilização da moeda, e o segundo entre os anos de 2003 e 2013 , durante os dois mandatos de Luiz Inácio Lula da Silva e o primeiro mandato de Dilma Rousseff, em que houve uma "virtuosa combinação de uma política de desenvolvimento com inclusão por meio de programas e ações especificamente voltados para grupos sociais mais vulneráveis." 
No entanto, há uma interrupção dessa trajetória e, por meio dos dados divulgados pela PNAD,

[...] assiste-se a um agudo empobrecimento de parte da população, retrocedendo a patamares que tinham sido superados. É muito preocupante que, no que diz respeito à extrema pobreza, o Brasil voltou, em apenas dois anos, ao número de pessoas registradas dez anos antes, em 2006. Entre 2014 e 2016 o aumento desse contingente foi de 93\%, passando de 5,1 milhões para 10 milhões de pessoas. Em relação aos pobres, o patamar de 2016 - 21 milhões - é o equivalente ao de oito anos antes, em 2008, e cerca de $53 \%$ acima do menor nível alcançado no país, de 14 milhões, em 2014. (MENEZES e JANUZZI, 2018)

Pochmann (2016) também apontou queda na desigualdade na renda entre os anos de 2003 e 2012. Segundo o autor, apesar da crise global iniciada em 2008, as medidas econômicas adotadas pelo Brasil mantiveram a taxa de desemprego decrescente até o fim de 2014.

O economista observa, no entanto, o reaparecimento da recessão a partir de 2015, e destaca os principais efeitos no mercado de trabalho:

[...] o ano de 2015 pode ser compreendido com um ponto de inflexão no comportamento do mercado de trabalho desde o início dos anos 2000. Após vários anos de trajetória de queda, a taxa de desemprego do Brasil metropolitano voltou a crescer significativamente, chegando a ser $41,5 \%$ superior no mês de julho em comparação a janeiro de 2015. No mesmo período de tempo, por exemplo, a taxa de desemprego foi $2,1 \%$ maior em 2014, 3,7\% superior em 2013 e 1,8\% inferior em 2012. (POCHMANN, 2016)

Outro ponto muito válido comentado por Pochmann (2016) foram as atividades mais afetadas e que tiveram maior crescimento na taxa de desemprego durante o ano de 2015: o trabalho doméstico (72,2\%), a construção civil $(54,3 \%)$ e a indústria (45,2\%).

Esses dados de conjuntura nacional apontam inegavelmente para 0 empobrecimento das classes mais baixas a partir da segunda metade da década. Entretanto, não justificam o crescimento repentino das favelas recentes em 2013 e o pico sofrido em 2014. Com o intuito de compreender melhor a natureza dessas ocupações e encontrar outras hipóteses para justificar esses números, outros dados foram considerados e analisados quantitativamente, ano a ano. 
Para elaborar os três gráficos seguintes, foram considerados os dados das 94 favelas recentes que estavam inseridas em municípios que dispunham do mapa de zoneamento no momento em que essa pesquisa estava sendo desenvolvida. O primeiro gráfico apresenta o número de construções ano a ano, considerando as 94 favelas da conurbação urbana. O segundo gráfico apresenta os dados das favelas de São Paulo, que somam um total de 75, enquanto o último, com 19 favelas recentes, apresenta os dados das favelas localizadas nos municípios de Embu das Artes (2), Itapecerica da Serra (1), Itaquaquecetuba (1), Jandira (2), Mauá (4), Osasco (4), São Bernardo do Campo (2), Suzano (2) e Taboão da Serra (1).

Gráfico 7: Número de construções por ano na metrópole, no município de São Paulo e em outros municípios

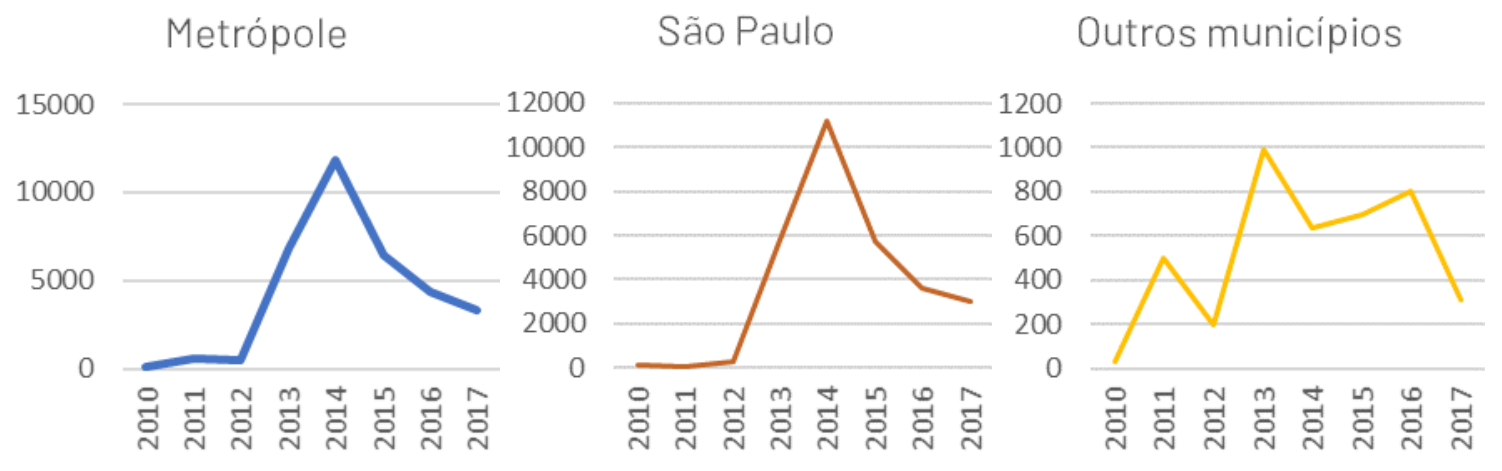

Fonte: Elaborado pela autora

A semelhança entre as linhas de crescimento do primeiro e do segundo gráfico, somada à diferença entre as linhas do segundo e do terceiro gráfico, denotam que o pico atingido em 2014 se concentrou no município de São Paulo.

Os gráficos seguintes repetem a lógica das localidades apontada nos gráficos anteriores. Na primeira linha de gráficos, considerou-se apenas os dados das favelas recentes que se localizavam em ZEIS. Foram analisadas 53 favelas no total, das quais 47 localizadas em São Paulo, enquanto apenas seis se concentravam nos demais municípios. Os gráficos da segunda linha foram elaborados com dados de favelas que se localizavam em outros zoneamentos que não o de ZEIS. No total, foram consideradas 41 favelas, sendo 28 no município de São Paulo e 13 em outros municípios adjacentes da conurbação urbana. 
Gráfico 8: Número de construções em ZEIS por ano na metrópole, no município de São Paulo e em outros municipios

\section{Metrópole-ZEIS São Paulo-ZEIS Sutros municípios-ZEIS}

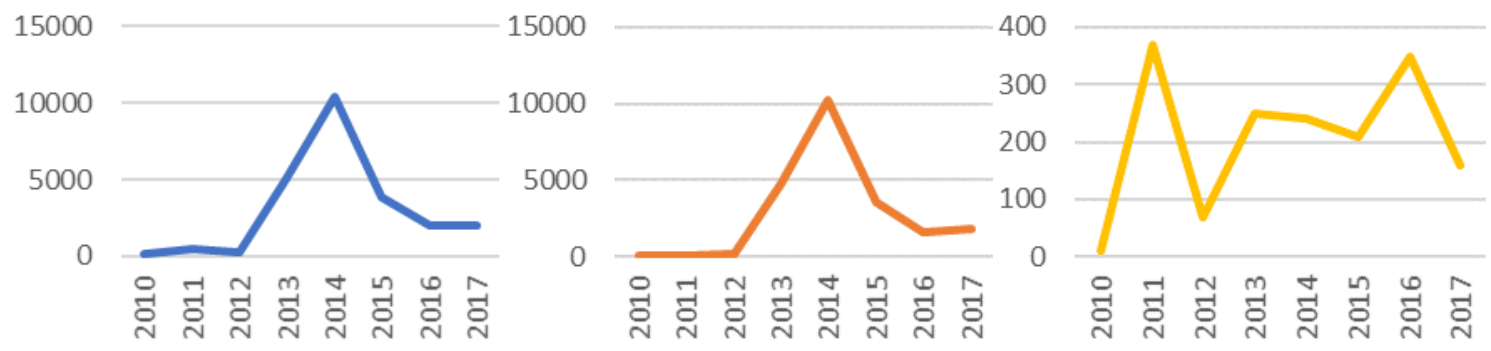

Fonte: Elaborado pela autora

Gráfico 9: Número de construções exceto em ZEIS por ano na metrópole, no município de São Paulo e em outros municipios

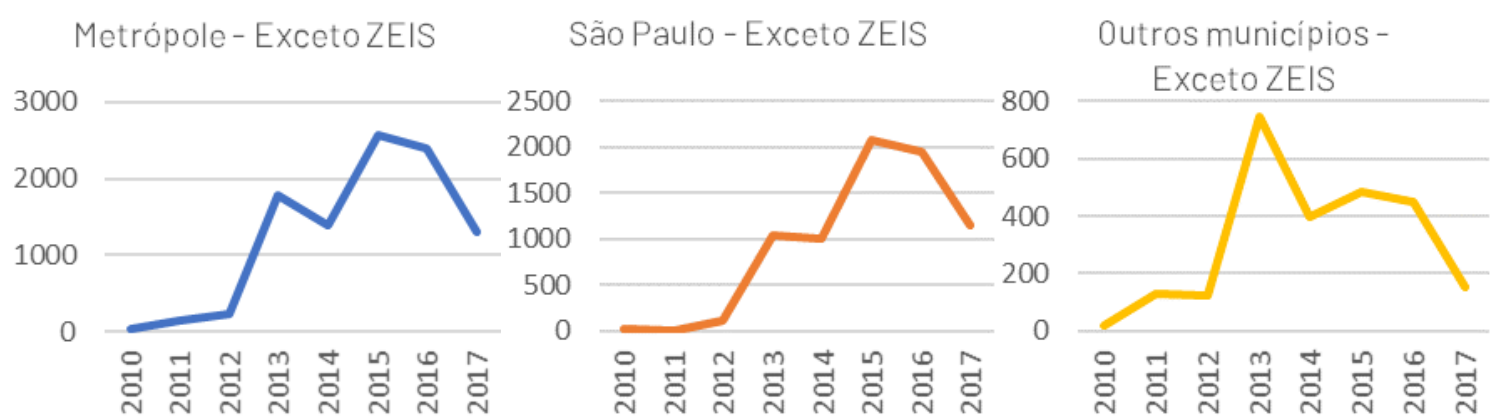

Fonte: Elaborado pela autora

Como já explicitado anteriormente, o número de novas construções localizadas em ZEIS no ano de 2017 atingiam 71\% do total contabilizado nesse estudo. A partir dos gráficos apresentados, fica perceptível que a maior parte também se concentrava no município de São Paulo e que o pico de novas construções se deu no ano de 2014, com aproximadamente 10 mil.

Por outro lado, ainda em São Paulo, em outras zonas que não ZEIS, o aumento de construções se mostrou maior nos anos de 2015 e 2016, com números próximos a 2 mil, enquanto para outros municípios o pico foi em 2013 com, aproximadamente, 700 novas construções. Em outros municípios, o número de novas construções foi menor em ZEIS do que nos demais zoneamentos, lógica contrária ao que ocorreu em São Paulo. 
Ainda na busca de compreender a natureza dessas ocupações novas, fezse uma separação entre as favelas que haviam se formado por meio de iniciativas coletivas e as que haviam se formado de maneira espontânea. A primeira linha dos gráficos a seguir contempla dados das 25 favelas cujos moradores se organizaram coletivamente para a ocupação, sendo 20 no município de São Paulo e cinco em outros municípios. Já na segunda linha foram contemplados dados de favelas que se formaram espontaneamente, sem qualquer iniciativa coletiva, com um total de 64 favelas, 40 em São Paulo, 24 nos demais municípios.

Gráfico 10: Número de construções em favelas de iniciativa coletiva por ano na metrópole, no município de São Paulo e em outros municípios

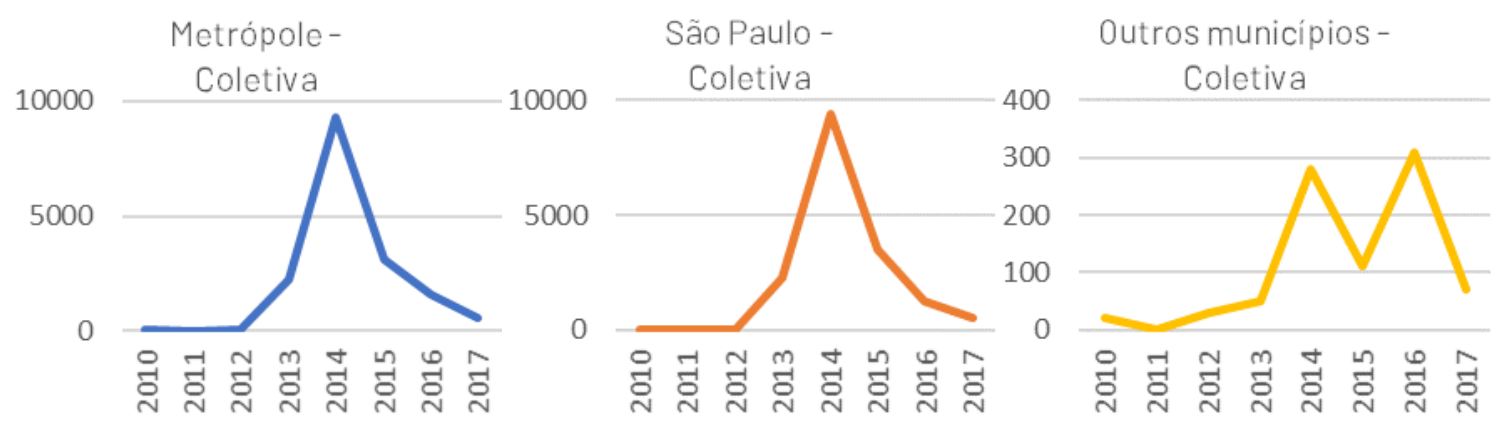

Fonte: Elaborado pela autora

Gráfico 11: Número de construções em favelas espontâneas por ano na metrópole, no município de São Paulo e em outros municípios

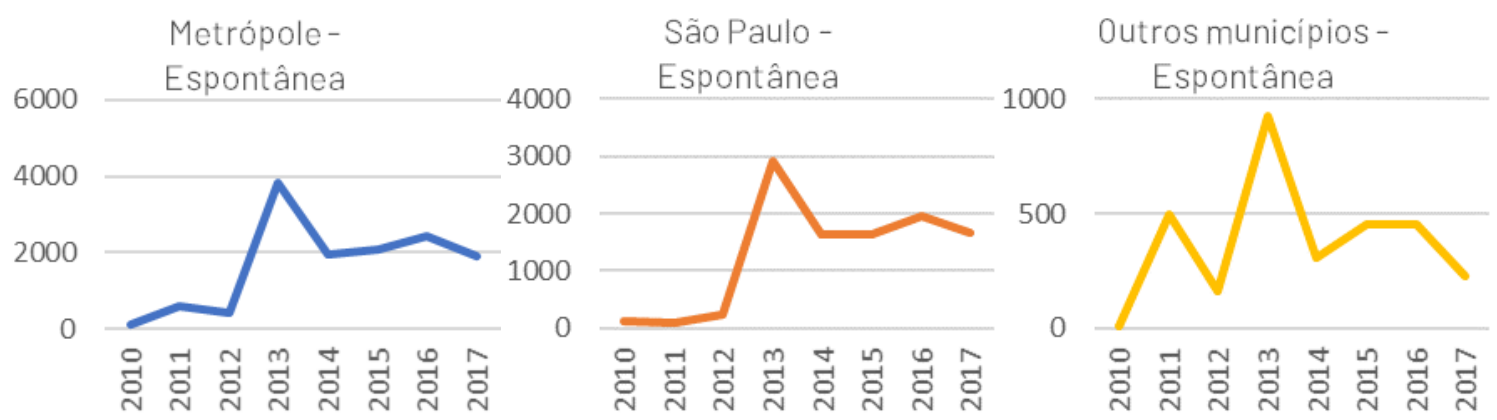

Fonte: Elaborado pela autora

Uma primeira observação importante a se fazer levando em conta os gráficos apresentados é que, embora o número de favelas formadas espontaneamente seja maior tanto em São Paulo, quanto em outros municípios, quando olhamos apenas para o número de construções, ele se mostra maior em 
favelas organizadas coletivamente. A média do número de construções nas favelas de surgimento espontâneo é de aproximadamente 240 por assentamento, enquanto naquelas de ocupação coletiva o número sobe para cerca de 680 .

Outro ponto a ser observado é que, para o município de São Paulo, as curvas dos gráficos de ocupações coletivas e de favelas localizadas em ZEIS é semelhante, considerando-se o grande pico em 2014. O dado sugere que as grandes ocupações surgiram de uma só vez e que propositalmente se fixaram em zoneamentos nos quais as remoções seriam menos prováveis. Por outro lado, há também uma concentração de novas construções em favelas de surgimento espontâneo no ano de 2013.

Foram elaborados gráficos considerando apenas favelas em áreas de proteção ambiental, já que esse tipo de zoneamento foi o que apareceu em segundo lugar com maior número de construções. No total, foram contabilizadas 16 favelas, em que 13 se localizavam em São Paulo e três nos outros municípios.

Gráfico 12: Número de construções em áreas de proteção ambiental por ano na metrópole, no município de São Paulo e em outros municípios

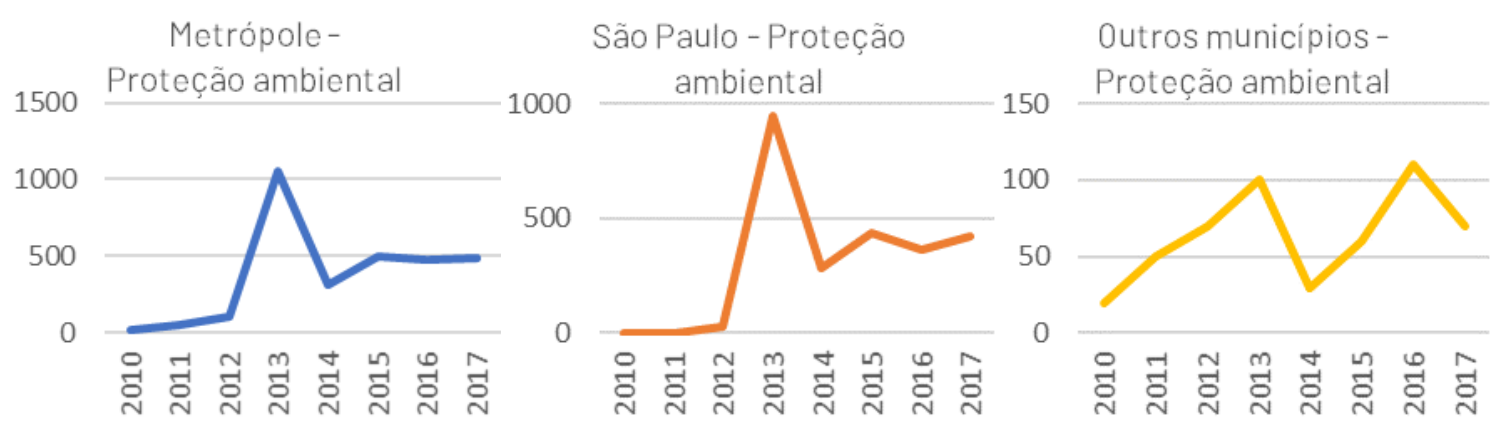

Fonte: Elaborado pela autora

Como é possível observar, para o município de São Paulo, o pico de novas favelas em áreas de Proteção Ambiental no ano de 2013 é semelhante ao pico das favelas surgidas espontaneamente mostradas nos gráficos anteriores. Isso é um forte indício de que as duas características estão conectadas, assim como há relação entre as favelas de formação coletiva e as favelas em áreas de ZEIS. 


\subsection{Considerações sobre os dados}

De maneira geral, percebe-se que os gráficos e dados quantitativos, quando olhados na escala metropolitana, refletem quase que exclusivamente as dinâmicas do município de São Paulo. A amostra dos demais municípios da Região Metropolitana é insuficiente e não aponta tendências claras. Após uma leitura conjunta dos dados, a partir das visões dos zoneamentos municipais e da cronologia, fica nítido que grande parte das ocupações ocorrem em picos de acordo com as dinâmicas das políticas municipais. É difícil, assim, tirar conclusões olhando para um conjunto de municipalidades. Para uma análise adequada dos demais municípios, seria necessária uma amostra maior e um estudo focado individual por município.

O que se pode afirmar com certeza é que o local de surgimento dessas novas favelas não é aleatório. Em 2013, elas surgem em espaços adjacentes à malha urbana, geralmente em vazios urbanos, fazendo proveito da infraestrutura já existente. A maior parte se localiza no limite da conurbação da metrópole de São Paulo, todas dentro dos perímetros urbanos de seus municípios. $\mathrm{O}$ alto número de novas construções, concentrado principalmente no ano de 2013 e em áreas de proteção ambiental, tem relação direta com essa tendência, visto que são as poucas áreas de grande porte remanescentes nas franjas da cidade e que não competem com o mercado formal.

O exacerbado crescimento de favelas recentes a partir de 2013 não pode ser justificado unicamente como consequência da crise econômica, já que os números da PNAD revelaram aumento da pobreza a partir do ano de 2015, mesmo ano em que as taxas de desemprego começaram a crescer.

Tendo em vista que os picos de novas construções ocorreram nos anos de 2013 e 2014 e foram concentrados principalmente no município de São Paulo, a hipótese que se levantou está diretamente relacionada ao processo de revisão do Plano Diretor que se deu entre os anos de 2013 e 2014.

É destaque dessa pesquisa a confirmação de que há uma concentração de novas construções de favelas recentes ocorridas no município de São Paulo, no 
período de 2014, ocupando áreas de ZEIS e surgidas a partir de iniciativas coletivas. E se, por um lado, favelas localizadas nesse tipo de zoneamento têm uma chance maior de permanência no local, já que as ZEIS foram criadas com o objetivo de promover habitações de interesse social, por outro aspecto, essas novas favelas apresentam características de habitat e habitabilidade muito precárias. Ou seja, nesse caso, o instrumento de demarcação dessas áreas pode estar garantindo a posse e a permanência de famílias, mas não necessariamente o direito à moradia adequada.

Outro ponto significativo a ser considerado é o de que, ainda que os gráficos demonstrem um crescimento exacerbado e fora do esperado para os anos de 2013 e 2014, principalmente, não se pode ignorar o crescimento de favelas que surgem posteriormente e se enquadram já num contexto de crise econômica, aumento do desemprego e alta dos aluguéis. 
66 • favelas na metrópole de são paulo 


\section{OS ESTUDOS DE CASO}

Após a leitura regional das favelas recentes, buscou-se fazer uma aproximação do objeto de estudo por meio da base de dados comunitária, abordando características a partir de uma escala mais aproximada.

Tendo como referência quatro estudos de caso, pretende-se responder a algumas perguntas como: há diferenças entre uma favela recente formada por iniciativa coletiva e uma favela formada espontaneamente? A localização tem impacto no modo como o assentamento se forma? O perfil da população pode se diferenciar de uma favela para outra?

Para responder a essas questões, foram escolhidas quatro favelas localizadas em pontos extremos da metrópole - norte, sul, leste e oeste -, de tamanhos variados, sendo duas com surgimento espontâneo e duas formadas a partir de iniciativas promovidas por movimentos sociais.

Dentre as favelas que possuíam esse tipo de levantamento de dados realizado pelo TETO, a escolha foi feita obedecendo ao recorte temporal estudado, buscando localizações variadas dentro da metrópole e formas de ocupação diferentes.

A primeira favela apresentada, conhecida como Fazendinha, está localizada em Osasco; outras três estão no município de São Paulo: Luiz Rubino, na Zona Leste, Olga Benário, na Zona Sul, e Pernilongo, na Zona Norte. As duas últimas citadas foram ocupações surgidas a partir de iniciativas coletivas, enquanto as outras duas surgiram espontaneamente.

Para cada um dos estudos de caso foi elaborada uma breve contextualização e, em seguida, apresentadas as características físicas, de infraestrutura, habitabilidade, para, por último, abordar aspectos socioeconômicos da população residente. 
Figura 4: Localização das favelas definidas como estudos de caso na RMSP

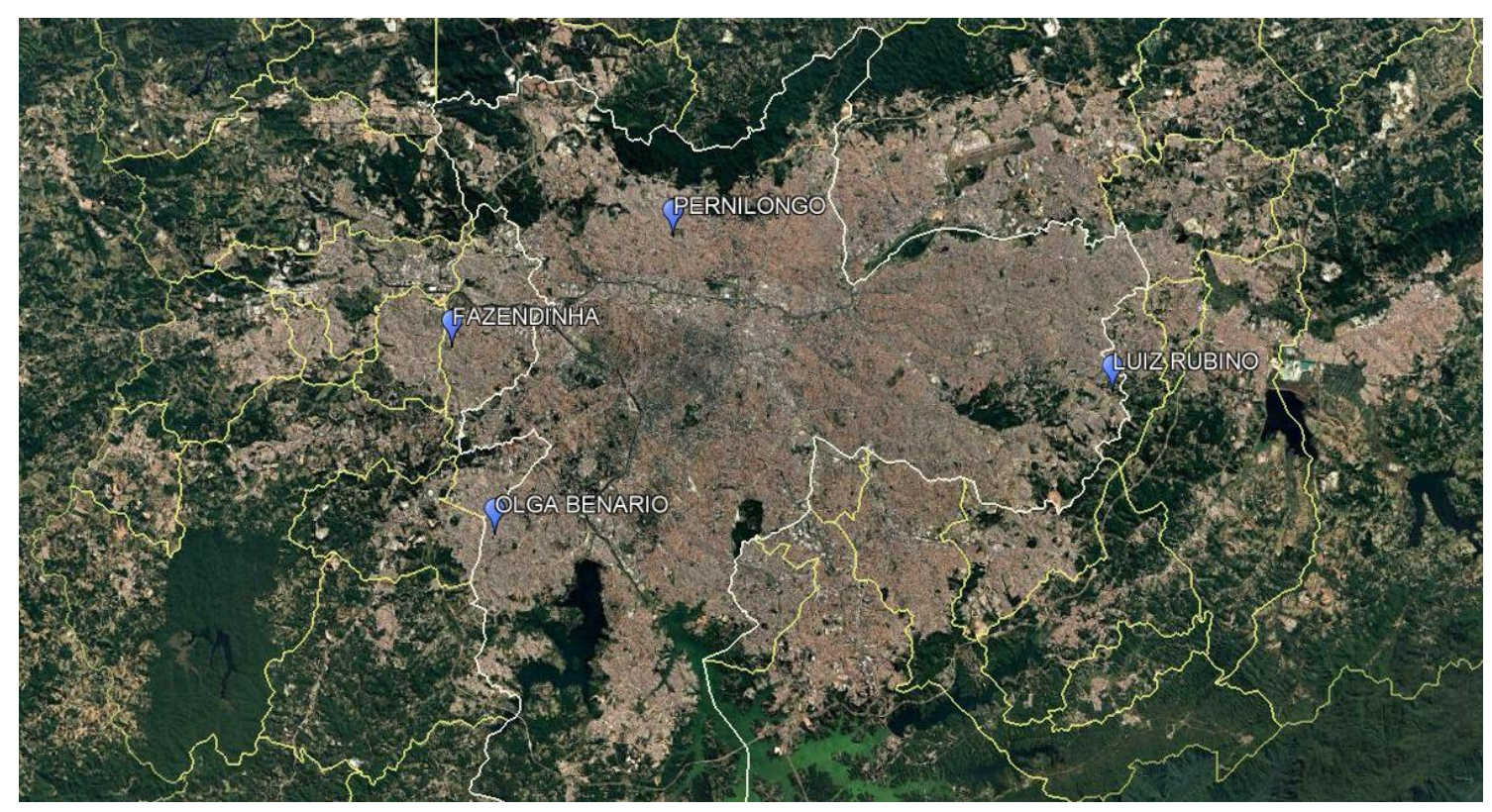

Fonte: Google Earth, editado pela autora

\subsection{Fazendinha, Osasco}

Fazendinha é uma favela localizada em Osasco, no Distrito Sudoeste, bairro São Pedro, região consolidada, que dispõe de infraestrutura e fácil acesso a serviços públicos. O terreno está inserido uma área de ZEIS 1, que prevê a promoção de Habitação de Interesse Social (HIS), segundo Plano Diretor municipal.

Imagens de satélite de anos anteriores a 2010 mostram que, em 2002, o terreno fazia parte de uma grande gleba desocupada. Em 2005, com a construção de um conjunto habitacional próximo, surgiu no terreno da Fazendinha um pequeno aglomerado de casas. A expansão de construções se iniciou, então, em 2013, e permaneceu crescendo até 2017.

Antes da ocupação completa da área de 3,4 hectares, uma parte do terreno continha árvores de porte alto, em quantidade que se reduziu gradativamente conforme as moradias foram sendo construídas. 
Figura 5: Fazendinha e o entorno imediato (raio de 500 metros)

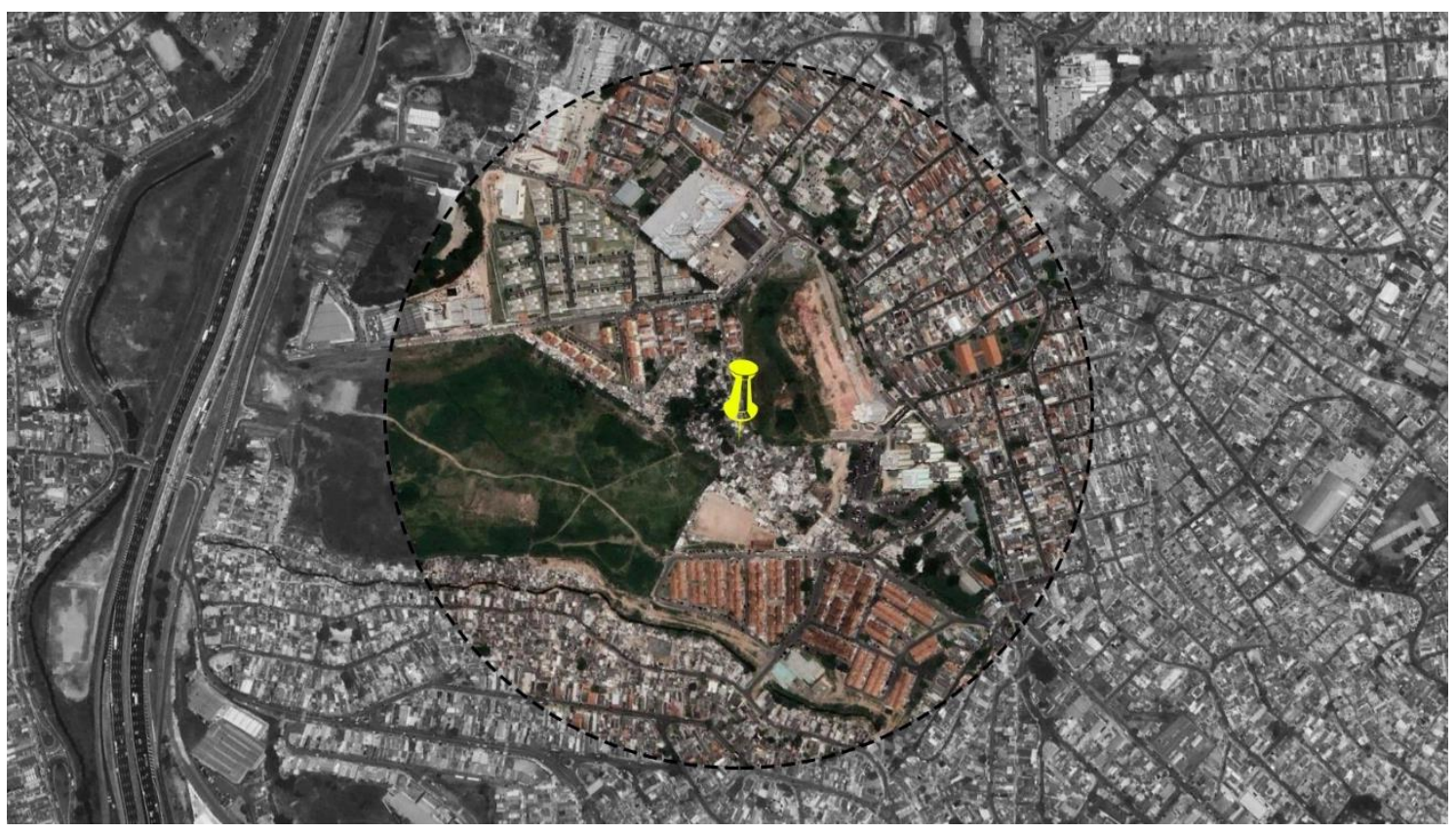

Fonte: Google Earth, editado pela autora

Figura 6: Imagens de satélite de Fazendinha de 2010 a 2017

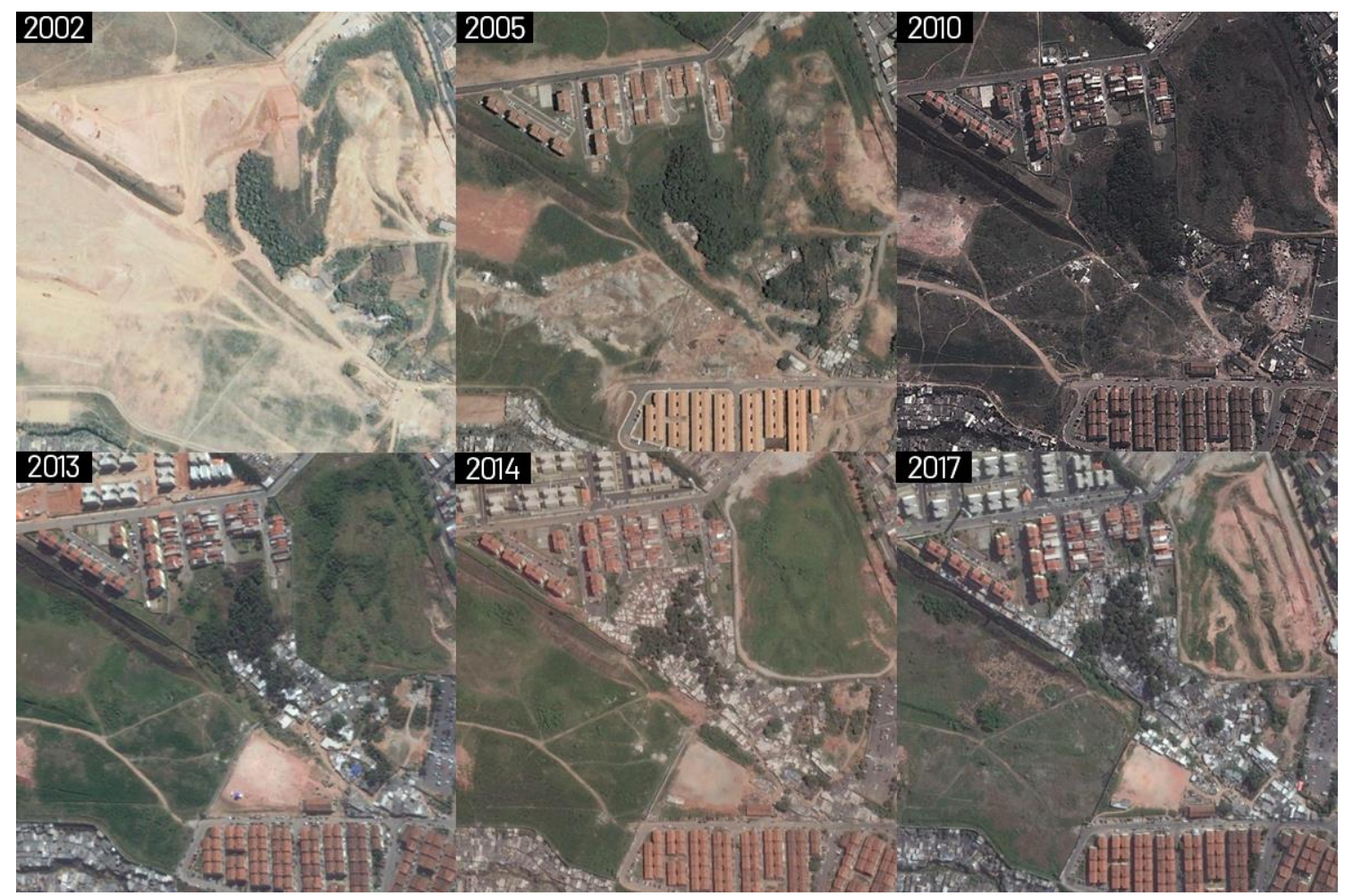

Fonte: Google Earth, editado pela autora 
Há um córrego que corta o interior da ocupação, além de linhas de alta tensão que atravessam parte do terreno. De uma maneira geral, as vias de acesso às moradias são pequenas vielas e não há possibilidade de entrada de veículos em nenhum ponto, exceto por regiões bem limítrofes ao assentamento.

Figura 7: Fazendinha - Detalhe do perímetro

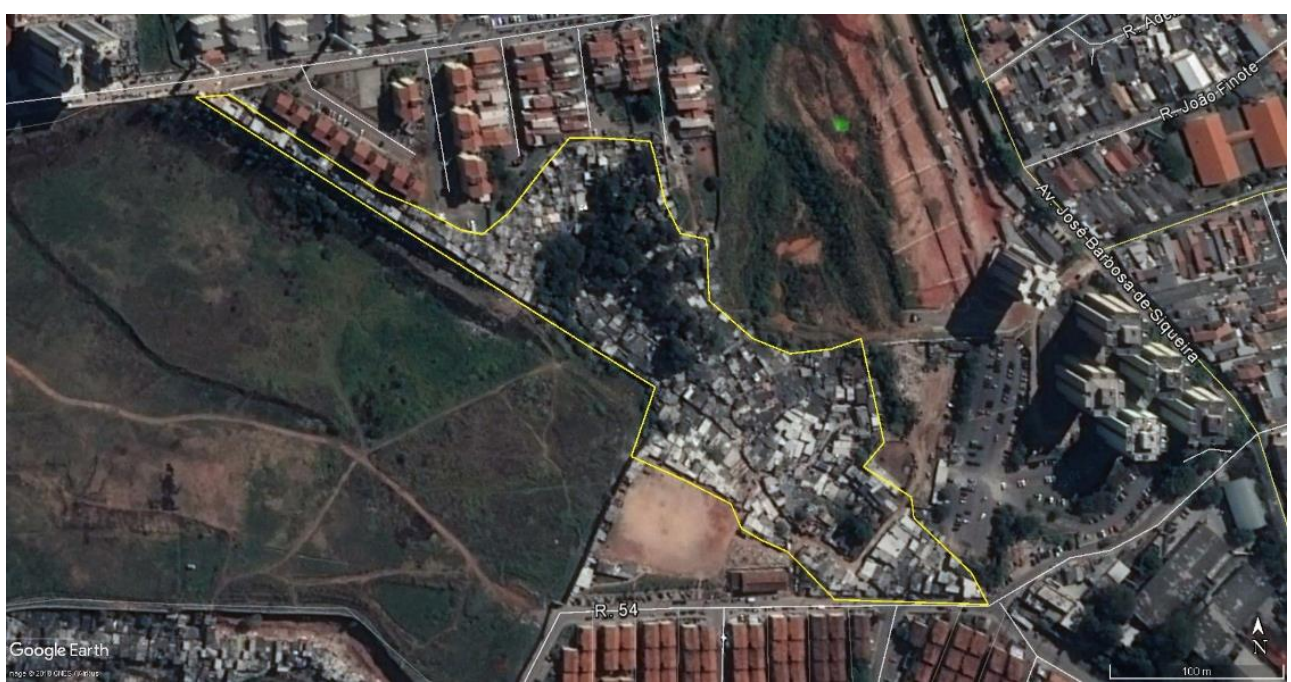

Fonte: Google Earth, editado pela autora

Figura 8: Fazendinha - Detalhe de vista interna de viela e córrego

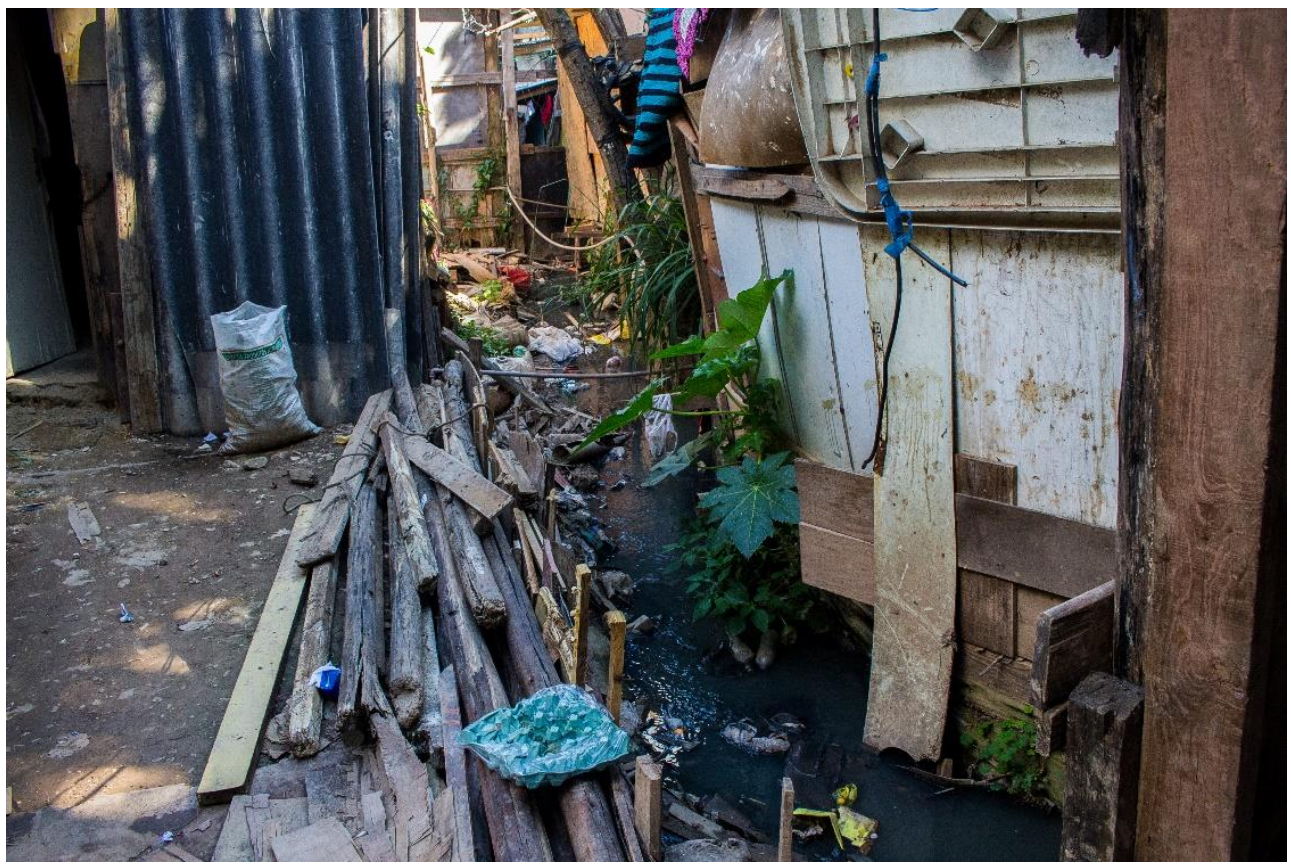

Fonte: TETO BRASIL 
Para o levantamento de dados feito em outubro de 2016, foi elaborado previamente um mapa ${ }^{7}$ que contabilizou um total de 751 construções. Nos dois dias de coleta de dados, ocorrida entre 8 e 9 de outubro de 2016, foram levantadas informações de 340 domicílios, o que gerou uma base de dados de 1092 pessoas, o que resultou numa média de 3,2 moradores por domicílio.

Em um cenário em que as 751 casas mapeadas estavam ocupadas, a partir da média de habitantes por casa e da área do terreno, calculou-se que a densidade populacional era de $706 \mathrm{hab} / \mathrm{ha}$. Se considerarmos que apenas as casas cujos moradores foram entrevistados, o número desce para 321 hab/ha.

Verificou-se que o tamanho das casas construídas é de $26 \mathrm{~m}^{2}$ em média, de que há 0,8 camas por pessoa, cálculo feito dividindo o número de lugares para dormir pelo número populacional, considerando uma cama de solteiro um espaço para dormir e uma cama de casal dois espaços.

No que diz respeito ao material utilizado para construir as casas na Fazendinha, a predominância é de retalhos de madeira, com 56\%, seguida de alvenaria, com $28 \%$, e madeira própria para construção, com $10 \%$.

Tabela 12: Fazendinha - Materialidade das moradias

\begin{tabular}{lcc}
\hline Materialidade das moradias & NA & $\%$ \\
\hline Casas de alvenaria/bloco & 94 & $28 \%$ \\
Madeira própria para construção & 33 & $10 \%$ \\
Retalhos de madeira & 190 & $56 \%$ \\
Misto & 3 & $1 \%$ \\
Outro & 20 & $5 \%$ \\
Total & 340 & $100 \%$ \\
\hline
\end{tabular}

Fonte: TETO BRASIL (2016)

Quanto à questão do abastecimento de água e do fornecimento de energia elétrica, quase que a totalidade das respostas apontou o uso de instalações irregulares, sendo 95\% para água e 98\% para a energia.

\footnotetext{
${ }^{7}$ Disponível nos anexos deste documento.
} 
Tabela 13: Fazendinha - Relação de posse com os terrenos

\begin{tabular}{lcc}
\hline Relação de posse com os terrenos & NA & $\%$ \\
\hline Terreno Próprio & 315 & $93 \%$ \\
Terreno Alugado & 1 & $0 \%$ \\
Terreno Emprestado & 15 & $2 \%$ \\
Outro & 5 & $1 \%$ \\
NS/NR & 4 & $1 \%$ \\
Total & 340 & $100 \%$ \\
\hline
\end{tabular}

Fonte: TETO BRASIL (2016)

Quando questionados a respeito da quantidade de dormitórios, a maior parte dos moradores afirmou ter apenas um dormitório em sua casa com um total de $56 \%$ das respostas, enquanto $24 \%$ das pessoas entrevistadas disseram não haver nenhum cômodo da casa como espaço exclusivo para dormir.

Tabela 14: Fazendinha - Quantidade de dormitórios

\begin{tabular}{lcc}
\hline Número de dormitórios & NA & $\%$ \\
\hline 0 Dormitórios & 81 & $24 \%$ \\
1 Dormitório & 190 & $56 \%$ \\
2 Dormitórios & 62 & $18 \%$ \\
3 Dormitórios & 6 & $2 \%$ \\
4 ou mais dormitórios & 0 & $0 \%$ \\
NS/NR & 1 & $0 \%$ \\
Total & 340 & $100 \%$ \\
\hline
\end{tabular}

Fonte: TETO BRASIL (2016)

Quanto à questão do abastecimento de água e do fornecimento de energia elétrica, quase que a totalidade das respostas foi de instalações irregulares, sendo 95\% para água e 98\% para a energia.

Tabela 15: Fazendinha - Abastecimento de água

\begin{tabular}{lcc}
\hline Abastecimento de água & NA & $\%$ \\
\hline Regular & 0 & $0 \%$ \\
Irregular & 322 & $95 \%$ \\
Ponto de água fora do terreno & 8 & $2 \%$ \\
Relógio de medição coletiva & 3 & $1 \%$ \\
Outros & 4 & $1 \%$ \\
NS/NR & 3 & $1 \%$ \\
Total & 340 & $100 \%$ \\
\hline
\end{tabular}

Fonte: TETO BRASIL (2016) 
Tabela 16: Fazendinha - Fornecimento de energia elétrica

\begin{tabular}{lcc}
\hline Fornecimento de energia elétrica & NA & $\%$ \\
\hline Regular & 4 & $1 \%$ \\
Irregular & 332 & $98 \%$ \\
Não possui & 1 & $0 \%$ \\
NS/NR & 3 & $1 \%$ \\
Total & 340 & $100 \%$ \\
\hline
\end{tabular}

Fonte: TETO BRASIL (2016)

Majoritariamente, conforme indicado por $76 \%$ das respostas, o esgoto das moradias da Fazendinha é despejado num córrego que corta a comunidade, enquanto 15\% afirmou fazer o despejo por meio da rede pública de esgoto.

Tabela 17: Fazendinha - Esgotamento sanitário

\begin{tabular}{lcc}
\hline Esgotamento sanitário & NA & $\%$ \\
\hline Rede pública de esgoto & 50 & $15 \%$ \\
A céu aberto (vai pro córrego) & 258 & $76 \%$ \\
Fossa(séptica ou não) & 14 & $4 \%$ \\
Não possui banheiro & 11 & $3 \%$ \\
Outros & 2 & $1 \%$ \\
NS/NR & 5 & $2 \%$ \\
Total & 340 & $100 \%$ \\
\hline
\end{tabular}

Fonte: TETO BRASIL (2016)

No que se refere ao descarte de lixo, $73 \%$ dos entrevistados afirmaram levar seu lixo para um ponto específico do assentamento, onde é realizada a coleta pela prefeitura da cidade; outros $13 \%$ disseram que a coleta é feita em frente à sua casa, enquanto 11\% declararam que, muitas vezes, o descarte é feito na rua ou em terrenos baldios próximos. 
Tabela 18: Fazendinha - Descarte de lixo

\begin{tabular}{lcc}
\hline Descarte de lixo & NA & $\%$ \\
\hline É coletado em frente de casa & 43 & $13 \%$ \\
Leva para um ponto de coleta & 261 & $73 \%$ \\
Joga na rua/terreno baldio & 39 & $11 \%$ \\
Joga no rio/córrego & 2 & $1 \%$ \\
Queima & 10 & $2 \%$ \\
NS/NR & 1 & $0 \%$ \\
Total & $356^{*}$ & $100 \%$ \\
\hline
\end{tabular}

* Houve múltiplas respostas nessa questão

Fonte: TETO Brasil (2016)

Sobre a composição social das 340 moradias entrevistadas, prevaleceu uma porcentagem maior de crianças com até 4 anos. As faixas etárias subsequentes, até os 19 anos, apresentam uma concentração significativamente reduzida. A segunda faixa etária que mais se sobressaiu foi a de 20 até 24 anos, seguida pela de 25 até 29 anos. Esses dados sugerem uma grande concentração de casais nessas faixas com filhos pequenos na composição familiar.

Gráfico 13: Fazendinha - Pirâmide etária

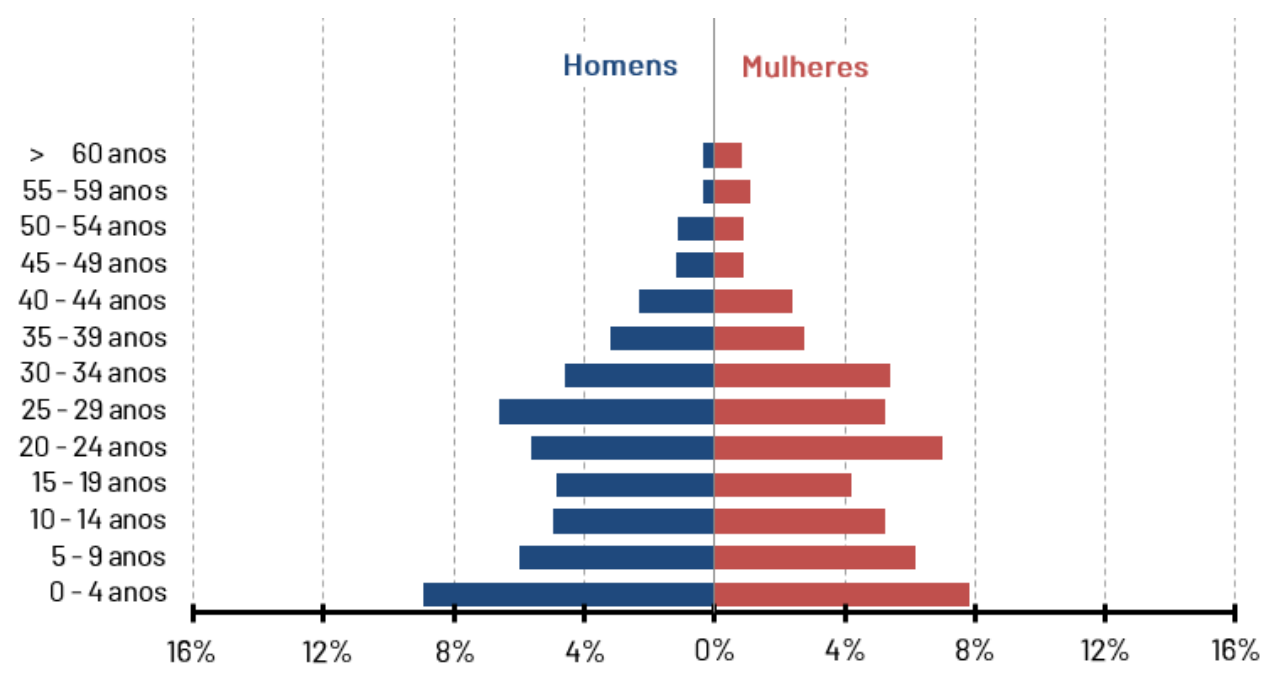

Fonte: TETO Brasil (2016)

No que diz respeito à procedência das pessoas que vivem na Fazendinha, 71\% delas afirmou ser nascida no estado de São Paulo, seguido do estado da Bahia, com $13 \%$ das respostas. A soma dos estados nordestinos representa $25 \%$ das respostas. 
Gráfico 14: Fazendinha - Procedência dos moradores

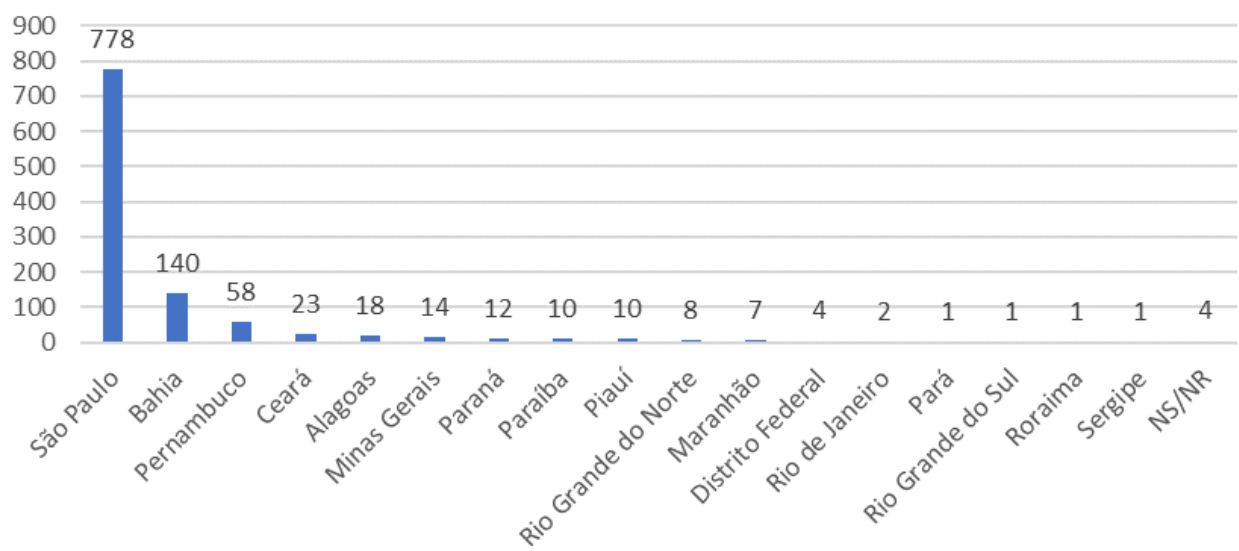

Fonte: Elaborado pela autora com base em TETO Brasil (2016)

Quando indagados sobre cor ou etnia com as quais se identificavam, mais da metade afirmou se considerar de cor parda, com $51 \%$, seguido de branca, com $26 \%$ das respostas, e preta com $21 \%$.

Tabela 19: Fazendinha - Autodeclaração de cor/etnia

\begin{tabular}{lcc}
\hline Cor/etnia & NA & $\%$ \\
\hline Preta & 227 & $21 \%$ \\
Branca & 287 & $26 \%$ \\
Parda & 557 & $51 \%$ \\
Amarela (oriental) & 7 & $1 \%$ \\
Indígena & 9 & $1 \%$ \\
NS/NR & 5 & $0 \%$ \\
Total & 1092 & $100 \%$ \\
\hline
\end{tabular}

Fonte: TETO Brasil(2016)

\subsection{Luiz Rubino, São Paulo, Zona Leste}

Luiz Rubino é uma favela localizada no extremo leste de São Paulo, distrito de Cidade Tiradentes, fazendo limite com o distrito de Guaianases e o município de Ferraz de Vasconcelos.

O terreno foi ocupado pelos primeiros moradores no ano de 2007 e seguiu se adensando até 2017 , quando aproximadamente 10,5 hectares de sua área já estava ocupada. Foi um assentamento que não sofreu nenhum grande pico de novos moradores, com um crescimento mais lento e gradual se comparado a outras favelas do mesmo período. 
Figura 9: Luiz Rubino - Localização

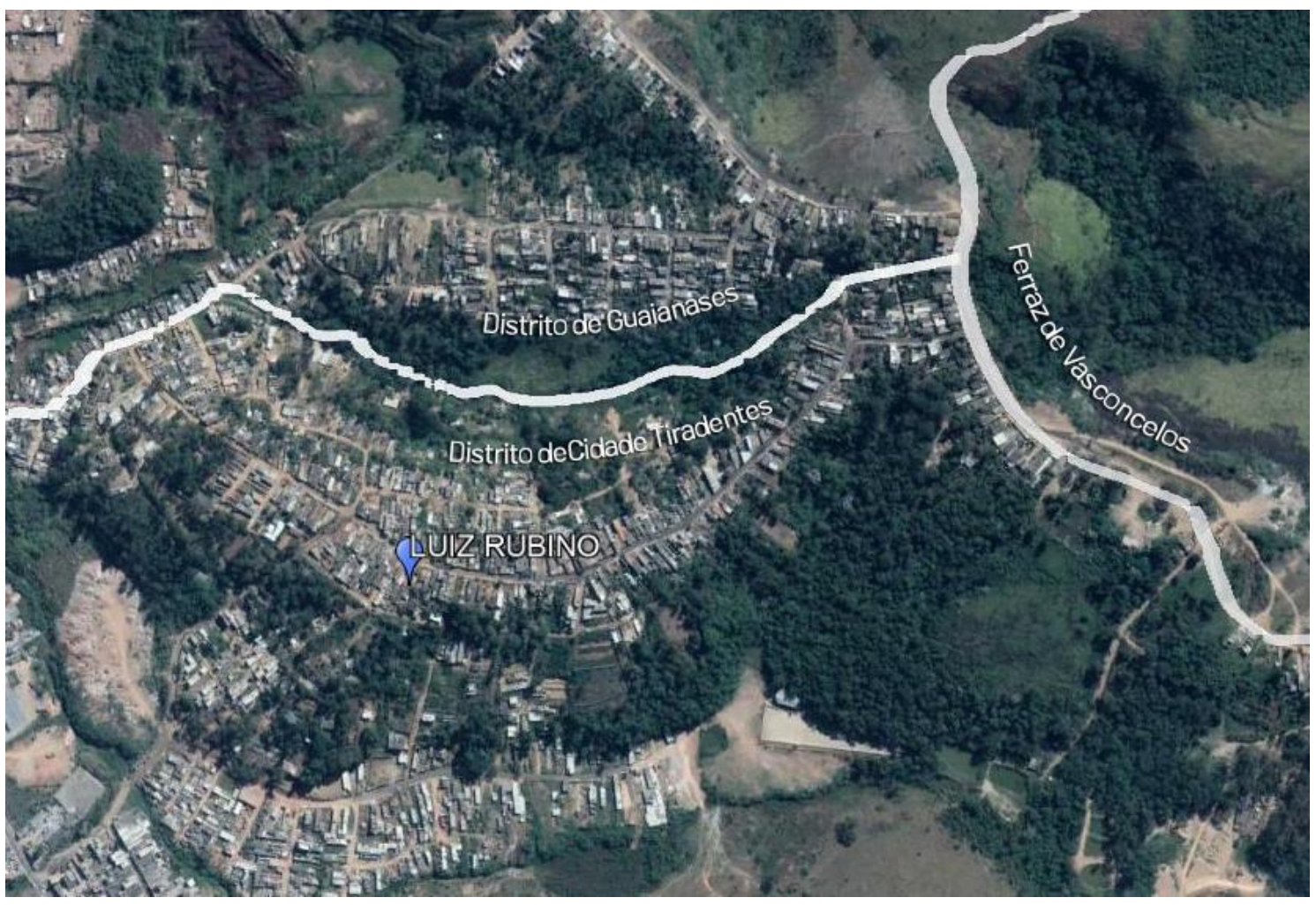

Fonte: Google Earth, editado pela autora

Figura 10: Foto comparativa de Luiz Rubino de 2010 a 2017

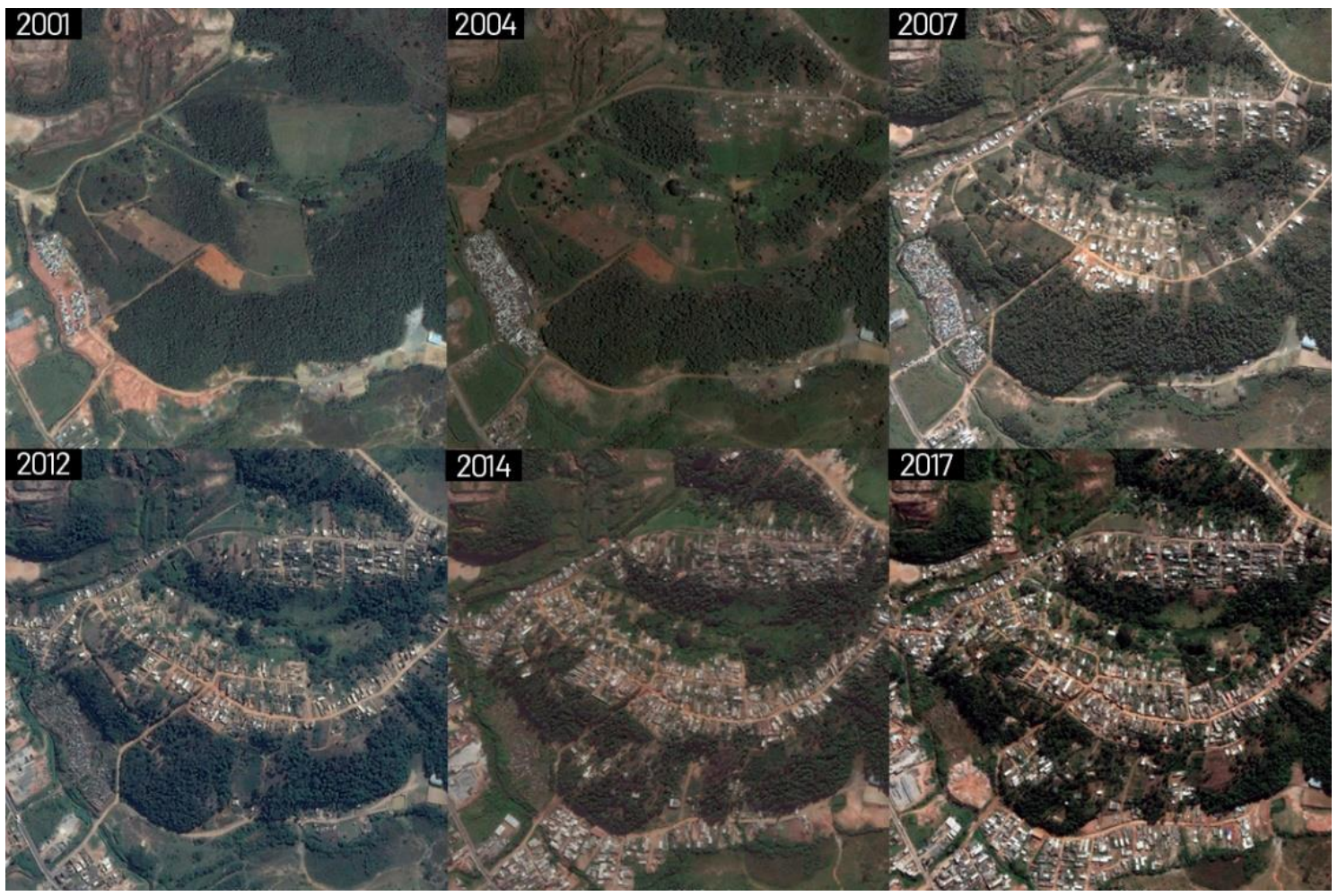

Fonte: Google Earth, editado pela autora 
A favela se formou ao longo de uma estrada de terra, estando a porção a norte numa ZEIS 1 e a porção a sul numa ZEIS 2. A diferença entre elas é que as ZEIS 1 são áreas caracterizadas pela presença de favelas e loteamentos irregulares, enquanto as ZEIS 2 predominam lotes e glebas não edificados ou subutilizados. Ambas têm como objetivo a promoção de moradia digna para a população de baixa renda.

No início da ocupação, o assentamento estava inserido em uma região com pouca infraestrutura, tornando mais difícil e demorado o acesso ao comércio e serviços públicos. Nos 10 anos seguintes, o entorno cresceu e se transformou, mas, ainda assim, em 2017, a conexão com o bairro e o acesso aos serviços ainda era deficiente. Para chegar ao ponto de ônibus mais próximo, era preciso caminhar 800 metros numa estrada de terra, além de atravessar um córrego por meio de uma ponte de madeira precariamente construída.

Figura 11: Luiz Rubino e o entorno imediato (raio de 500 metros)

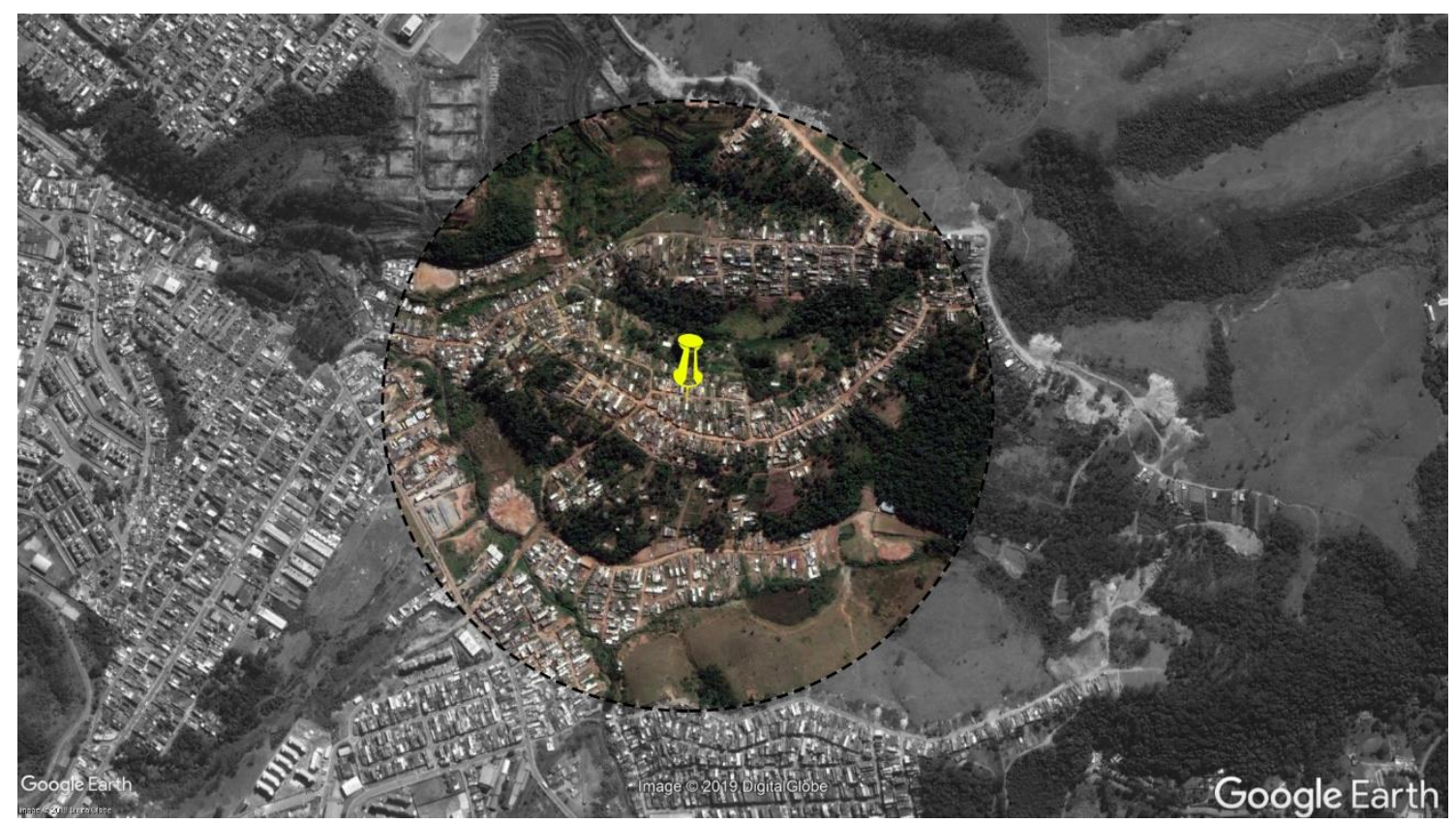

Fonte: Google Earth, editado pela autora

De maneira geral, as vias de acesso às moradias são vias largas que permitem a entrada de veículos, mas não são pavimentadas em nenhum ponto.

Para o levantamento de dados feito em agosto de 2017, foi elaborado previamente um mapa que contabilizou um total de 313 construções. Nos dois 
dias de coleta de dados, entre 5 e 6 de agosto de 2017, foram entrevistados 224 domićlios, o que gerou uma base de dados com informações de 729 moradores, resultando numa média de 3,2 moradores por domicílio.

No que diz respeito à densidade do assentamento, considerando um cenário em que as 313 casas mapeadas estão de fato ocupadas, a partir da média de habitantes por casa e da área do terreno, calculou-se que a densidade populacional era de $98 \mathrm{hab} / \mathrm{ha}$. Se considerarmos o cenário em que apenas as casas entrevistadas estão, de fato, ocupadas, o número cai para 69 hab/ha.

Verificou-se que o tamanho das casas construídas girava em torno de $42 \mathrm{~m}^{2}$. Além disso, também foi calculado o número de espaços para dormir. Considerando uma cama de solteiro um espaço e uma cama de casal dois espaços, dividindo pelo número populacional, o resultado foi uma média de 0,9 camas por pessoa.

No que diz respeito à materialidade das moradias na Luiz Rubino, a predominância é de casas de alvenaria, com 53\%, seguida de retalhos de madeira, com $29 \%$, e madeira própria para construção, com $10 \%$.

Tabela 20: Luiz Rubino - Materialidade das moradias

\begin{tabular}{lcc}
\hline Materialidade das moradias & NA & $\%$ \\
\hline Casas de alvenaria/bloco & 118 & $53 \%$ \\
Madeira própria para construção & 23 & $10 \%$ \\
Retalhos de madeira & 64 & $29 \%$ \\
Misto & 14 & $6 \%$ \\
Outro & 5 & $2 \%$ \\
Total & 224 & $100 \%$ \\
\hline
\end{tabular}

Fonte: TETO BRASIL (2017) 
Figura 12: Luiz Rubino - Vista do assentamento

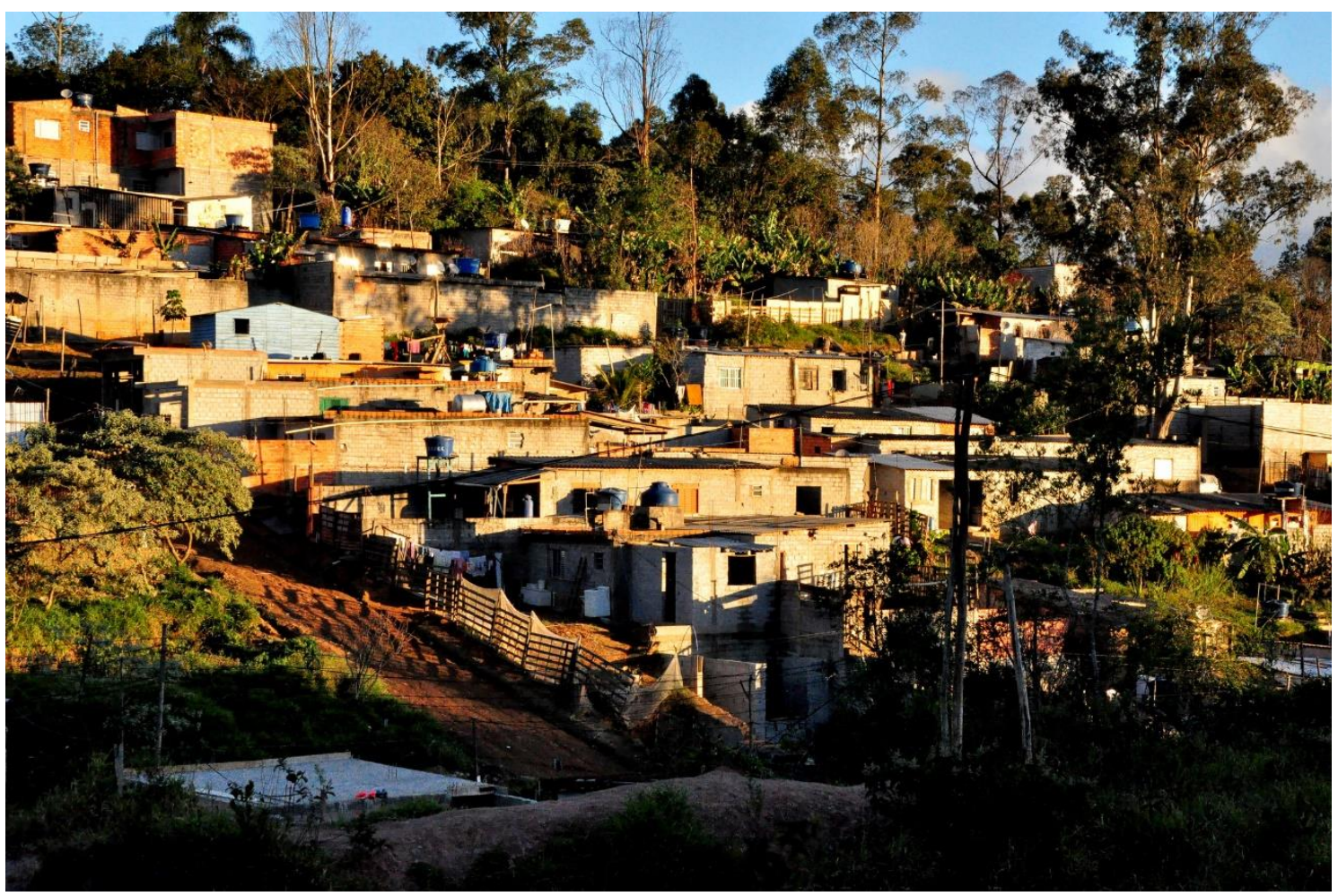

Fonte: TETO BRASIL

Figura 13: Luiz Rubino - Detalhe de moradia em madeira

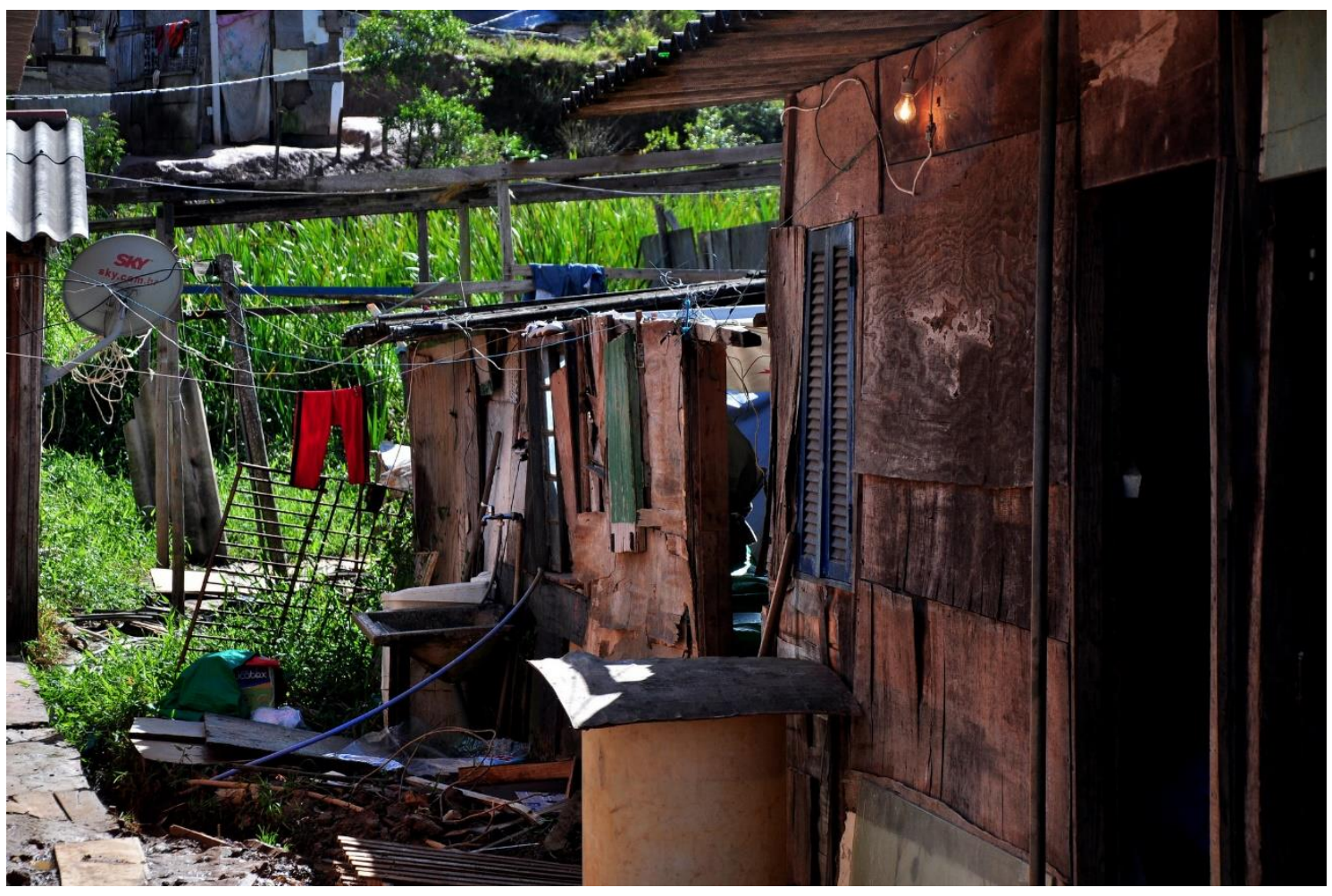

Fonte: TETO BRASIL 
Quanto à relação de posse com o terreno, 91\% dos moradores afirmaram ser donos de seus terrenos (ainda que não tenham a propriedade), enquanto $4 \%$ disseram ter alugado e outros $4 \%$ declararam estar com o terreno emprestado.

Tabela 21: Luiz Rubino - Relação de posse com o terreno

\begin{tabular}{lcc}
\hline $\begin{array}{l}\text { Relação de posse com o } \\
\text { terreno }\end{array}$ & NA & $\%$ \\
\hline Terreno Próprio & 201 & $91 \%$ \\
Terreno Alugado & 10 & $4 \%$ \\
Terreno Emprestado & 10 & $4 \%$ \\
Outro & 3 & $1 \%$ \\
NS/NR & 0 & $0 \%$ \\
Total & 224 & $100 \%$ \\
\hline
\end{tabular}

Fonte: TETO BRASIL (2017)

Quando questionados a respeito da quantidade de dormitórios, a maior parte dos moradores afirmou ter apenas um dormitório em sua casa, com um total de $50 \%$ das respostas, enquanto $27 \%$ das pessoas entrevistadas disseram não haver nenhum cômodo da casa como espaço exclusivo para dormir; outros 19\% responderam ter 2 dormitórios em suas casas; 3\% tinham 3 dormitórios; apenas $1 \%$ alegou ter mais de 4 dormitórios.

Tabela 22: Luiz Rubino - Quantidade de dormitórios

\begin{tabular}{lcc}
\hline Número de dormitórios & NA & $\%$ \\
\hline 0 Dormitórios & 61 & $27 \%$ \\
1 Dormitório & 112 & $50 \%$ \\
2 Dormitórios & 43 & $19 \%$ \\
3 Dormitórios & 6 & $3 \%$ \\
4 ou mais dormitórios & 2 & $1 \%$ \\
NS/NR & 0 & $0 \%$ \\
Total & 224 & $100 \%$ \\
\hline
\end{tabular}

Fonte: TETO BRASIL (2017)

Quanto à questão do abastecimento de água, 90\% das respostas alegaram ser irregular, 5\% afirmaram buscar água em um ponto fora do seu terreno, $3 \%$ disseram coletar água por meio de poço ou cisterna. 
Tabela 23: Luiz Rubino - Abastecimento de água

\begin{tabular}{lcc}
\hline Abastecimento de água & NA & $\%$ \\
\hline Regular & 0 & $0 \%$ \\
Irregular & 322 & $95 \%$ \\
Ponto de água fora do terreno & 8 & $2 \%$ \\
Relógio de medição coletiva & 3 & $1 \%$ \\
Outros & 4 & $1 \%$ \\
NS/NR & 3 & $1 \%$ \\
Total & 340 & $100 \%$ \\
\hline
\end{tabular}

Fonte: TETO BRASIL (2017)

No quesito fornecimento de energia elétrica, a grande maioria, com 96\% do total, disse ter instalado irregularmente, enquanto $2 \%$ afirmou não possuir.

Tabela 24: Luiz Rubino - Fornecimento de energia elétrica

\begin{tabular}{lcc}
\hline Fornecimento de energia elétrica & NA & $\%$ \\
\hline Regular & 1 & $0 \%$ \\
Irregular & 216 & $96 \%$ \\
Não possui & 5 & $2 \%$ \\
NS/NR & 2 & $1 \%$ \\
Total & 224 & $100 \%$ \\
\hline
\end{tabular}

Fonte: TETO BRASIL (2017)

Majoritariamente, o esgoto das moradias da Luiz Rubino é despejado no córrego que corta a comunidade (61\%), enquanto $21 \%$ afirmou utilizar o sistema de fossa para fazer o despejo e $9 \%$ disseram despejar diretamente no solo.

Tabela 25: Luiz Rubino - Esgotamento sanitário

\begin{tabular}{lcc}
\hline Esgotamento sanitário & NA & $\%$ \\
\hline Rede pública de esgoto & 1 & $0 \%$ \\
A céu aberto (vai pro córrego) & 137 & $61 \%$ \\
Fossa (séptica ou não) & 46 & $21 \%$ \\
Despejo no solo & 20 & $9 \%$ \\
Não possui banheiro & 15 & $7 \%$ \\
Outros & 0 & $0 \%$ \\
NS/NR & 5 & $2 \%$ \\
Total & 224 & $100 \%$ \\
\hline
\end{tabular}

Fonte: TETO BRASIL (2017)

No que se refere ao descarte de lixo, 96\% dos entrevistados afirmaram levar os rejeitos para um ponto específico do assentamento, onde é realizada a 
coleta pela prefeitura da cidade, e $4 \%$ afirmaram queimar o lixo ao invés de descartar.

Tabela 26: Luiz Rubino - Descarte de lixo

\begin{tabular}{lcc}
\hline Descarte de lixo & NA & $\%$ \\
\hline É coletado em frente de casa & 0 & $0 \%$ \\
Leva para um ponto de coleta & 213 & $96 \%$ \\
Joga na rua/terreno baldio & 2 & $1 \%$ \\
Joga no rio/córrego & 1 & $1 \%$ \\
Queima & 8 & $4 \%$ \\
NS/NR & 0 & $0 \%$ \\
Total & 224 & $100 \%$ \\
\hline
\end{tabular}

Fonte: TETO BRASIL (2017)

Sobre as características da composição social das 224 moradias entrevistadas, prevaleceu uma porcentagem maior de crianças até 4 anos, seguida pela de crianças com 5 a 9 anos. A terceira faixa etária que mais se sobressaiu foi a de 20 a 24, seguida pela de 25 a 29 anos, também quase empatada. Tal como na Fazendinha, esses números sugerem concentração de casais nessas faixas etárias com filhos pequenos na composição familiar. A particularidade da Luiz Rubino nesse quesito é que, a partir dos 40 anos, o número de pessoas diminui, mas de maneira menos drástica, percebendo-se um equilíbrio maior nas faixas etárias quando se compara ao gráfico da Fazendinha. Um dado que pode ser apontado como fora do padrão nessa comunidade é o desequilíbrio entre o sexo dos jovens de 10 a 14 anos - observa-se um número bem maior de mulheres, enquanto outras faixas mostram-se mais equilibradas. 
Gráfico 15: Luiz Rubino: pirâmide etária

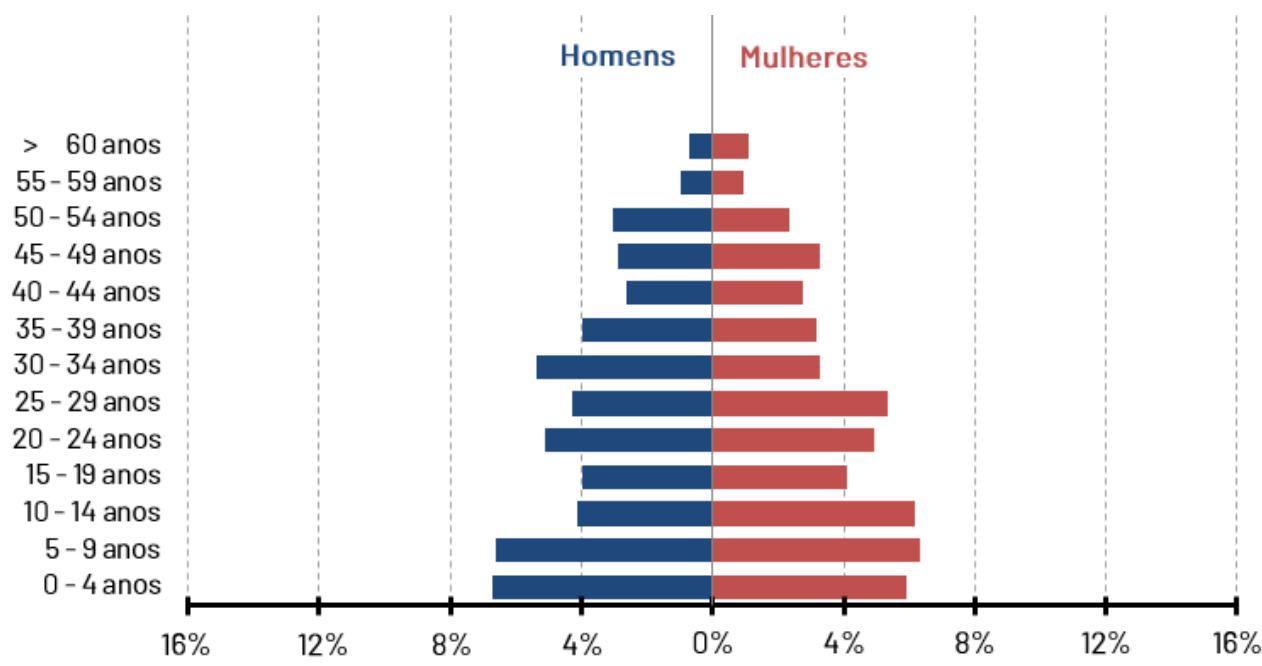

Fonte: Elaborado pela autora com base em TETO BRASIL (2017)

No que diz respeito à procedência das pessoas que vivem na Luiz Rubino, 67\% delas afirmaram ser nascidas no estado de São Paulo, seguida do estado da Bahia, com $12 \%$ das respostas. A soma dos estados nordestinos representa $28 \%$ das respostas.

Gráfico 16: Luiz Rubino - Procedência dos moradores

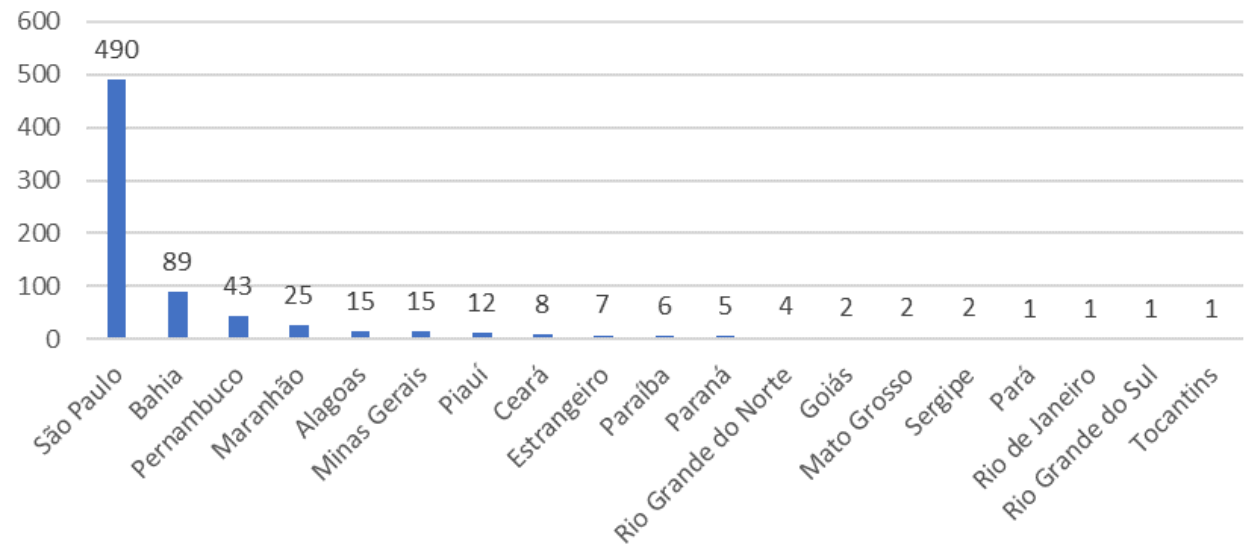

Fonte: TETO Brasil (2017)

Na questão sobre cor ou etnia, $45 \%$ se autodeclarou de cor parda, seguida de branca com $26 \%$ das respostas e preta com $21 \%$. 
Tabela 27: Luiz Rubino - Autodeclaração de cor/etnia

\begin{tabular}{lcc}
\hline Cor/etnia & NA & $\%$ \\
\hline Preta & 151 & $21 \%$ \\
Branca & 215 & $29 \%$ \\
Parda & 327 & $45 \%$ \\
Amarela (oriental) & 7 & $1 \%$ \\
Indígena & 15 & $2 \%$ \\
NS/NR & 14 & $2 \%$ \\
Total & 729 & $100 \%$ \\
\hline
\end{tabular}

Fonte: TETO BRASIL (2017)

\subsection{Pernilongo, São Paulo, Zona Norte}

Pernilongo é uma favela localizada na Zona Norte do município de São Paulo, na prefeitura regional de Casa Verde, mais precisamente no Distrito de Cachoeirinha. O terreno, de 0,4 hectares, está localizado em uma ZEIS 1, zoneamento caracterizado pela presença de favelas e loteamentos irregulares, e encontra-se inserido na malha urbana, com vias importantes nas adjacências, dotado de infraestrutura de transporte e equipamentos públicos próximos.

Figura 14: Pernilongo e o entorno imediato (raio de 500 metros)

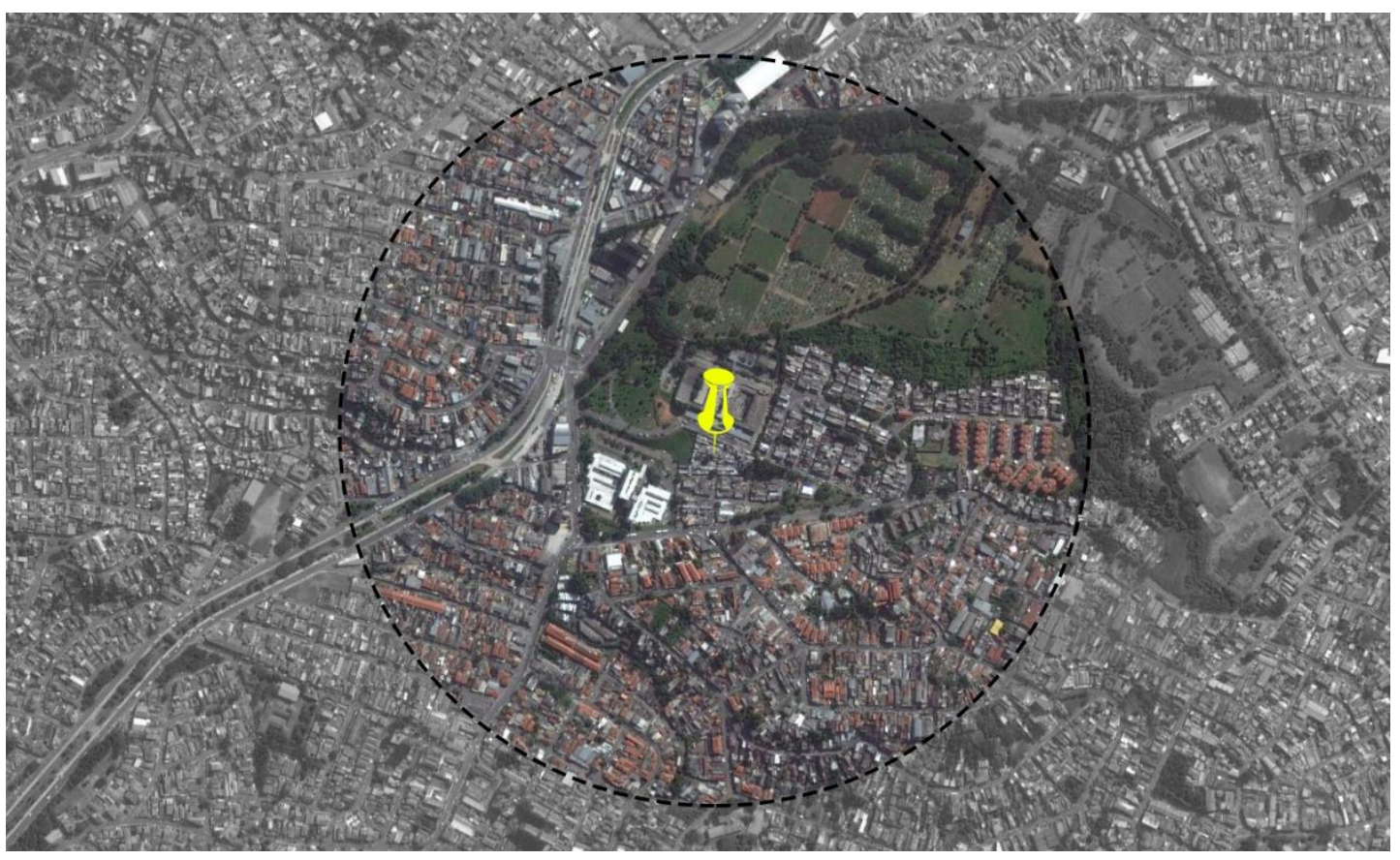

Fonte: Google Earth, editado pela autora 
Como é possível observar a partir da comparação de imagens de satélite de diferentes anos, o terreno foi completamente ocupado desde o início, não tendo o assentamento sofrido alterações quanto ao número de construções de 2014, quando surgiu, até 2017.

Figura 15: Foto comparativa de Pernilongo de 2013 a 2017

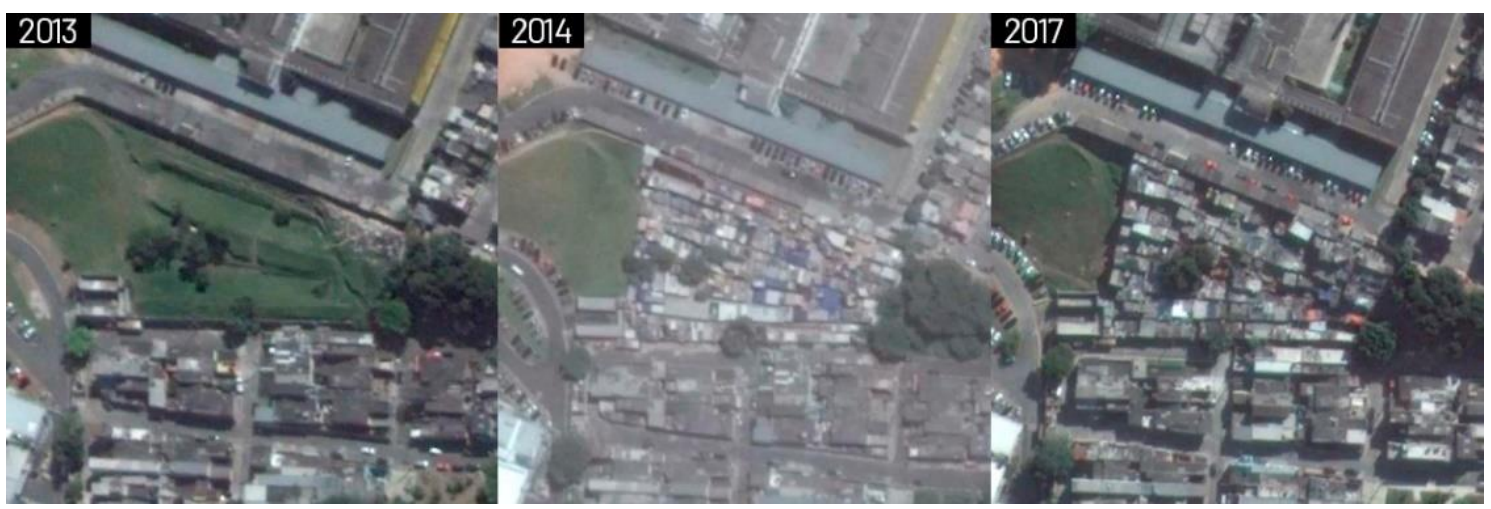

Fonte: Google Earth, editado pela autora

Pernilongo se formou por meio de iniciativa coletiva e é gerida com dinâmicas próprias do movimento social - não há comercialização de lotes e as famílias que ali moram foram previamente aprovadas pelos dirigentes.

Com alta densidade habitacional, as casas foram construídas sem recuos, e o acesso se dá por meio de vielas estreitas que só permitem o trânsito de pedestres no interior do assentamento.

O levantamento de dados foi realizado nos dias 27 e 28 de fevereiro de 2016 e, para isso, foi elaborado previamente um mapa que contabilizou um total de 136 construções. Dessas casas, 80 foram entrevistadas, o que gerou uma base de dados com informações de 212 moradores, resultando numa média de 2,6 moradores por domicílio.

Considerando um cenário em que as 136 casas mapeadas estavam, de fato, ocupadas, a partir da média de habitantes por casa e da área do terreno, calculou-se que a densidade populacional era de $924 \mathrm{hab} / \mathrm{ha}$. Se considerarmos o cenário em que apenas as 80 casas entrevistadas estavam ocupadas, o número desce para 533 hab/ha. 
Verificou-se também que o tamanho das casas construídas era de $19 \mathrm{~m}^{2}$, em média, e que o número de espaços para dormir girava em torno de 0,8 camas por pessoa.

Figura 16: Pernilongo - Vista de uma viela interna

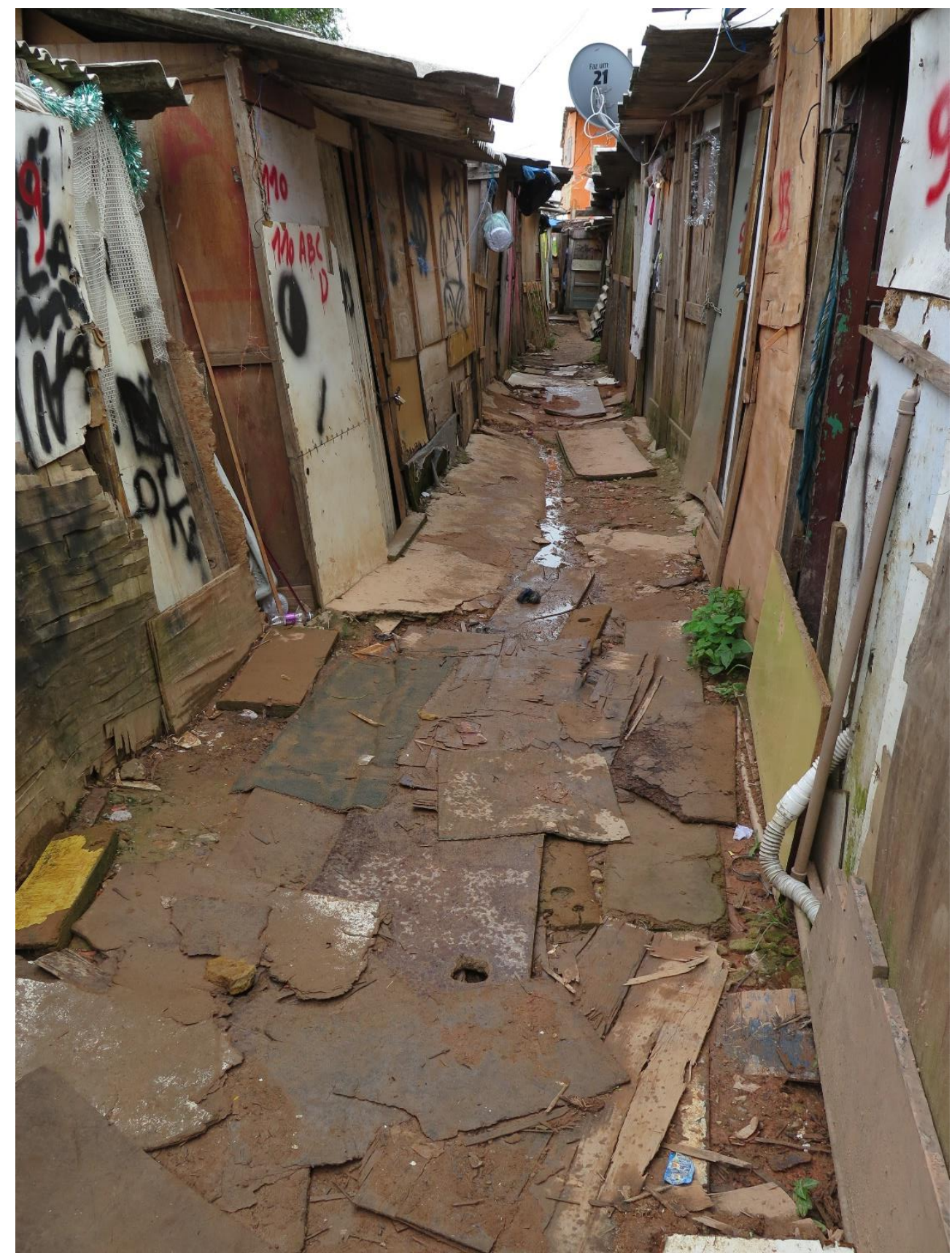

Fonte: TETO Brasil 
Quanto à materialidade das casas em Pernilongo, praticamente todas foram construídas a partir de retalhos de madeira, com 98\%.

Tabela 28: Pernilongo - Materialidade das moradias

\begin{tabular}{lcc}
\hline Materialidade das moradias & NA & $\%$ \\
\hline Casas de alvenaria/bloco & 0 & $0 \%$ \\
Madeira própria para construção & 0 & $0 \%$ \\
Retalhos de madeira & 78 & $98 \%$ \\
Misto & 0 & $0 \%$ \\
Outro & 2 & $2 \%$ \\
Total & 80 & $100 \%$ \\
\hline
\end{tabular}

Fonte: TETO BRASIL(2016)

Quanto à situação do terreno, 94\% dos moradores se encaixavam na situação de terreno próprio, ainda que irregular, enquanto 5\% afirmaram estar com o terreno emprestado e apenas $1 \%$ alugado.

Tabela 29: Pernilongo - Relação de posse com o terreno

\begin{tabular}{lcc}
\hline $\begin{array}{l}\text { Relação de posse com o } \\
\text { terreno }\end{array}$ & NA & $\%$ \\
\hline Terreno Próprio & 75 & $94 \%$ \\
Terreno Alugado & 1 & $1 \%$ \\
Terreno Emprestado & 4 & $5 \%$ \\
Outro & 0 & $0 \%$ \\
NS/NR & 0 & $0 \%$ \\
Total & 80 & $100 \%$ \\
\hline
\end{tabular}

Fonte: TETO BRASIL (2016)

Quanto ao número de dormitórios, a maior parte dos moradores afirmou ter apenas um, totalizando $80 \%$ das respostas, enquanto 19\% disseram ter dois cômodos para dormir. No questionário aplicado nessa ocasião, não havia a opção de "0 dormitórios" - dessa forma, mesmo moradias com um único cômodo foram consideradas na pesquisa com "1 dormitório". Faz-se necessário reforçar que 35\% das casas de Pernilongo são de apenas um cômodo, ou seja, pelo menos um terço da comunidade não possui um cômodo exclusivo para dormir. 
Tabela 30: Pernilongo - Quantidade de dormitórios por casa

\begin{tabular}{lcc}
\hline Número de dormitórios & NA & $\%$ \\
\hline 1 Dormitório & 64 & $80 \%$ \\
2 Dormitórios & 15 & $19 \%$ \\
3 Dormitórios & 1 & $2 \%$ \\
4 ou mais dormitórios & 0 & $0 \%$ \\
NS/NR & 0 & $0 \%$ \\
Total & 80 & $100 \%$ \\
\hline
\end{tabular}

Fonte: TETO BRASIL (2016)

Tabela 31: Pernilongo - Quantidade de cômodos por casa

\begin{tabular}{lcc}
\hline Número de dormitórios & NA & $\%$ \\
\hline 1 Cômodo & 28 & $35 \%$ \\
2 Cômodos & 29 & $36 \%$ \\
3 Cômodos & 18 & $23 \%$ \\
4 Cômodos & 4 & $5 \%$ \\
5 Cômodos & 1 & $1 \%$ \\
Total & 80 & $100 \%$ \\
\hline
\end{tabular}

Fonte: TETO BRASIL (2016)

Em relação ao abastecimento de água, 89\% das respostas apontaram instalações irregulares, $4 \%$ indicaram a utilização de um ponto de água da comunidade, enquanto 5\% sinalizaram ter acesso de outras maneiras.

Tabela 32: Pernilongo - Abastecimento de água

\begin{tabular}{lcc}
\hline Abastecimento de água & NA & $\%$ \\
\hline Regular & 1 & $1 \%$ \\
Irregular & 71 & $89 \%$ \\
Ponto de água fora do terreno & 3 & $4 \%$ \\
Relógio de medição coletiva & 0 & $0 \%$ \\
Outros & 4 & $5 \%$ \\
NS/NR & 1 & $1 \%$ \\
Total & 80 & $100 \%$ \\
\hline
\end{tabular}

Fonte: TETO BRASIL (2016)

Quanto ao fornecimento de energia elétrica, quase que a totalidade das respostas foi de instalações irregulares com $98 \%$ das respostas. 
Tabela 33: Pernilongo - Fornecimento de energia elétrica

\begin{tabular}{lcc}
\hline Fornecimento de energia elétrica & NA & $\%$ \\
\hline Regular & 1 & $1 \%$ \\
Irregular & 78 & $98 \%$ \\
Não possui & 0 & $0 \%$ \\
NS/NR & 1 & $1 \%$ \\
Total & 80 & $100 \%$ \\
\hline
\end{tabular}

Fonte: TETO BRASIL (2016)

No que diz respeito ao esgotamento sanitário, as respostas foram variadas. Dos entrevistados, $40 \%$ afirmaram ter realizado ligação com a rede de esgoto pública existente, $27 \%$ disseram fazer uso de fossa em seus terrenos, $20 \%$ não possuíam banheiro próprio, enquanto apenas $8 \%$ afirmaram despejar seus resíduos a céu aberto.

Tabela 34: Pernilongo - Esgotamento sanitário

\begin{tabular}{lcc}
\hline Esgotamento sanitário & NA & $\%$ \\
\hline Rede pública de esgoto & 32 & $40 \%$ \\
A céu aberto (vai pro córrego) & 6 & $8 \%$ \\
Fossa(séptica ou não) & 22 & $27 \%$ \\
Não possui banheiro & 16 & $20 \%$ \\
Outros & 4 & $5 \%$ \\
NS/NR & 0 & $0 \%$ \\
Total & 80 & $100 \%$ \\
\hline
\end{tabular}

Fonte: TETO BRASIL (2016)

Já no quesito descarte de lixo, 97\% disseram levar seu lixo até o ponto de coleta. Os outros 3\% não souberam ou não quiseram responder.

Tabela 35: Pernilongo - Forma de descarte de lixo

\begin{tabular}{lcc}
\hline Descarte de lixo & NA & $\%$ \\
\hline É coletado em frente de casa & 0 & $0 \%$ \\
Leva para um ponto de coleta & 78 & $97 \%$ \\
Joga na rua/terreno baldio & 0 & $0 \%$ \\
Joga no rio/córrego & 0 & $0 \%$ \\
Queima & 0 & $0 \%$ \\
NS/NR & 2 & $3 \%$ \\
Total & 80 & $100 \%$ \\
\hline
\end{tabular}

Fonte: TETO BRASIL (2016) 
$\mathrm{Na}$ comunidade Pernilongo, prevaleceu uma porcentagem maior de crianças até 4 anos, totalizando $13 \%$ da população, com destaque para o sexo feminino nessas idades específicas. As outras duas faixas etárias que mais se destacaram foram as de 15 a 19 e de 20 a 24 anos, ambas com $12 \%$ cada. Nessas faixas, o sexo se mostrou equilibrado, o que mais uma vez sugere grande concentração de casais jovens com filhos pequenos na composição familiar.

Gráfico 17: Pernilongo - Pirâmide etária

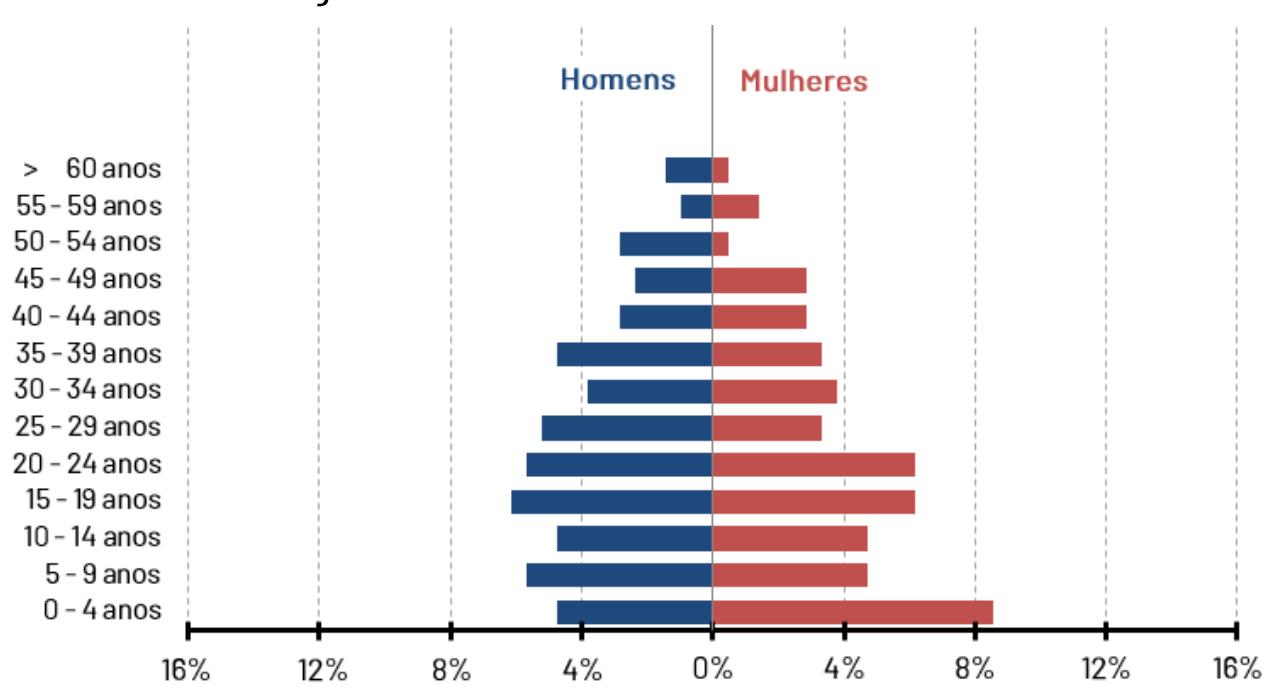

Fonte: Elaborado pela autora a partir de dados do TETO Brasil (2016)

Quanto à procedência das pessoas que viviam em Pernilongo, 73\% nasceram no estado de São Paulo, enquanto 8\% na Bahia e 7\% em Alagoas. A soma de todos os procedentes nordestinos totalizou $21 \%$ das respostas. 
Gráfico 18: Pernilongo - Procedência dos moradores por unidade de federação

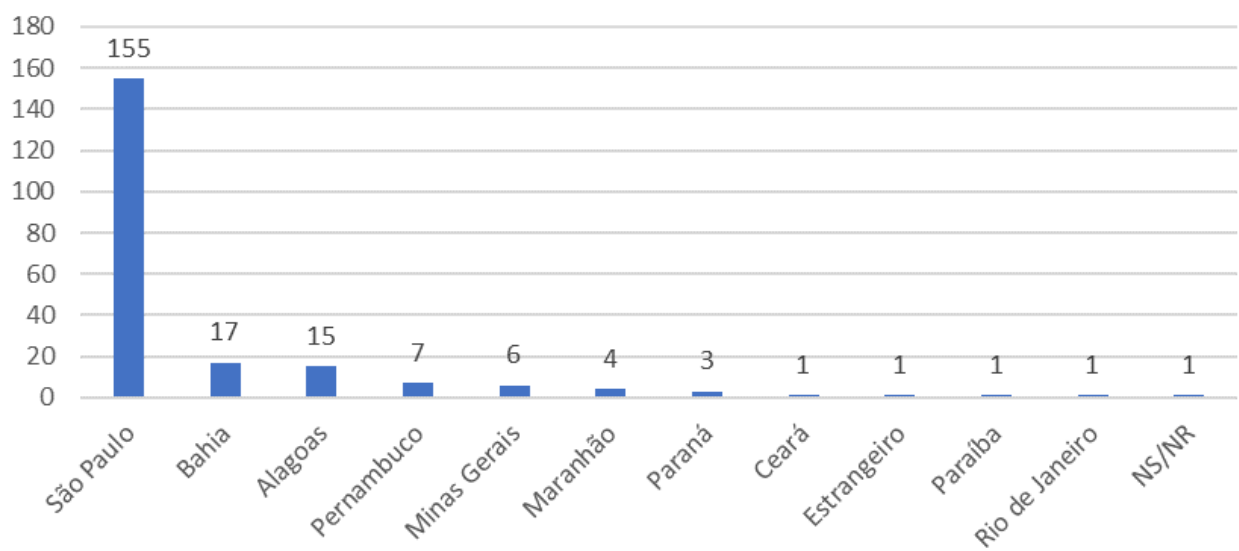

Fonte: Elaborado pela autora a partir de dados do TETO Brasil (2016)

Quando indagados sobre a cor ou etnia com a qual se identificavam, 41\% se declarou de cor parda, seguida de 33\% de cor preta, e 26\% de cor de branca. Pretos e pardos, somados, totalizavam $74 \%$ da população.

Tabela 36: Pernilongo - Autodeclaração de cor/etnia

\begin{tabular}{lcc}
\hline Cor/etnia & NA & $\%$ \\
\hline Preta & 69 & $33 \%$ \\
Branca & 55 & $26 \%$ \\
Parda & 87 & $41 \%$ \\
Amarela (oriental) & 1 & $0 \%$ \\
Indígena & 0 & $0 \%$ \\
NS/NR & 0 & $0 \%$ \\
Total & 212 & $100 \%$ \\
\hline
\end{tabular}

Fonte: TETO BRASIL(2016)

\subsection{Olga Benário, São Paulo, Zona Sul}

Olga Benário é uma favela localizada na Zona Sul do município de São Paulo, na prefeitura regional de Campo Limpo, mais precisamente no Distrito de Capão Redondo. Com um entorno já consolidado, o terreno de aproximadamente 40 hectares está inserido numa ZEIS 2, zona que prevê a demarcação de lotes vazios ou subutilizados para promoção de habitação de interesse social. 
Figura 17: Olga Benário e o entorno imediato (raio de 500 metros)

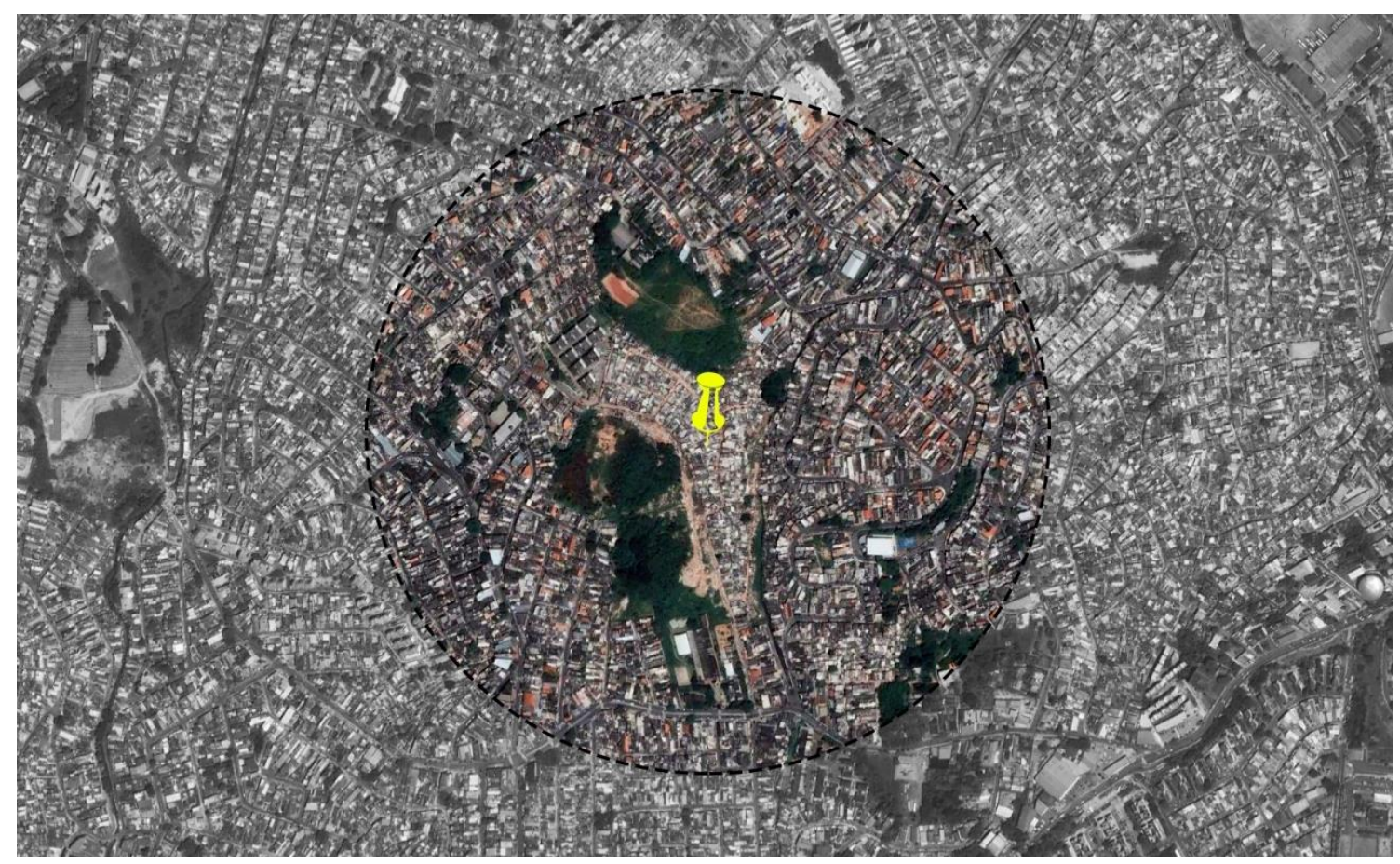

Fonte: Google Earth, editado pela autora

Anterior a 2010, há 3 imagens de satélite disponíveis no Google Earth. A primeira é de 2002, e o terreno aparece vazio; nas outras duas, de 2008 e 2009 , ele aparece completamente ocupado. Em seguida, em 2010, a imagem demonstra que houve remoção de todas as moradias e o terreno permaneceu vazio até 2014, quando voltou a ser ocupado. O assentamento se formou logo após a aprovação do Plano Diretor, em 2014, por meio de iniciativa coletiva. Percebe-se que o terreno foi praticamente todo ocupado já no ano de 2014, tendo sofrido apenas um aumento na densidade das moradias nos anos seguintes.

Em Olga Benário não há comercialização dos lotes e as famílias que ali moram passam, primeiramente, por uma aprovação dos dirigentes. 
Figura 18: Foto comparativa do terreno de Olga Benário de 2002 a 2017

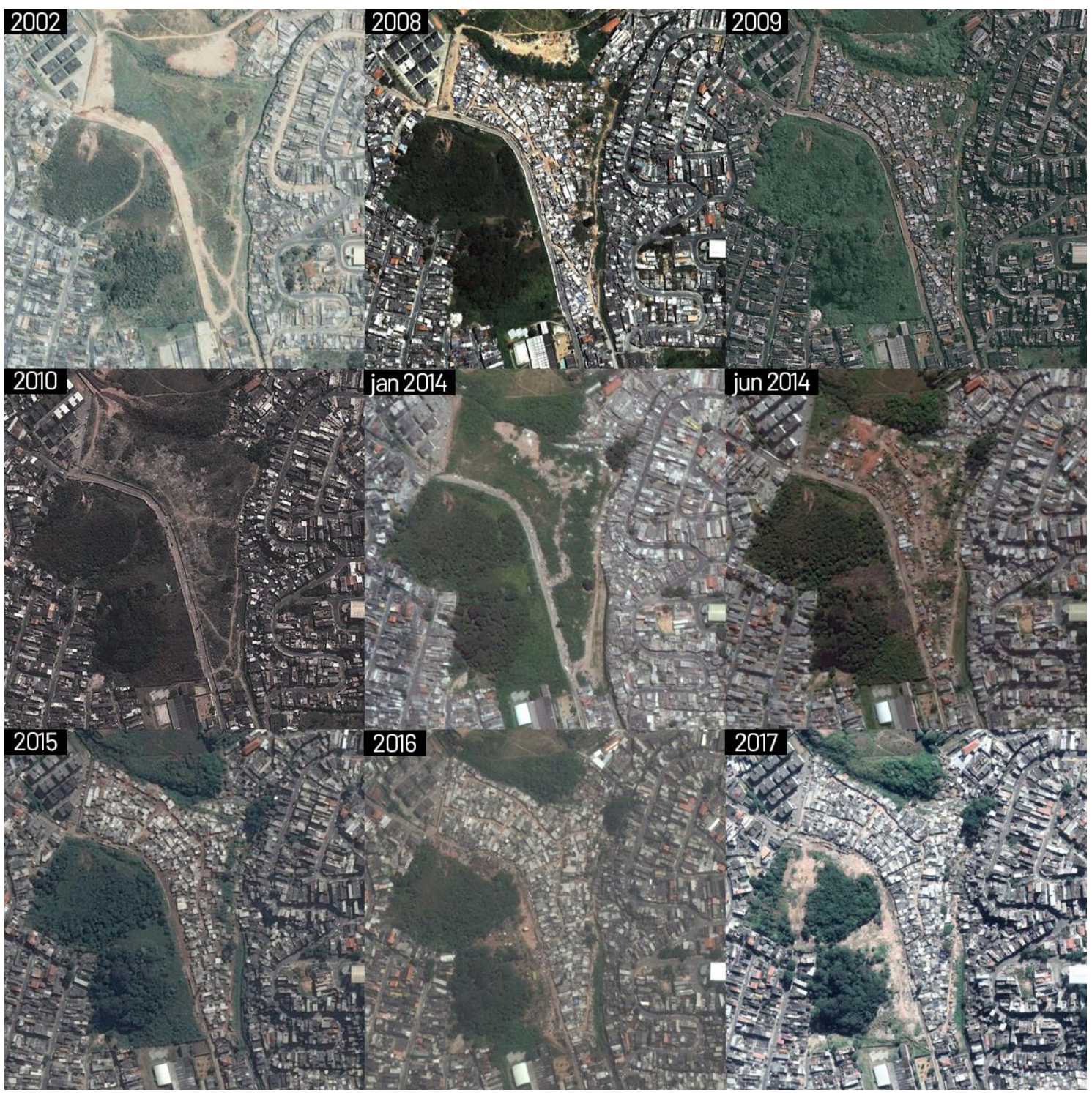

Fonte: Google Earth, editado pela autora

Observa-se também que as principais vias internas do assentamento são largas e permitem trânsito de automóveis. No entanto, alguns pontos só são acessíveis por meio de vielas. As casas foram construídas sem recuos e muitas contam com mais de um pavimento. 
Figura 19: Olga Benário - Detalhe de vista da ocupação

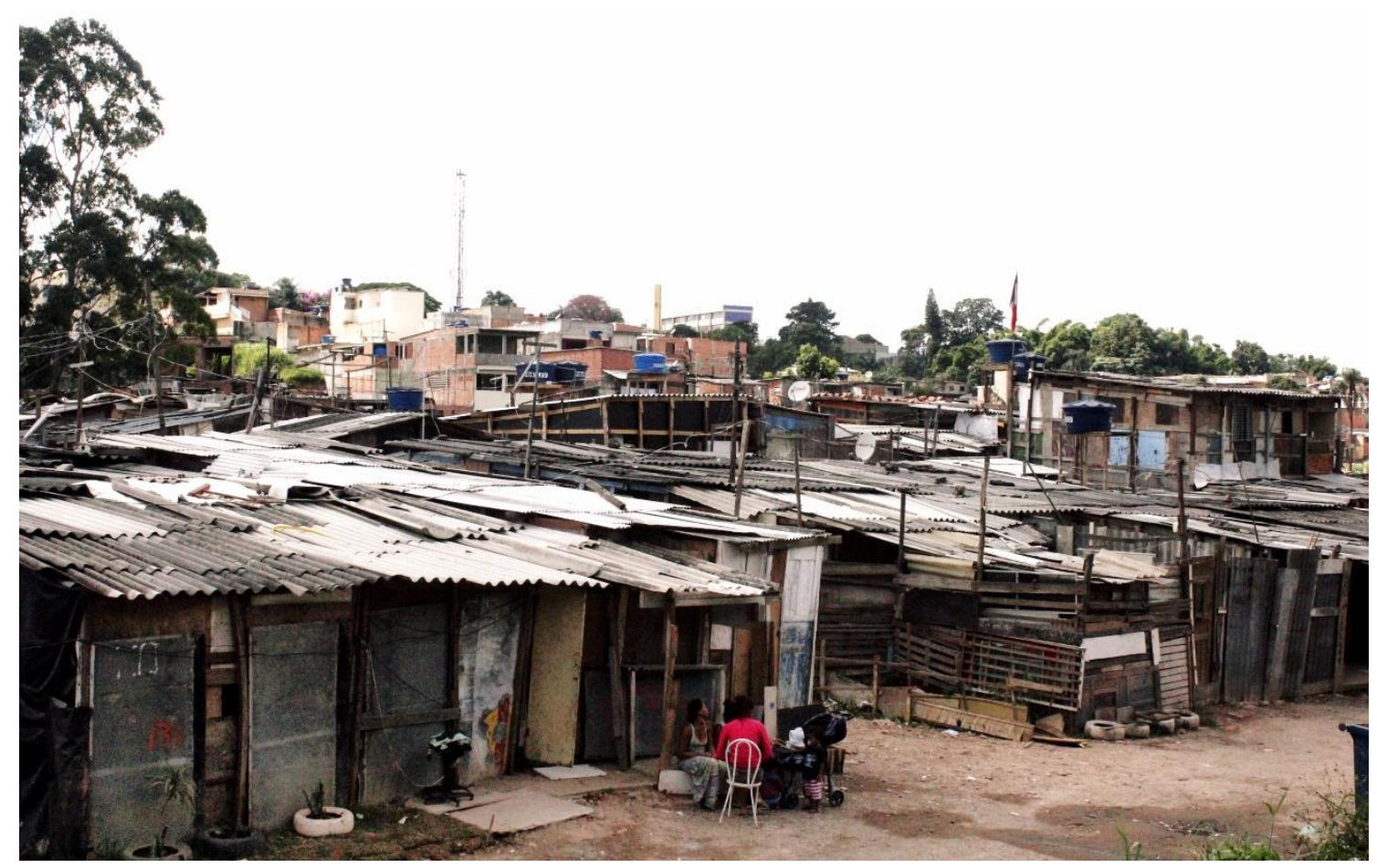

Fonte: TETO BRASIL

Figura 20: Olga Benário - Vista da via principal

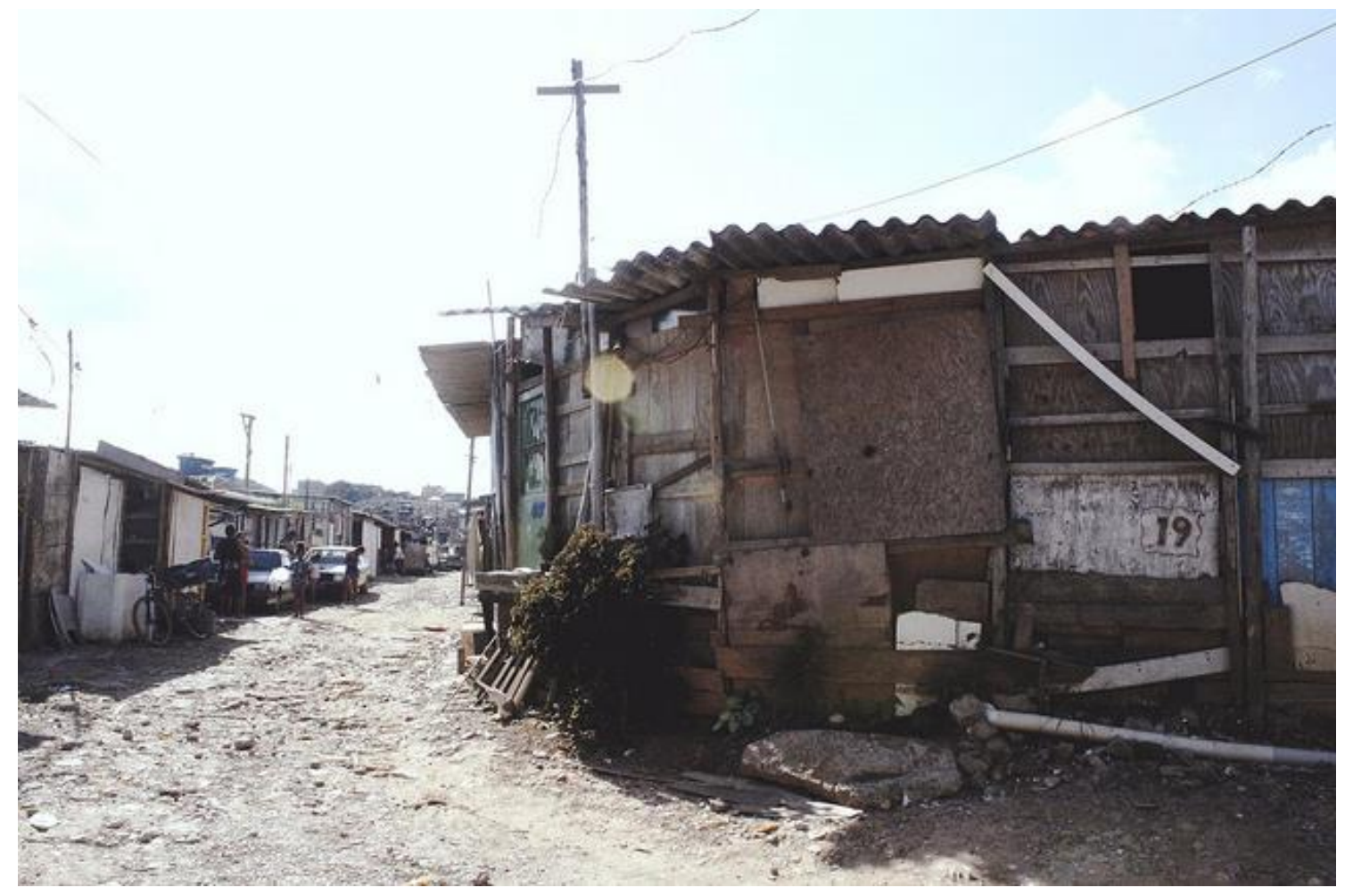

Fonte: TETO BRASIL 
Para realizar o levantamento de dados nos dias 25 e 26 de março de 2017 , foi elaborado previamente um mapa que contabilizou um total de 646 construções. Foram entrevistados 413 domicílios, o que gerou uma base de dados com informações de 1195 moradores, resultando numa média de 2,9 moradores por domicílio.

Considerando um cenário em que as 646 casas mapeadas estão de fato ocupadas, a partir da média de habitantes por casa e da área do terreno, calculouse que a densidade populacional é de $468 \mathrm{hab} / \mathrm{ha}$. Se considerarmos o cenário em que apenas as casas entrevistadas estão, de fato, ocupadas, o número cai para 300 hab/ha. O tamanho médio das casas construídas em Olga Benário é de $36 \mathrm{~m}^{2}$ e o número de lugares para dormir é de 0,9 camas por pessoa.

No que diz respeito ao material utilizado para a construção das moradias, a maior parte, com $83 \%$ das respostas, utilizou retalhos de madeira, enquanto $10 \%$ madeira própria para construção, $3 \%$ material misto e só $2 \%$ alvenaria.

Tabela 37: Olga Benário - Materialidade das moradias

\begin{tabular}{lcc}
\hline Materialidade das moradias & NA & $\%$ \\
\hline Casas de alvenaria/bloco & 8 & $2 \%$ \\
Madeira própria para construção & 41 & $10 \%$ \\
Retalhos de madeira & 341 & $83 \%$ \\
Misto & 16 & $3 \%$ \\
Outro & 7 & $2 \%$ \\
Total & 413 & $100 \%$ \\
\hline
\end{tabular}

Fonte: TETO BRASIL (2017)

Quanto à situação do terreno, 96\% dos moradores se encaixam na situação de terreno próprio, ainda que irregular, enquanto 3\% afirmaram estar com o terreno emprestado e apenas 1\% em outras situações. 
Tabela 38: Olga Benário - Relação de posse com o terreno

\begin{tabular}{lcc}
\hline $\begin{array}{l}\text { Relação de posse com o } \\
\text { terreno }\end{array}$ & NA & $\%$ \\
\hline Terreno Próprio & 395 & $96 \%$ \\
Terreno Alugado & 1 & $0 \%$ \\
Terreno Emprestado & 13 & $3 \%$ \\
Outro & 4 & $1 \%$ \\
NS/NR & 0 & $0 \%$ \\
Total & 413 & $100 \%$ \\
\hline
\end{tabular}

Fonte: TETO BRASIL (2017)

Quanto ao número de dormitórios, a maior parte dos moradores afirmou ter apenas um, totalizando $64 \%$ dos domicílios, enquanto $18 \%$ não tinham nenhum cômodo destinado exclusivamente para dormir e 17\% das casas contavam com dois.

Tabela 39: Olga Benário - Quantidade de dormitórios por casa

\begin{tabular}{lcc}
\hline Número de dormitórios & NA & $\%$ \\
\hline 0 Dormitórios & 75 & $18 \%$ \\
\hline 1 Dormitório & 264 & $64 \%$ \\
2 Dormitórios & 29 & $17 \%$ \\
3 Dormitórios & 3 & $1 \%$ \\
4 ou mais dormitórios & 2 & $0 \%$ \\
NS/NR & 0 & $0 \%$ \\
Total & 413 & $100 \%$ \\
\hline
\end{tabular}

Fonte: TETO BRASIL (2017)

Quanto ao uso de água, a grande maioria afirmou ter abastecimento irregular, com $87 \%$ das respostas, enquanto $7 \%$ disse se abastecer por meio de um ponto externo à sua casa.

Tabela 40: Olga Benário - Abastecimento de água

\begin{tabular}{lcc}
\hline Abastecimento de água & NA & $\%$ \\
\hline Regular & 5 & $1 \%$ \\
Irregular & 361 & $87 \%$ \\
Poço, cisterna no terreno & 2 & $0 \%$ \\
Ponto de água fora do terreno & 29 & $7 \%$ \\
Relógio de medição coletiva & 4 & $1 \%$ \\
Outros & 3 & $1 \%$ \\
NS/NR & 9 & $3 \%$ \\
Total & 413 & $100 \%$ \\
\hline
\end{tabular}


Também quanto à energia elétrica, a maioria das respostas apontou fornecimento irregular, com $93 \%$ do total, enquanto 3\% disseram estar em situação regular; outros $2 \%$ apontaram outras fontes e $1 \%$ alegou não possuir energia elétrica em suas casas.

Tabela 41: Olga Benário - Fornecimento de energia elétrica

\begin{tabular}{lcc}
\hline Fornecimento de energia elétrica & NA & $\%$ \\
\hline Regular & 11 & $3 \%$ \\
Irregular & 387 & $93 \%$ \\
Outra fonte & 7 & $2 \%$ \\
Não possui & 3 & $1 \%$ \\
NS/NR & 5 & $1 \%$ \\
Total & 413 & $100 \%$ \\
\hline
\end{tabular}

Fonte: TETO BRASIL (2017)

Para Olga Benário, as respostas sobre esgotamento sanitário também foram variadas. Mais da metade dos entrevistados alegou fazer o despejo no córrego próximo ao assentamento, totalizando $53 \%$, e outros $27 \%$ disseram fazer uso de fossa; $8 \%$ dos domicílios estavam ligados na rede de esgoto pública existente, enquanto 3\% afirmaram despejar seus resíduos no solo. Dos domicílios levantados, $2 \%$ não tinham banheiro em suas casas, $2 \%$ resolviam o esgotamento de outras maneiras e $6 \%$ dos moradores não souberam ou não quiseram responder.

Tabela 42: Olga Benário - Esgotamento sanitário

\begin{tabular}{lcc}
\hline Esgotamento sanitário & NA & $\%$ \\
\hline Rede pública de esgoto & 35 & $8 \%$ \\
Rio, lago ou mar & 217 & $53 \%$ \\
Despejo no solo & 12 & $3 \%$ \\
Fossa (séptica ou não) & 98 & $24 \%$ \\
Não possui banheiro & 9 & $2 \%$ \\
Outros & 15 & $4 \%$ \\
NS/NR & 27 & $6 \%$ \\
Total & 413 & $100 \%$ \\
\hline
\end{tabular}

Fonte: TETO BRASIL (2017) 
Quanto ao descarte de resíduos sólidos, 95\% da comunidade afirmou levar para um ponto de coleta específico, enquanto só $3 \%$ alegaram ter seus lixos coletados em frente de suas casas. Alguns moradores disseram jogar no córrego e em terrenos baldios próximos, totalizando apenas 1\% das respostas.

Tabela 43: Olga Benário - Descarte de lixo

\begin{tabular}{lcc}
\hline Descarte de lixo & NA & $\%$ \\
\hline É coletado em frente de casa & 12 & $3 \%$ \\
Leva para um ponto de coleta & 393 & $95 \%$ \\
Joga na rua/terreno baldio & 4 & $1 \%$ \\
Joga no rio/córrego & 3 & $1 \%$ \\
Queima & 1 & $0 \%$ \\
NS/NR & 0 & $0 \%$ \\
Total & 413 & $100 \%$ \\
\hline
\end{tabular}

Fonte: TETO BRASIL (2017)

Semelhante ao visto nos demais estudos de caso, em Olga Benário a porcentagem de crianças até 4 anos teve destaque com porcentagem maior de crianças até 4 anos, com um total de 15\% da população. As outras duas faixas etárias com maior relevância foi a de 20 a 24 e a de 25 a 29 anos, a primeira com $11 \%$ e a segunda com $12 \%$. A faixa de 30 a 34 anos também ficou próxima desse número com $10 \%$.

Gráfico 19: Olga Benário - Pirâmide etária

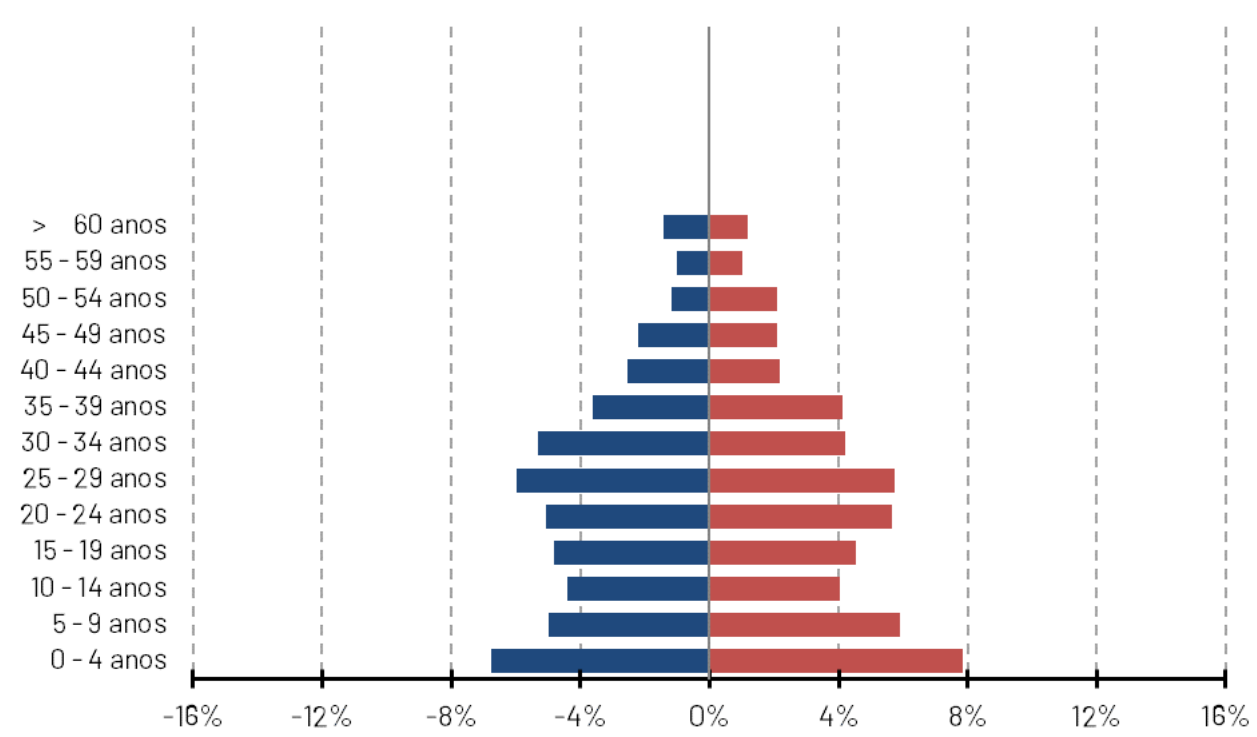


Quando olhamos para a procedência da população de Olga Benário, 50\% nasceu no estado de São Paulo, enquanto 29\% na Bahia. Quando somadas, as pessoas nascidas em estados nordestinos chegaram a totalizar $44 \%$ das respostas.

Gráfico 20: Olga Benário - Procedência dos moradores por unidade de federação

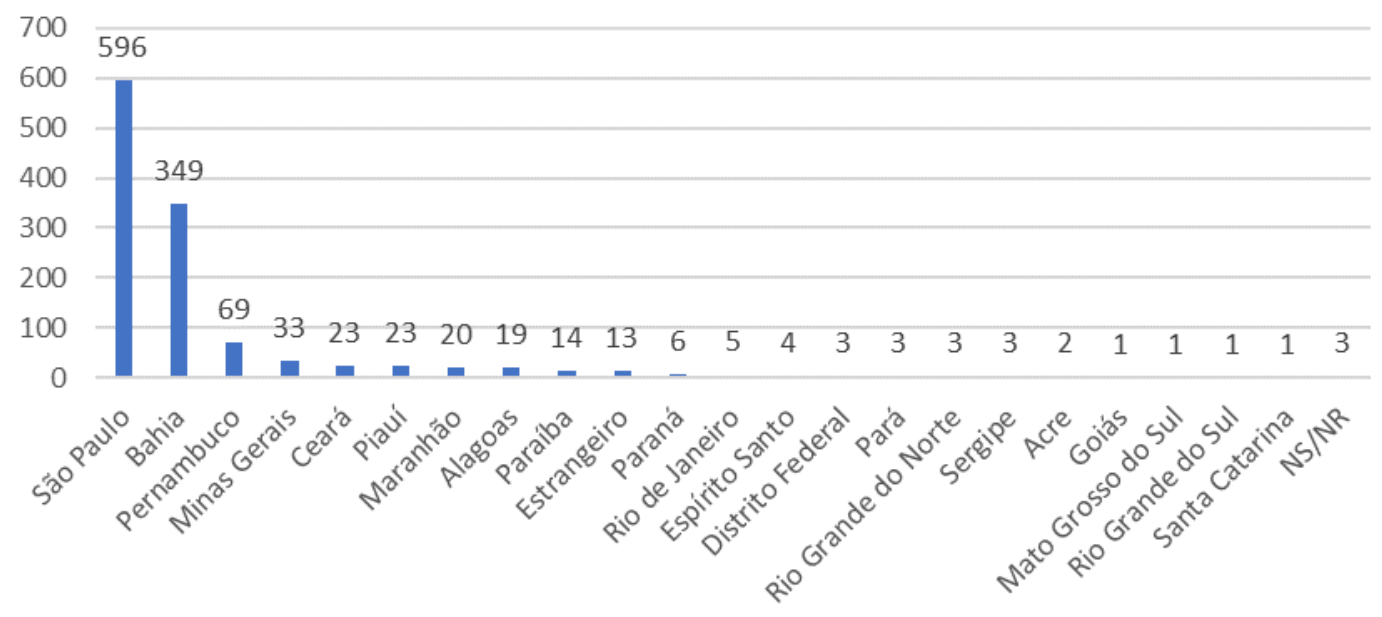

Fonte: Elaborado pela autora a partir de dados do TETO Brasil(2017)

Quando indagados sobre a cor ou etnia com a qual se identificavam, mais da metade da população, com 56\%, se declarou de cor parda, seguida de $21 \%$ de cor branca e $19 \%$ de cor de preta. Pretos e pardos, somados, totalizaram $75 \%$ da população.

Tabela 44: Olga Benário - Autodeclaração de cor/etnia

\begin{tabular}{lcc}
\hline Cor/etnia & NA & $\%$ \\
\hline Preta & 226 & $19 \%$ \\
Branca & 255 & $21 \%$ \\
Parda & 671 & $56 \%$ \\
Amarela (oriental) & 12 & $1 \%$ \\
Indigena & 27 & $2 \%$ \\
NS/NR & 4 & $0 \%$ \\
Total & 1195 & $100 \%$ \\
\hline
\end{tabular}

Fonte: TETO BRASIL (2017) 


\subsection{Considerações sobre os estudos de caso}

Os estudos de caso foram selecionados com o objetivo de elaborar, com maior precisão, uma caracterização das favelas recentes localizadas na metrópole de São Paulo. Para tanto, a escolha dos assentamentos foi feita buscando favelas diferentes no tamanho, na localização e na forma de ocupação. Foram abordadas características referentes à relação com o entorno, habitat e habitabilidade, e foi realizado um breve perfil populacional para cada estudo de caso.

Dessa forma, foi possível comparar tais características, consolidando uma análise mais detalhada. $\mathrm{O}$ resumo das informações está nos quadros a seguir.

Quadro 1: Estudos de caso - aspectos gerais

\begin{tabular}{|c|c|c|c|c|}
\hline & Fazendinha & Luiz Rubino & Pernilongo & Olga Benário \\
\hline Municipio & Osasco & São Paulo & São Paulo & São Paulo \\
\hline $\begin{array}{l}\text { Localização na } \\
\text { metrópole }\end{array}$ & Oeste & Leste & Norte & Sul \\
\hline Ano de surgimento & 2005 & 2007 & 2014 & 2014 \\
\hline Ano de expansão & 2013 & - & 2014 & 2014 \\
\hline Zoneamento & ZEIS & ZEIS & ZEIS & ZEIS \\
\hline $\begin{array}{l}\text { Presença de } \\
\text { córrego }\end{array}$ & $\operatorname{Sim}$ & Sim & Não & Sim \\
\hline $\begin{array}{l}\text { Presença de torre } \\
\text { de alta tensão }\end{array}$ & Sim & Não & Não & Não \\
\hline $\begin{array}{l}\text { Forma de } \\
\text { ocupação }\end{array}$ & Espontânea & Espontânea & Coletiva & Coletiva \\
\hline $\begin{array}{l}\text { Administração dos } \\
\text { lotes }\end{array}$ & Moradores & Moradores & Dirigentes & Dirigentes \\
\hline Venda de lotes & Sim & Sim & Não & Não \\
\hline $\begin{array}{l}\text { Tamanho do } \\
\text { terreno (ha) }\end{array}$ & 3,4 & 10,5 & 0,4 & 3,9 \\
\hline $\begin{array}{l}\text { Construções } \\
\text { Mapeadas }\end{array}$ & 751 & 313 & 136 & 646 \\
\hline $\begin{array}{l}\text { Domicilios } \\
\text { entrevistados }\end{array}$ & 340 & 224 & 80 & 413 \\
\hline $\begin{array}{l}\text { População } \\
\text { entrevistada }\end{array}$ & 1092 & 729 & 212 & 1195 \\
\hline $\begin{array}{l}\text { Data do } \\
\text { levantamento }\end{array}$ & Out/2016 & Ago/2017 & Fev/2016 & Mar/2017 \\
\hline
\end{tabular}


Pernilongo e Olga Benário, devido à sua formação por iniciativa de movimentos sociais ${ }^{8}$, têm características iguais como a inexistência da dinâmica de compra e venda de lotes, que são administrados pelos dirigentes do movimento. $\mathrm{O}$ ano de surgimento e expansão também é comum às duas e, sobre esse ponto, já no capítulo anterior, é levantada a hipótese de que o aumento de ocupações em áreas de ZEIS se deu após a aprovação do Plano Diretor em 2014. Portanto, esses estudos de caso reforçam essa suposição.

Já Luiz Rubino e Fazendinha tiveram formações espontâneas e as primeiras casas são anteriores a 2010. No entanto, em Luiz Rubino, o crescimento de novas construções foi lento e gradual ao longo dos anos, enquanto na Fazendinha houve aumento repentino e exponencial a partir de 2013. Em ambas ocorre comercialização informal dos lotes.

Em relação à presença de córregos nas ocupações, cabe ponderar que não há respeito às áreas de preservação permanente (APPs) das margens para os casos da Fazendinha e da Luiz Rubino. Já na Olga Benário, o córrego que se localiza próximo à ocupação tem sua APP ocupada por uma favela formada anteriormente e que não faz parte do assentamento em questão.

Quanto ao número de construções, observa-se que não há relação com o fato de ser espontânea ou de formação coletiva. Tal característica está ligada, principalmente, ao tamanho do terreno e à localização.

Uma característica comum aos quatro estudos de caso é que todas estão inseridas em área de ZEIS.

\footnotetext{
${ }^{8}$ Destaca-se que os movimentos sociais entre as duas favelas eram diferentes e não tinham relação entre si.
} 
Quadro 2: Estudos de caso - habitat e habitabilidade

\begin{tabular}{|c|c|c|c|c|c|}
\hline & & 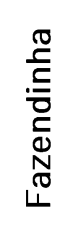 & 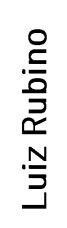 & 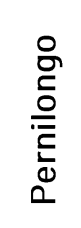 & 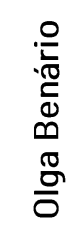 \\
\hline \multirow{2}{*}{ Materialidade das moradias (\%) } & Madeira & 66 & 39 & 98 & 93 \\
\hline & Alvenaria & 28 & 53 & 0 & 2 \\
\hline \multirow{4}{*}{ Esgotamento sanitário (\%) } & Rio/córrego & 76 & 61 & 8 & 53 \\
\hline & Rede pública & 15 & 0 & 40 & 8 \\
\hline & Solo/Fossa & 4 & 30 & 27 & 27 \\
\hline & Sem banheiro & 3 & 7 & 20 & 2 \\
\hline Fornecimento de energia elétrica (\%) & Irregular & 98 & 95 & 98 & 94 \\
\hline Abastecimento de água (\%) & Irregular & 95 & 92 & 89 & 87 \\
\hline Descarte de lixo (\%) & Ponto de coleta & 71 & 95 & 96 & 94 \\
\hline Relação de posse com o terreno(\%) & Próprio & 93 & 90 & 94 & 96 \\
\hline \multicolumn{2}{|c|}{ Densidade mínima do assentamento (hab/ha) } & 321 & 69 & 340 & 306 \\
\hline \multicolumn{2}{|c|}{ Densidade máxima do assentamento (hab/ha) } & 706 & 98 & 530 & 480 \\
\hline \multicolumn{2}{|c|}{ Densidade média do assentamento (hab/ha) } & 513 & 83 & 435 & 393 \\
\hline \multicolumn{2}{|c|}{ Tamanho médio da casa $\left(\mathrm{m}^{2}\right)$} & 26 & 42 & 19 & 36 \\
\hline \multicolumn{2}{|c|}{ Média de cômodos por casa } & 2,1 & 3,0 & 2,0 & 2,9 \\
\hline \multicolumn{2}{|c|}{ Média de pessoas por casa } & 3,2 & 3,3 & 2,7 & 2,9 \\
\hline \multicolumn{2}{|c|}{ Média de dormitórios por casa } & 0,9 & 1,0 & $1,2^{*}$ & 1,0 \\
\hline \multicolumn{2}{|c|}{ Média de camas por pessoa } & 0,8 & 0,9 & 0,8 & 0,9 \\
\hline
\end{tabular}

*Houve divergência na forma de coleta desse dado para esse caso

Fonte: Elaborado pela autora a partir de dados do TETO BRASIL $(2016,2017)$

No que diz respeito à materialidade das moradias, as favelas Pernilongo e Olga Benário tiveram quase que a totalidade feitas com retalhos de madeira. Tal fato tem relação com a presença do movimento social, pois o objetivo dos dirigentes não é o de consolidar a favela, mas o de reivindicar junto ao poder público a construção de habitações de interesse social por meio de programas como o Minha Casa Minha Vida Entidades. Portanto, a orientação que se dá às famílias é de que não construam em alvenaria, pois aquelas moradias devem ser provisórias.

O número de habitações em madeira na Fazendinha apresentou-se menor, mas ainda bastante relevante. Esse aspecto pode ser atribuído ao fato de a maior parte das novas construções serem recentes, principalmente quando 
comparamos com a Luiz Rubino, que teve um número menor de novas construções contabilizadas, sendo mais da metade em alvenaria.

Quanto ao esgotamento sanitário, as respostas foram variadas e refletiram as características geográficas do terreno: para as favelas próximas a córregos, a maior parte das respostas foi de despejo a céu aberto. No caso de Pernilongo, em que o terreno é pequeno e o assentamento de alta densidade, verificou-se que a maior parte das moradias fazem ligação (ainda que irregular) com a rede pública de esgoto. Destaque também para o fato de Pernilongo ter $20 \%$ das moradias sem banheiro próprio.

As respostas sobre o fornecimento de energia elétrica e abastecimento de água foram semelhantes nos quatro estudos de caso. A maior parte está condicionada a instalações irregulares.

Em relação à coleta de lixo, todas, em sua maioria, levam até um ponto específico de coleta. Apenas Fazendinha apresenta uma porcentagem um pouco mais baixa que as demais favelas, pois parte do assentamento é diretamente voltada para ruas asfaltadas e é possível fazer o descarte em frente às casas.

A grande maioria dos moradores das quatro favelas disseram ser donos dos seus terrenos. Isso porque, para favelas recentes, sejam espontâneas ou de ocupação coletiva, não há mercado relevante de locação de imóveis, pois tal população se submete a morar de maneira tão precária justamente pela impossibilidade de pagar um aluguel. Não era raro ouvir relatos de moradores que justificavam ter ido morar nesses locais pois a situação financeira permitia apenas escolher entre pagar pela locação de um imóvel ou se alimentar.

Os números referentes às densidades dos assentamentos estudados não foram muito diferentes, à exceção da Luiz Rubino, que teve um número bastante abaixo das demais. Esse fato é explicado, como já mencionado, pela dificuldade de acesso e pelo longo percurso para chegar nos serviços mais próximos, sendo uma comunidade preterida em relação às outras.

Sobre a questão das densidades, vale destacar que o município de São Paulo tinha densidade média, em 2010, de acordo com o Censo, de 
aproximadamente $74 \mathrm{hab} / \mathrm{ha}$, enquanto Osasco apresentava $103 \mathrm{hab} / \mathrm{ha}$. Ou seja, apenas Luiz Rubino se inseria dentro da média municipal, enquanto as demais eram pelo menos três vezes mais densas que o restante do município.

Os dados referentes ao tamanho médio das moradias e à quantidade de cômodos estão diretamente ligados à densidade. Assentamentos menos densos, como a Luiz Rubino, apresentaram média de casas maiores e mais cômodos, enquanto os mais densos, como a Pernilongo, tiveram, em média, casas menores e com menos cômodos.

A média de dormitórios por casa foi semelhante para todas as favelas, à exceção de Pernilongo, que teve uma média menor devido ao questionário aplicado ter sido diferente, em que se considerou dormitório mesmo casas de um único cômodo. Devido ao tamanho médio das casas em Pernilongo, se a questão tivesse sido feita da mesma maneira que as demais, é bem possível que o número fosse inferior.

Por último, os dados relativos à quantidade de camas foram semelhantes nos quatro assentamentos estudados. Em nenhum caso chegou-se a ter média de uma cama por pessoa. 
Quadro 3: Estudos de caso - perfil da população

\begin{tabular}{|c|c|c|c|c|c|}
\hline & & 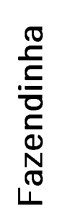 & $\begin{array}{l}\stackrel{ }{\frac{C}{0}} \\
\frac{2}{2} \\
\stackrel{N}{3}\end{array}$ & 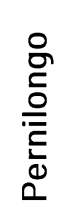 & 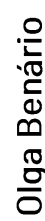 \\
\hline \multirow{7}{*}{ Faixa etária } & $0-4$ anos $(\%)$ & 17 & 13 & 13 & 15 \\
\hline & $5-9$ anos $(\%)$ & 12 & 13 & 10 & 11 \\
\hline & $10-14$ anos $(\%)$ & 10 & 10 & 9 & 9 \\
\hline & $15-19$ anos $(\%)$ & 9 & 8 & 12 & 9 \\
\hline & $20-24$ anos (\%) & 13 & 10 & 12 & 11 \\
\hline & $25-29$ anos $(\%)$ & 12 & 10 & 8 & 12 \\
\hline & $30-35$ anos $(\%)$ & 10 & 8 & 7 & 9 \\
\hline \multirow{3}{*}{ Procedência } & São Paulo (\%) & 71 & 67 & 73 & 50 \\
\hline & Bahia (\%) & 13 & 12 & 8 & 29 \\
\hline & Estados nordestinos(\%) & 25 & 28 & 21 & 44 \\
\hline \multirow{4}{*}{ Cor ou etnia } & Parda (\%) & 51 & 45 & 41 & 56 \\
\hline & Preta $(\%)$ & 21 & 21 & 33 & 19 \\
\hline & Branca $(\%)$ & 26 & 29 & 26 & 21 \\
\hline & Pretos e pardo (\%) & 72 & 66 & 74 & 75 \\
\hline
\end{tabular}

Fonte: Elaborado pela autora a partir de dados do TETO BRASIL $(2016,2017)$

Em todos os casos, a maior porcentagem foi de crianças até 4 anos. No caso da Luiz Rubino, a faixa de 5 a 9 anos também teve uma porcentagem alta. Para as idades adultas, a faixa de 20 a 24 anos foi predominante, à exceção de Olga Benário, que teve uma concentração um pouco maior entre os 25 a 29 anos.

Quanto à procedência, prevaleceram os nascidos no estado de São Paulo, mas com relevância para os nascidos na região Nordeste. A presença de baianos foi um destaque na Olga Benário, com quase 30\% da população.

No geral, a maior parte das pessoas se autodeclararam pardas. Quanto às negras e brancas, os números ficaram equilibrados. Pretos e pardos ficaram na casa dos $70 \%$ em todos os estudos de caso, à exceção da Luiz Rubino, que atingiu uma porcentagem um pouco menor. 
$106 \bullet$ favelas na metrópole de são paulo 


\section{CONSIDERAÇÕES FINAIS}

É extensa a bibliografia que retrata e analisa os processos e características inerentes à produção de assentamentos informais periféricos, pois tal dinâmica se mostrou presente nas principais metrópoles brasileiras nas últimas décadas. No entanto, o que se observou em campo, recentemente, foi o ressurgimento de novos assentamentos precários, inicialmente construídos de madeira para, num momento posterior, serem substituídos por alvenaria. Sobre essas dinâmicas recentes há uma lacuna de informações. As políticas habitacionais - que sequer dão conta da demanda existente - são voltadas para melhorias e urbanização de áreas já consolidadas. Para os novos núcleos de favelas, que são consequência de um déficit que cresce diante de um momento de crise e de empobrecimento das camadas menos favorecidas ou mesmo de um crescimento populacional já previsto, não há políticas públicas direcionadas. São assentamentos de extrema precariedade recém-surgidos pela lógica da necessidade, que concentram, em grande parte, populações abaixo da linha de pobreza e muitas vezes invisíveis aos olhos não só do Estado, mas da sociedade como um todo.

Tendo essa problemática como perspectiva, a pesquisa em questão teve como propósito dar enfoque justamente a esses novos espaços de moradia precária, que se mostram mais vulneráveis do que as favelas mais antigas, mencionadas no capítulo 1 .

Não foram encontradas respostas para todas as questões que surgiram a partir dessa pesquisa. Dessa forma, o caminho percorrido foi o de levantar hipóteses e sugerir possíveis explicações. Por outro lado, algumas descobertas acerca do objeto de estudo podem ser destacadas a partir dos dados levantados.

Com base nas informações apresentadas, concluiu-se que as favelas recentes são assentamentos que surgem, em sua maioria, nas franjas metropolitanas, mas que buscam ocupar terrenos vazios adjacentes ao mínimo de infraestrutura já estabelecida. O destino de preferência é São Paulo, que 
concentra mais oportunidades e acesso mais fácil aos serviços públicos em comparação com a maior parte dos demais municípios.

Os dados apontaram também que a população que procurou esses espaços para morar eram, em sua maioria, casais jovens com filhos pequenos, ou seja, núcleos familiares recém-formados de uma nova geração situada na classe mais baixa da população.

Quanto à forma de surgimento dessas favelas, ficou evidente a ativa atuação dos movimentos sociais, principalmente no município de São Paulo. Em um país em que a propriedade privada está acima do direito à moradia e a prática de ocupar áreas ociosas é cada vez mais criminalizada, faz-se necessário destacar:

\begin{abstract}
A invasão de terras é parte integrante do processo de urbanização no país. Gilberto Freire se refere a ela como prática de 100 anos atrás. A novidade recente, que vem dos anos 80 , é que as invasões começam a se transformar: de ocupações gradativas, resultado de ações individuais familiares, para ganhar um sentido massivo e organizado, a partir da crise econômica que se inicia em 1979. Várias cidades brasileiras apresentam, a partir dessa data, a ocorrência de ocupações coletivas e organizadas de terra, mais raras nas décadas anteriores. Isto não significa que as ocupações gradativas $\mathrm{e}$ espontâneas deixaram de existir. Ao contrário, continuaram a se fazer e a constituir a maior causa da origem da formação de favelas, mas o fato é que passaram, a partir dessa data, a conviver com a prática citada. (MARICATO, 1999)
\end{abstract}

Essa afirmação pode ser comprovada a partir dos dados apresentados pois, embora as ocupações coletivas tenham tido destaque no ano de 2014, ao observar o conjunto total de informações, o número de novos núcleos surgidos espontaneamente foi maior.

Foram identificadas duas razóes que podem estar relacionadas ao alto crescimento de novas construções posteriores a 2013. Entre elas, estão o processo de revisão do Plano Diretor de São Paulo entre os anos de 2013 e 2014 e a crise econômica visivelmente sentida a partir de 2015. O impacto na economia teve como consequência aumento considerável das taxas de desemprego, em que os postos de trabalho mais afetados foram aqueles ocupados pelas classes mais baixas: o trabalho doméstico, a construção civil e a indústria. 
Outro tema de destaque dessa pesquisa foi o protagonismo das ZEIS junto às favelas recentes no período estudado. Seja por iniciativa coletiva ou espontânea, os assentamentos mapeados estavam, em sua maioria, concentrados nessas zonas. O que vale reiterar sobre esse ponto é que, ainda que esse instrumento urbanístico resguarde a população vulnerável de uma possível remoção, apenas a demarcação de terras no zoneamento municipal é insuficiente como política habitacional.

Tanto na análise dos dados regionais do terceiro capítulo quanto nos estudos de caso, ficou claro que as moradias construídas nesse tipo de favela são muito precárias. A alvenaria tem relevância como materialidade das construções, mas ainda prevalecem os retalhos de madeira como principal alternativa para as famílias que vivem nessas condições. A alta densidade desses assentamentos, em conjunto com a ausência de recuos e o diminuto tamanho das moradias, contribuem para a conformação de um espaço extremamente insalubre.

Ou seja, ainda que o aumento de ZEIS no novo zoneamento da cidade seja um avanço significativo, a delimitação de polígonos na malha urbana sem uma política habitacional consistente e específica para a demanda da população mais vulnerável não fará diminuir a precariedade habitacional na qual ela vive.

Por outro lado, também é importante ponderar que o déficit habitacional é um tema tão complexo que dificilmente se resolverá com políticas pontuais na escala municipal. Para além dessa pesquisa, a problemática se estende para todo o sul global e está inserida dentre uma das consequências do sistema capitalista desigual no qual vivemos.

De todo modo, o trabalho aqui apresentado, desde o início, tinha o propósito principal de trazer à tona e dar visibilidade ao surgimento e à presença constantes desse tipo de assentamento nos territórios urbanos. A tentativa foi de apresentar a problemática, descrevendo suas principais características e dinâmicas, tendo ciência de que ainda há muito a ser explorado sobre o tema.

A pesquisa se encerra com a certeza de que há uma necessidade real de se olhar para a questão referente às favelas recentes dentro da política 
habitacional com o objetivo de, no mínimo, mitigar as condições precárias em que essa população vive. 


\section{REFERÊNCIAS BIBLIOGRÁFICAS}

ABRAMO, P. Favela e mercado informal: a nova porta de entrada dos pobres nas cidades brasileiras. Porto Alegre: ANTAC, 2009.

ABREU, Mauricio de Almeida. Reconstruindo uma história esquecida: origem e expansão inicial das favelas do Rio de Janeiro. In: Escritos sobre espaço e história / organização Fania Fridman, Rogério Haesbaert. - 1. ed. Rio de Janeiro: Garamond, 2014, p. 421-450.

BONDUKI, Nabil. Origens da habitação social no Brasil: arquitetura moderna, lei do inquilinato e difusão da casa própria. 5. ed. São Paulo: Estação Liberdade, 2011.

CARDOSO, A. L. Avanços e desafios na experiência brasileira de urbanização de favelas. In: Encontro Nacional de Pós-graduação e Pesquisa em Planejamento Urbano e Regional, 12., 2007, Belém. Anais.... Belém, 2007.

IBGE. Censo Demográfico 2010. Aglomerados subnormais: primeiros resultados. Rio de Janeiro: IBGE, 2011.

IBGE. Censo Demográfico 2010. Aglomerados subnormais: informações territoriais. Rio de Janeiro: IBGE, 2013.

GOVERNO DO ESTADO DE SÃO PAULO. Sistema de Informações Metropolitanas - Emplasa. Disponível em: < http://www.sim.emplasa.sp.gov.br/>

MARICATO, E. A terra é um nó na sociedade brasileira... também nas cidades. Cultura Vozes, Petrópolis - Ed. Vozes, v. 93, n.6, p.7-22, 1999.

MAUTNER, Y. M. M. A periferia como fronteira da expansão do capital. In: DEAK, C; SCHIFFER, S. (orgs.). O processo de urbanização no Brasil. Edusp/Fupam, 1999. 
MENEZES, Francisco; JANNUZZI, Paulo. Com o aumento da extrema pobreza, Brasil retrocede dez anos em dois. Teoria e Debate, 2018. Disponível em: $<$ https://teoriaedebate.org.br/2018/03/07/com-o-aumento-da-extrema-pobrezabrasil-retrocede-dez-anos-em-dois/>

PASTERNAK, Suzana. Desenhando os espaços de pobreza. Cadernos de pesquisa do LAP, São Paulo, n. 39, 2004.

PASTERNAK, S. São Paulo e suas favelas. Revista Pós, FAUUSP, 2006.

PASTERNAK, Suzana; D'OTTAVIANO, Camila. Favelas no Brasil e em São Paulo: avanços nas análises a partir da Leitura Territorial do Censo de 2010*. Cad Metrop. 2016, vol.18, n.35.

POCHMANN, MARCIO. Política de ajuste econômico e desemprego no Brasil metropolitano nos últimos 35 anos. In: Júnior Macambira, Tarcisio Patricio Araújo, Roberto Alves de Lima. (Org.). Mercado de Trabalho. Qualificação, Emprego e Políticas Sociais. 1ed.Fortaleza: Instituto de desenvolvimento do Trabalho-Núcleo de Economia Solidária da Universidade Federal de PE, 2016, v. , p. 11-26.

TETO BRASIL. Escutando Comunidades 2016. Levantamento de informações em Pernilongo e Fazendinha.

TETO BRASIL. Escutando Comunidades 2017. Levantamento de informações em Olga Benário e Luiz Rubino.

TETO BRASIL. Mutirão de Visitas 2014. Levantamento de informações de assentamentos precários. Municípios: Arujá, Barueri, Carapicuíba, Embu das Artes, Guarulhos, Itapecerica da Serra, Osasco, São Paulo, Taboão da Serra. São Paulo, 2014. 
TETO BRASIL. Mutirão de Visitas 2015. Levantamento de informações de assentamentos precários. Municípios: Arujá, Barueri, Caieiras, Diadema, Ferraz de Vasconcelos, Itaquaquecetuba, Mauá, São Bernardo do Campo, São Paulo, Santo André e Suzano. São Paulo, 2015.

TETO BRASIL. Mutirão de Visitas 2016. Levantamento de informações de assentamentos precários. Municípios: Barueri, Carapicuíba, Embu das Artes, Osasco, Taboão da Serra e São Paulo. São Paulo, 2016.

TETO BRASIL. Mutirão de Visitas 2017. Levantamento de informações de assentamentos precários. Municípios: São Paulo, Mairiporã, Osasco, Barueri, Jandira, Carapicuíba, Embu das Artes, Itapecerica da Serra e Cotia. São Paulo, 2017.

VALLADARES, Licia do Prado. A invenção da favela: do mito de origem a favela.com. Rio de Janeiro: FGV, 2005.

\section{Legislação consultada}

EMBU DAS ARTES. Lei nº 726/78. Embu das Artes, 1978.

JANDIRA. Lei No 1603/06. Jandira, 2006.

ITAPECERICA DA SERRA. Lei Complementar no 26/12. Itapecerica da Serra, 2012.

ITAQUAQUECETUBA. Lei Complementar no 178/09. Itaquaquecetuba, 2009.

MAUÁ. Lei No 4153/07. Mauá, 2007.

OSASCO. Lei No 1485/78. Osasco, 1978.

SÃO BERNARDO DO CAMPO. Lei No 6222/12. São Bernardo do Campo, 2012.

SÃO PAULO (município). Lei no 16.050/14. São Paulo, 2014.

SUZANO. Lei no 277/15. Suzano, 2015.

TABOÃO DA SERRA. Lei no 132/06. Taboão da Serra, 2006. 
$114 \bullet$ favelas na metrópole de são paulo 
ANEXOS 



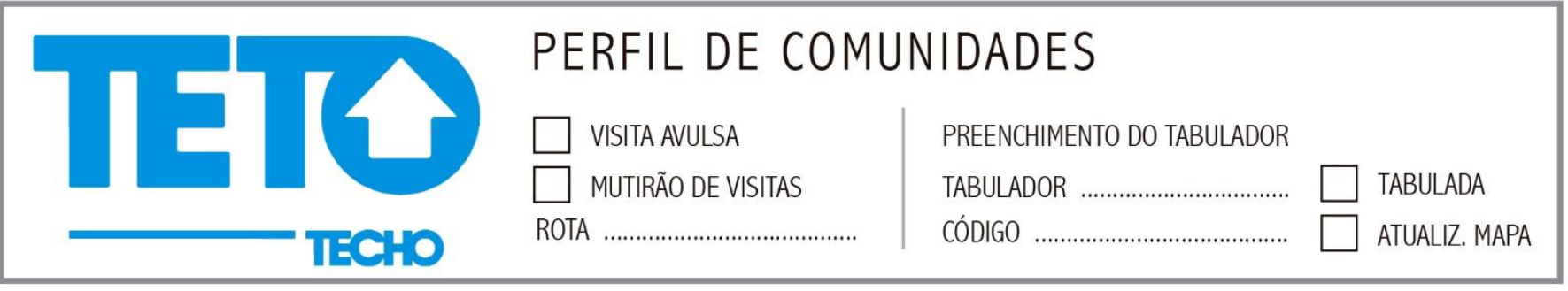

\section{DADOS DO VOLUNTÁRIO}

NOME

EMAIL

\section{DADOS DA COMUNIDADE}

- DATA

$\ldots$

......................

ESTADO

MUNICÍPIO

ZONA

SUBPREFEITURA

ENDEREÇO (anotar todas as ruas que cercam a comunidade)

NOME DA COMUNIDADE NA ROTA

NOME DA COMUNIDADE

\section{DADOS DO ENTREVISTADO 1}

NOME

TELEFONE

RELAÇÃO COM A COMUNIDADE

$\square$ morador

$\square$ represente comunitário

$\square$ outro

A FONTE E CONFIÁVEL

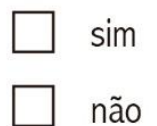

OUTRAS INFORMAÇÕES
TELEFONE

LÍDER

\section{TAMANHO}

Total de famílias

Total de barracos

TIPO DE ASSENTAMENTO

$\square$ Favela urbana

$\square$ Assentamento Rural

$\square$ Quilombola

$\square$ Indígena

EDIFICAÇÕES

$\square$ Maioria barracos

$\square$ Maioria Alvenaria

\section{DADOS DO ENTREVISTADO 2}

$>$ NOME

TELEFONE

RELAÇÃO COM A COMUNIDADE

$\square \quad$ morador
$\square \quad$ representante comunitário
$\square \quad$ outro

A FONTE E CONFIÁVEL

$\square \operatorname{sim}$

$\square$ não

OUTRAS INFORMAÇÕES 


\section{HISTÓRIA DO ASSENTAMENTO}

- HÁ QUANTOS ANOS EXISTE A COMUNIDADE ?

QUAL FOI O ANO OU O PERÍODO DE MAIOR CRESCIMENTO DA COMUNIDADE ?

QUANDO FOI CONSTRUIIDA A ÚLTIMA CASA NA COMUNIDADE?

COMO A COMUNIDADE FOI FORMADA E COMO FOI A OCUPAÇÃO? (resposta única)

$\square$ Ocupação das terras de forma progressiva e desorganizada

$\square \quad$ Não sabe / não respondeu

$\square$ Ocupação das terras de forma coletiva e organizada (com

$\square$ Outro, especificar:

posterior regularização das terras)

$\square$ De maneira planejada com a participação do Governo

(propriedade pública)

QUAL É O MATERIAL PREDOMINANTE DAS RUAS? (Resposta única)

$\square$ Terra $\square$ Pedra $\square$ Asfalto $\square$ Outro:

\section{COM RELAÇÃO AO TERRENO, QUAL DESTAS SITUAÇÕES É PREDOMINANTE NO ASSENTAMENTO?}

$\square$ Os moradores têm um título de propriedade

$\square$ Os moradores têm acordos de contrato de compra, mas eles não têm nenhum título
Os moradores não têm nem título de propriedade, nem acordos de contrato de compra

Não sabe / Não respondeu

COM RELAÇÃO À PROPRIEDADE, O TERRENO É:

$\square$ Privado / particular (Dono:

...) $\square$ Não sabe / Não respondeu

$\square$ Público (Dono:

...) $\square$ Outro:

EXISTE ALGUM PROCESSO DE REINTEGRAÇÃO DE POSSE TRAMITANDO NA JUSTIÇA?

Não

Sim, número de processo :

Outras observações:

\section{CONFIGURAÇÃO DA COMUNIDADE}

- HÁ COMPRA E VENDA DE TERRENOS DENTRO DO ASSENTAMENTO?

$\square \operatorname{Sim} \quad \square$ Não $\quad \square$ Não sabe / não responde

QUEM SÃO OS VENDEDORES ?

$\square$ Tendo deixado a comunidade, os moradores vendem o terreno em que eles estavam morando

Há uma pessoa que vende ou aluga os terrenos

Outro:

Outras observações: 


\section{MATERIAL DAS CASAS}

- QUAL É O MATERIAL PRINCIPAL DA MAIORIA DOS TELHADOS DAS CASAS ?
$\square$ Zinco
Plástico
Não sabe / não respondeu
$\square$ Fibrocimento
Material reciclado
Outro :

QUAL É O MATERIAL PRINCIPAL DA MAIORIA DOS PISOS DAS CASAS ?
$\square$ Terra
$\square$ Madeira
Não sabe / não respondeu
$\square$ Cerâmica
Cimento
Outro:

QUAL É O MATERIAL PRINCIPAL DA MAIORIA DAS PAREDES DAS CASAS?
$\square$ Adobe
Alvenaria
Não sabe / não respondeu
Madeira
Material reciclado
Outro :

Outras observações:

\section{SANEAMENTO E SERVIÇOS BÁSICOS}

- COM RELAÇÃO À ENERGIA ELÉTRICA, QUAL É A SITUAÇÃO PREDOMINANTE?
$\square$ Rede pública (relógio de medição individual)
$\square$ Não sabe / não respondeu
$\square$ Rede pública (relógio de medição comunitário)
$\square$ Não tem
$\square$ Instalação irregular (gato)
$\square$ Outro:

- COM RELAÇÃO AO ESGOTO, QUAL É A SITUAÇÃO PREDOMINANTE?
$\square$ Rede pública (paga conta)
Não sabe / não respondeu
$\square$ Fossa (buraco que armazena esgoto)
Outro :
$\square$ Céu aberto (encanamento improvisado / cai no rio)

- COM RELAÇÃO À ABASTECIMENTO DE ÁGUA, QUAL É A SITUAÇÃO PREDOMINANTE?
$\square$ Rede pública
$\square$ Perfuração ou poço artesiano
$\square$ Instalação irregular (gato)
$\square$ Caminhões-pipa
$\square$ Cisterna
Outro:
$\square$ Não sabe / não respondeu

- COM RELAÇÃO AO TIPO DE ENERGIA USADA PARA COZINHAR, QUAL É A OPÇÃO PREDOMINANTE?
$\square$ Gás natural da rede pública
$\square$ Lenha ou carvão
$\square$ Botijão de gás
Não sabe / não respondeu
$\square$ Eletricidade
Outro:

- EXISTE ILUMINAÇÃO PÚBLICA NA RUAS DA COMUNIDADE?

$\square$ Sim, instalada pelo poder público

$\square$ Não existe

$\square$ Sim, instalada pelos moradores

Outro: 
- EXISTE UMA COLETA DE LIXO QUE ATENDE A COMUNIDADE?

Não

$\square$ Dentro da comunidade

Ponto de coleta

Fora da comunidade

COM RELAÇÃO AO LIXO, ESSAS SITUAÇÕES OCORREM NA COMUNIDADE?
$\square$ Joga no rio / córrego
$\square$ Joga na rua / terreno baldio
$\square$ Queima
$\square$ Outro:

\section{AMBIENTE}

- NA REGIÃO DA COMUNIDADE HÁ:

$\begin{array}{lll}\square \text { Floresta } & \square \text { Torre de alta tensão } \\ \square \text { Rio / canal / córrego } & \square \text { Via férrea } \\ \square \text { Declive } & \square \text { Rodovia } \\ \square \text { Lixão } & \square \text { Resíduos industriais }\end{array}$

$\square \quad$ Atividade agrícola

$\square$ Nada

$\square$ Não sabe / não respondeu

$\square$ Outro:

QUAIS DO EVENTOS SEGUINTES ACONTECERAM NOS ÚLTIMOS 12 MESES:

$\begin{array}{lll}\square \text { Deslizamento } & \square \text { Nenhum } \\ \square \text { Incêndios } & \square \text { Não sabe / Não respondeu } \\ \square \text { Enchente } & \square \text { Outro : ............................................ }\end{array}$

ONDE OS SERVIÇOS SEGUINTES ESTÃO COM RELAÇÃO À COMUNIDADE? (0 tempo deve ser calculado em minutos de caminhada)

Nome:

$\begin{array}{cccccc}\begin{array}{c}\text { Dentro da } \\ \text { comunidade }\end{array} & \begin{array}{c}\text { Menos de } \\ 15 \mathrm{~min}\end{array} & \begin{array}{c}\text { Entre 15 } \\ \text { e } 30 \mathrm{~min}\end{array} & \begin{array}{c}\text { Entre 30 } \\ \text { e } 60 \mathrm{~min}\end{array} & \begin{array}{c}\text { Mais de } \\ 60 \mathrm{~min}\end{array} & \begin{array}{c}\text { Não sabe / } \\ \text { não responde }\end{array} \\ \square & \square & \square & \square & \square & \square\end{array}$

A escola primária mais próxima

Nome:

A escola secundária mais próxima

Nome:

0 hospital público mais próximo

Nome:

0 posto de saúde mais próximo

Nome:

0 posto policial mais próximo

A parada de transporte

público mais próxima

A praça ou o parque

mais próximo

0 centro esportivo ou

cultural mais próximo
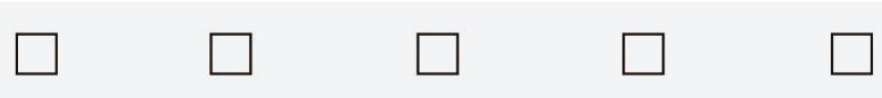

A prefeitura

0 corpo de bombeiros mais próximo

CRAS mais próximo
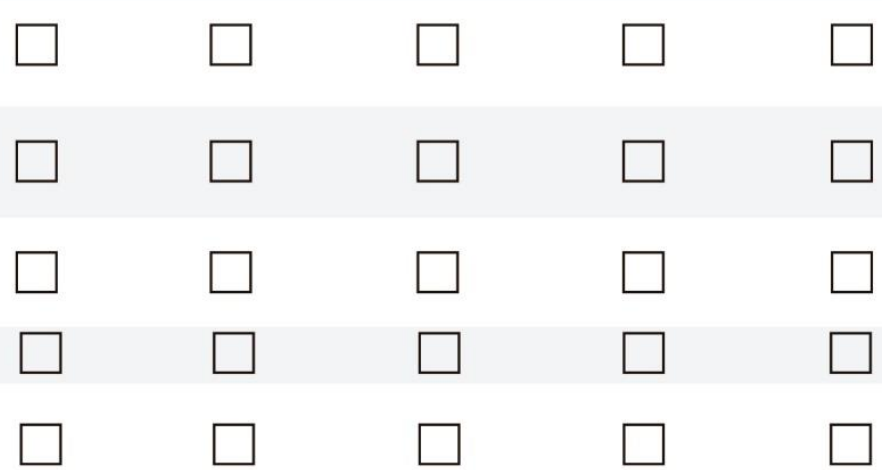


\section{ORGANIZAÇÃO NA COMUNIDADE: EXTERNA}

- EXISTEM ORGANIZAÇÕES DA SOCIEDADE CIVIL QUE DESENVOLVEM UM TRABALHO PERMANENTE NA COMUNIDADE? (ONGS)

$\square$ Sim, existe. Especifique o nome e as atividades

$\square$ Não

$\square$ Não sabe / não respondeu

EXISTEM ORGANIZAÇÕES POLÍTICAS QUE DESENVOLVEM UM TRABALHO PERMANENTE NA COMUNIDADE? (Movimentos sociais)

$\square$ Sim, existe. Especifique o nome e as atividades

$\square$ Não

$\square$ Não sabe / não respondeu

EXISTEM ORGANIZAÇÕES RELIGIOSAS QUE DESENVOLVEM UM TRABALHO PERMANENTE NA COMUNIDADE?

$\square$ Sim, existe. Especifique o nome e as atividades

$\square$ Não

$\square$ Não sabe / não respondeu

\section{ORGANIZAÇÃO NA COMUNIDADE : INTERNA}

QUAL É O NOME DO LÍDER COMUNITÁRIO?

Contato:

EXISTE ALGUM TIPO DE ASSOCIAÇÃO DENTRO DA COMUNIDADE? QUAIS ATIVIDADES REALIZA?

$\square$ Sim, existe. Especifique o nome e as atividades

$\square$ Não

$\square$ Não sabe / não respondeu

COMO FOI FORMADA A ASSOCIAÇÃO?

CNPJ da associação:

$\square$ Motivação dos vizinhos $\square$ Não sabe / não respondeu

$\square$ Apoio de uma organização externa $\square$ Outro:

$\square$ Apoio da prefeitura

QUAIS SÃO OS PROJETOS CRIADOS DESDE A CRIAÇÃO DA ASSOCIAÇÃO?

\begin{tabular}{|c|c|c|}
\hline Infra-estruturas & Formação profissional & Não sabe / não respondeu \\
\hline Cultura & Lazer & 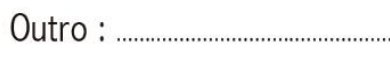 \\
\hline Educação & Saúde & \\
\hline
\end{tabular}

COM QUE FREQUÊNCIA A ASSOCIAÇÃO FAZ REUNIÕES?
$\square$ Semanal
$\square$ Mensal
Não sabe / não respondeu
$\square$ Quinzenal
Outro :

EXISTEM CANAIS DE COMUNICAÇÃO NA COMUNIDADE? (Rádio comunitária, jornal)

$\square \operatorname{Sim}$ (Especifique o canal e o nome).

$\square$ Não

$\square \quad$ Não sabe / não respondeu 


\section{DINÂMICAS E PERPSPECTIVAS DA COMUNIDADE}

- QUAIS SÃO OS TRÊS PROBLEMAS PRINCIPAIS DA COMUNIDADE?

1 -

2 -

$3-$

QUAIS SÃO AS TRÊS CARATERÍSTICAS POSITIVAS DA COMUNIDADE?

1 -

2 -

$3-$

EXISTE ALGUM PROJETO DO GOVERNO EM DESENVOLVIMENTO NA COMUNIDADE? (Programas como CDHU, Minha Casa Minha Vida, Habitação, urbanização, remoção, etc)

$\square \operatorname{Sim}($ Especifique abaixo)

$\square$ Outro (Especifique abaixo)

$\square$ Não

Não sabe / não respondeu

ALGUEM NA COMUNIDADE JÁ RECEBEU ORDEM DE DESPEJO NOS ÚLTIMOS 12 MESES?
$\square$ Não
Sim, de parte de quem?
$\square$ Não sabe / não respondeu
$\square$ do Estado
$\square$ do proprietário do terreno
$\square$ de outro:

HÁ TRÁFICO DE DROGAS NA COMUNIDADE?
$\square$ Não, inexistente
Se sim, seria um impedimento para nosso trabalho?
$\square$ Sim, em alguns locais
$\square$ Sim, presença forte
QUER COMENTAR ALGUMA COISA MAIS COM RELAÇÃO À REALIDADE NA COMUNIDADE?

VOCÊ ACREDITA QUE O TETO DEVA TRABALHAR NA COMUNIDADE? POR QUÊ? OS MORADORES ESTARIAM DISPOSTOS A AJUDAR? (Responder no carro com os voluntários).

\section{OBSERVAÇÕES PARA O VOLUNTÁRIO}

1 - Faça um esboço da comunidade contendo áreas de interesse (córregos, entradas da comunidade, áreas com barracos, áreas com casas de alvenaria, bares conhecidos, pontos de referência, etc)

2 - Registre todos os contatos encontrados durante a visita.

3 - Tire fotos dos pontos de referêcia na comunidade e, se os moradores permitirem, das casas precárias encontradas. 


\section{MAPA}
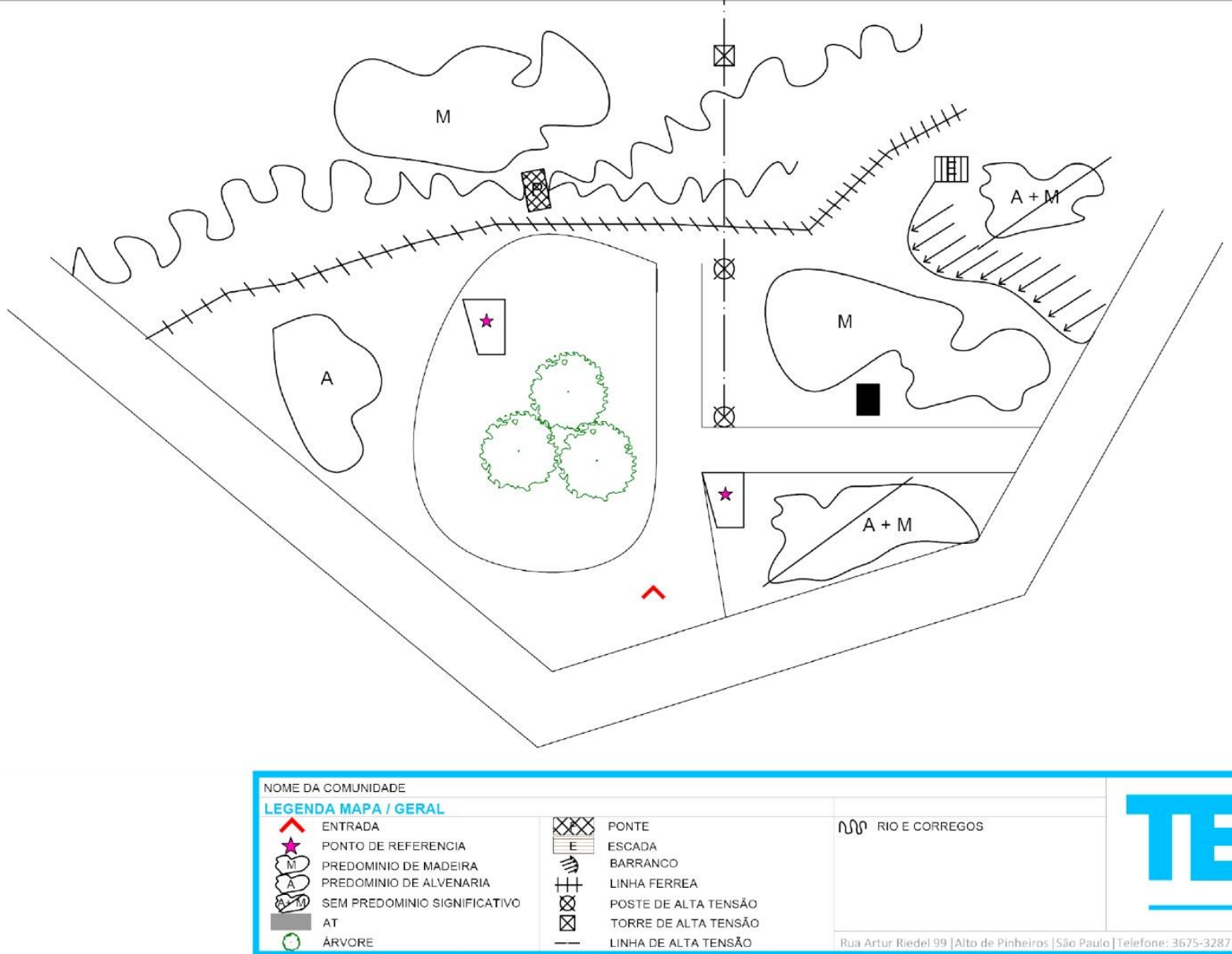

\begin{tabular}{|c|c|}
\hline $\begin{array}{l}X X X \\
E \\
\Rightarrow\end{array}$ & $\begin{array}{l}\text { PONTE } \\
\text { ESCADA } \\
\text { BARRANCO }\end{array}$ \\
\hline & LINHA FERREA \\
\hline$\otimes$ & $\begin{array}{l}\text { POSTE DE ALTA TENSÃO } \\
\text { TORRE DE ALTA TENSÃOO }\end{array}$ \\
\hline
\end{tabular}

NOS RIOE CORREGOS

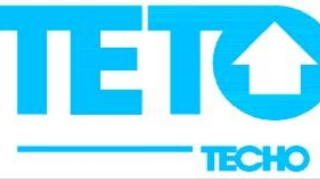

INHA DE ALTA TENSÃO 

FAZENDINHA

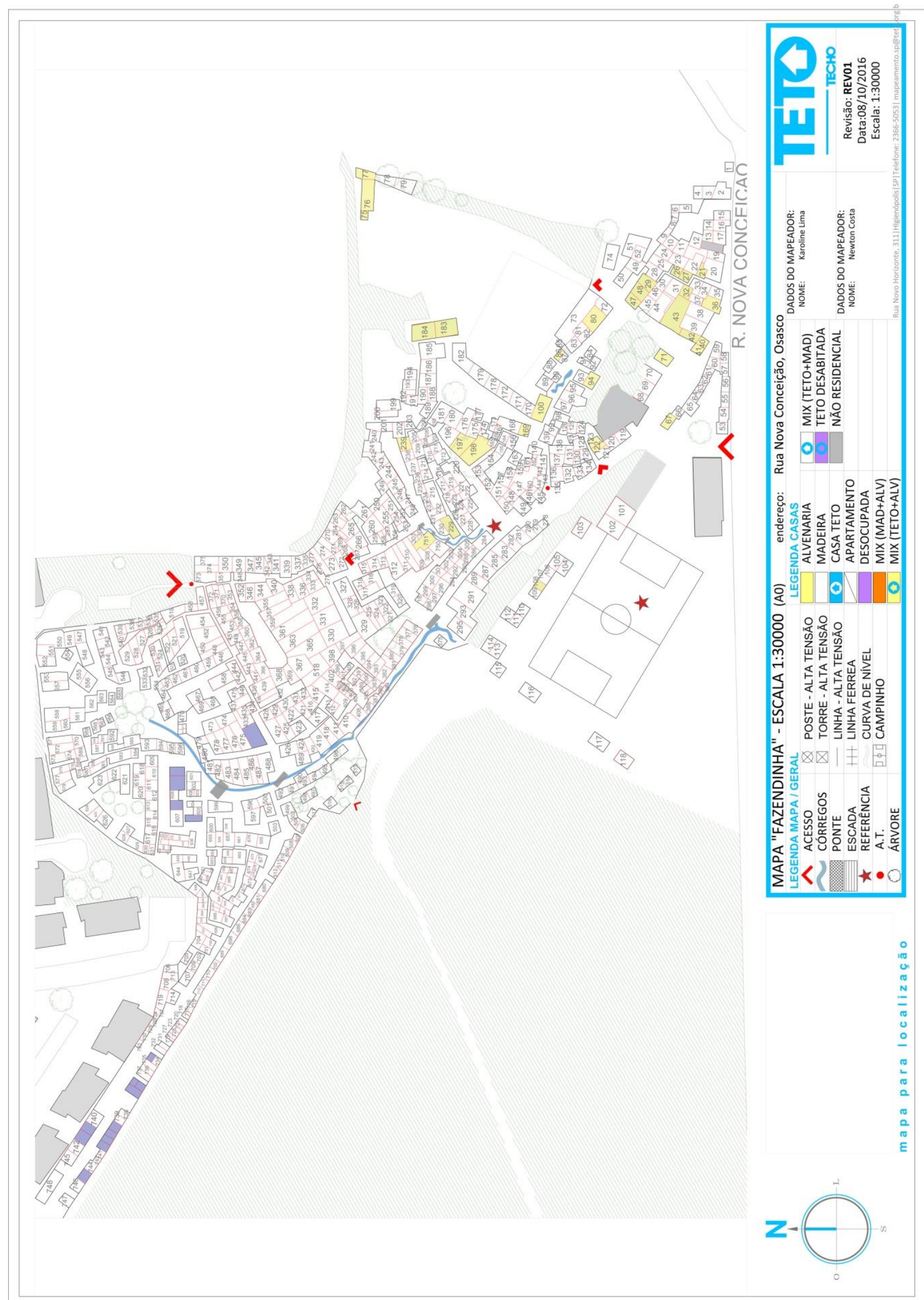




\section{OLGA BENARIO}

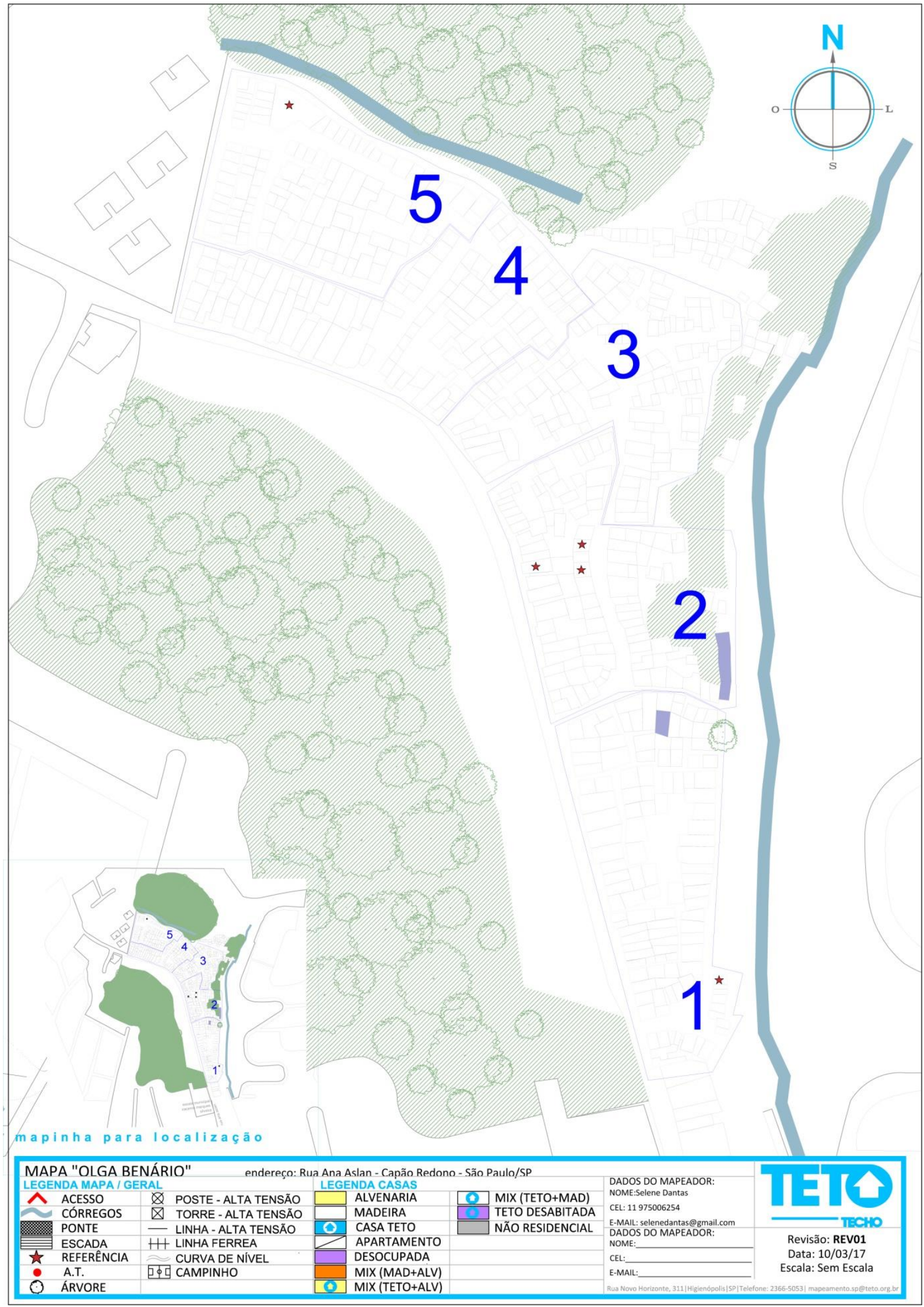




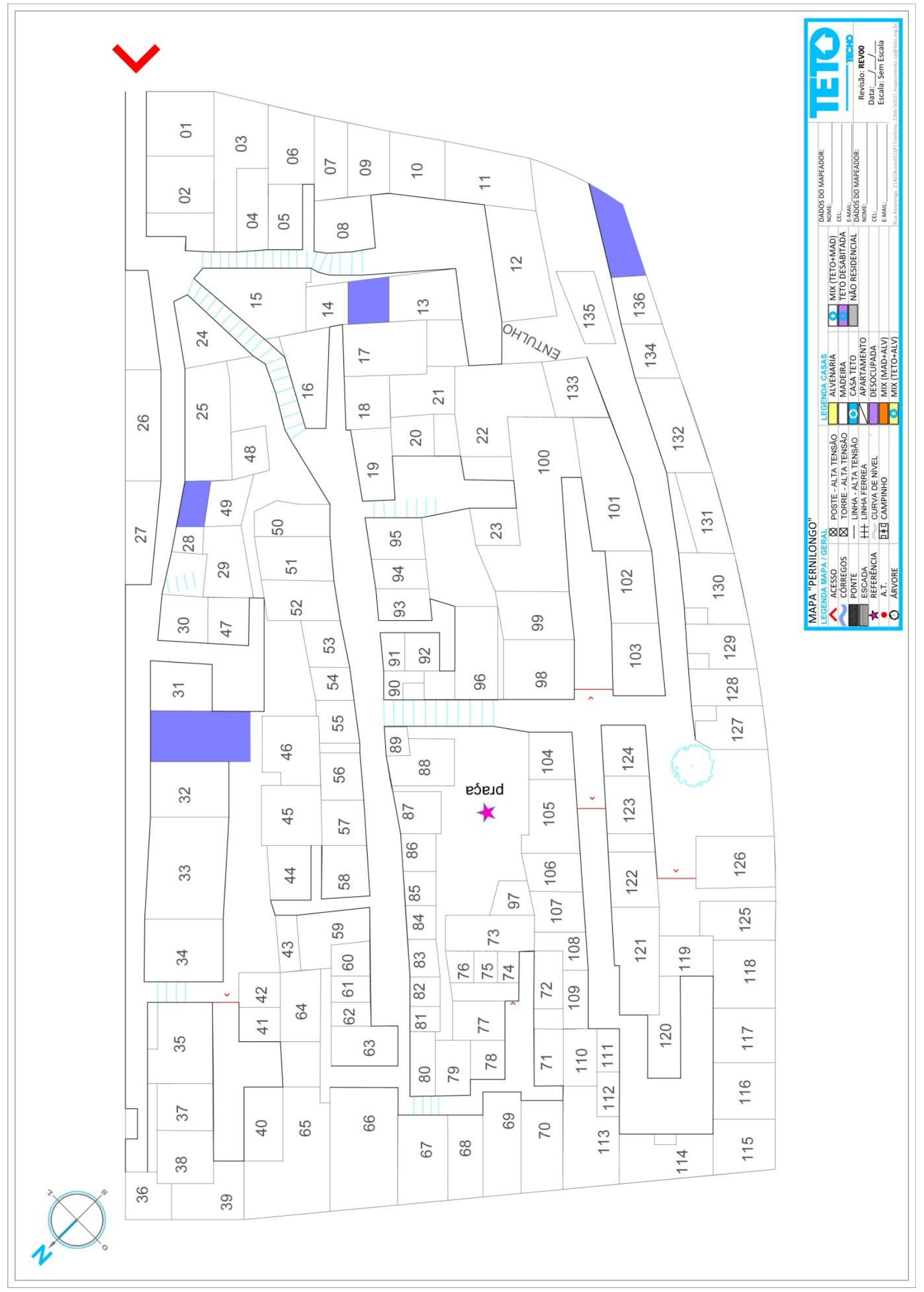




\section{LUIZ RUBINO}

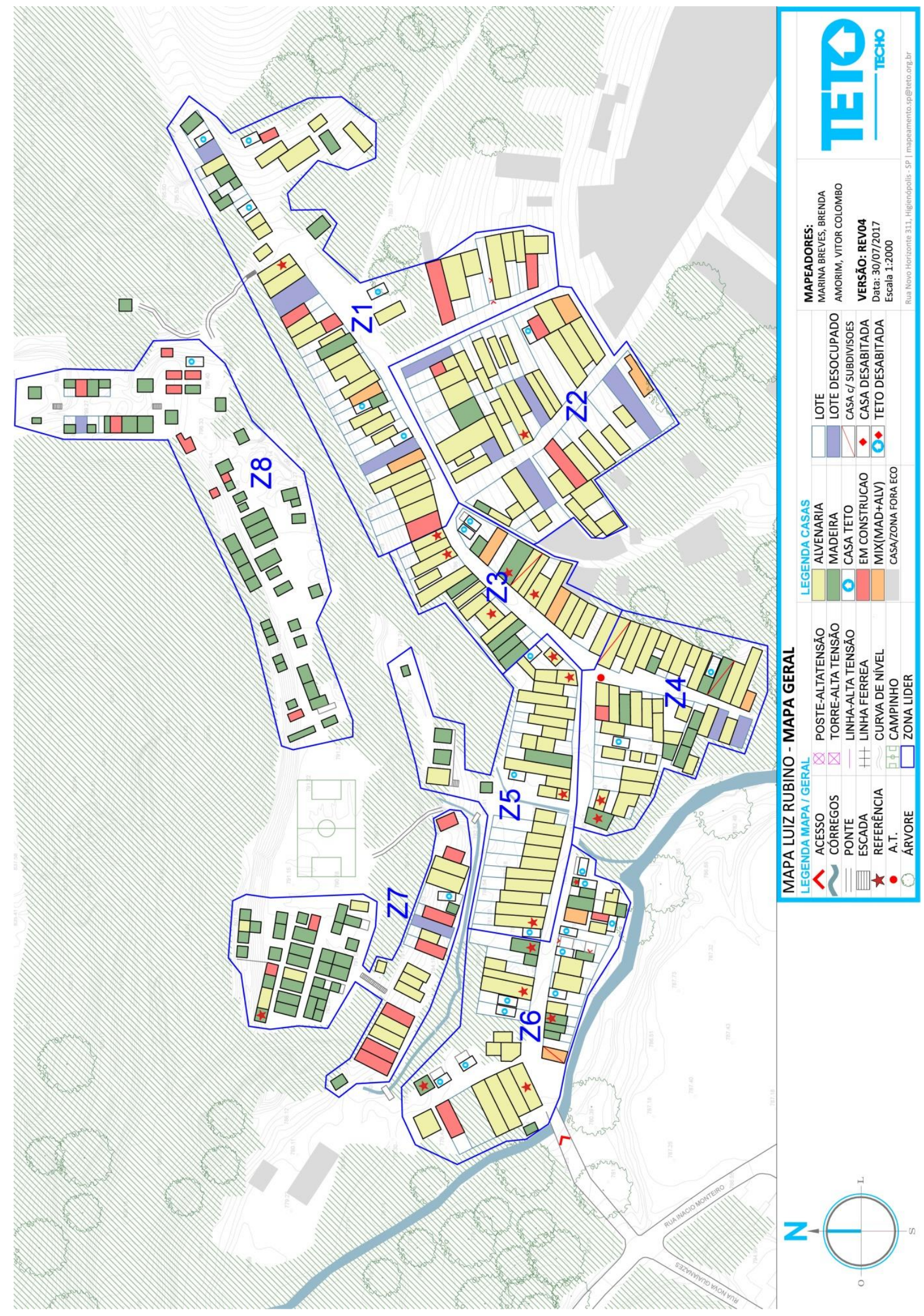




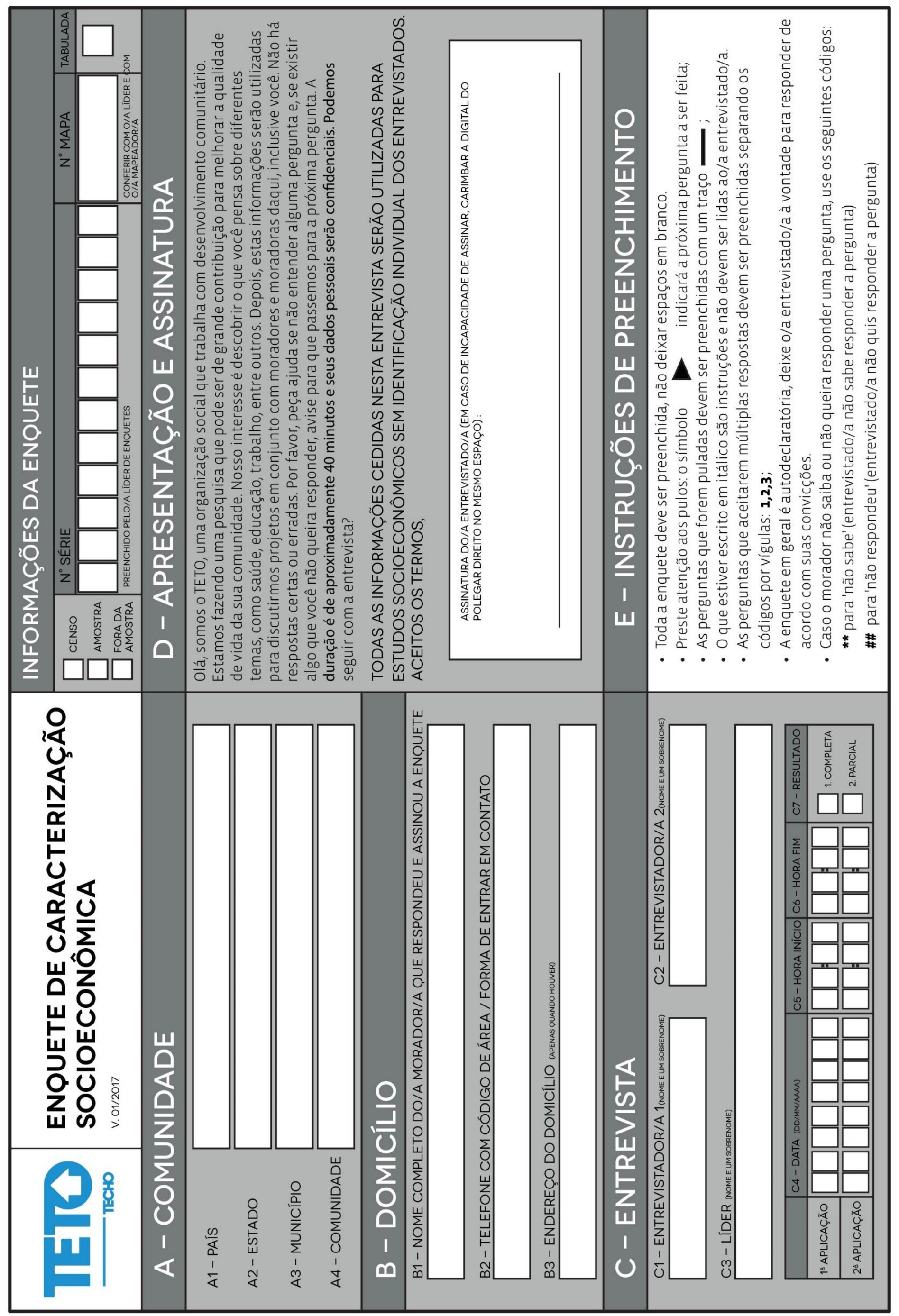




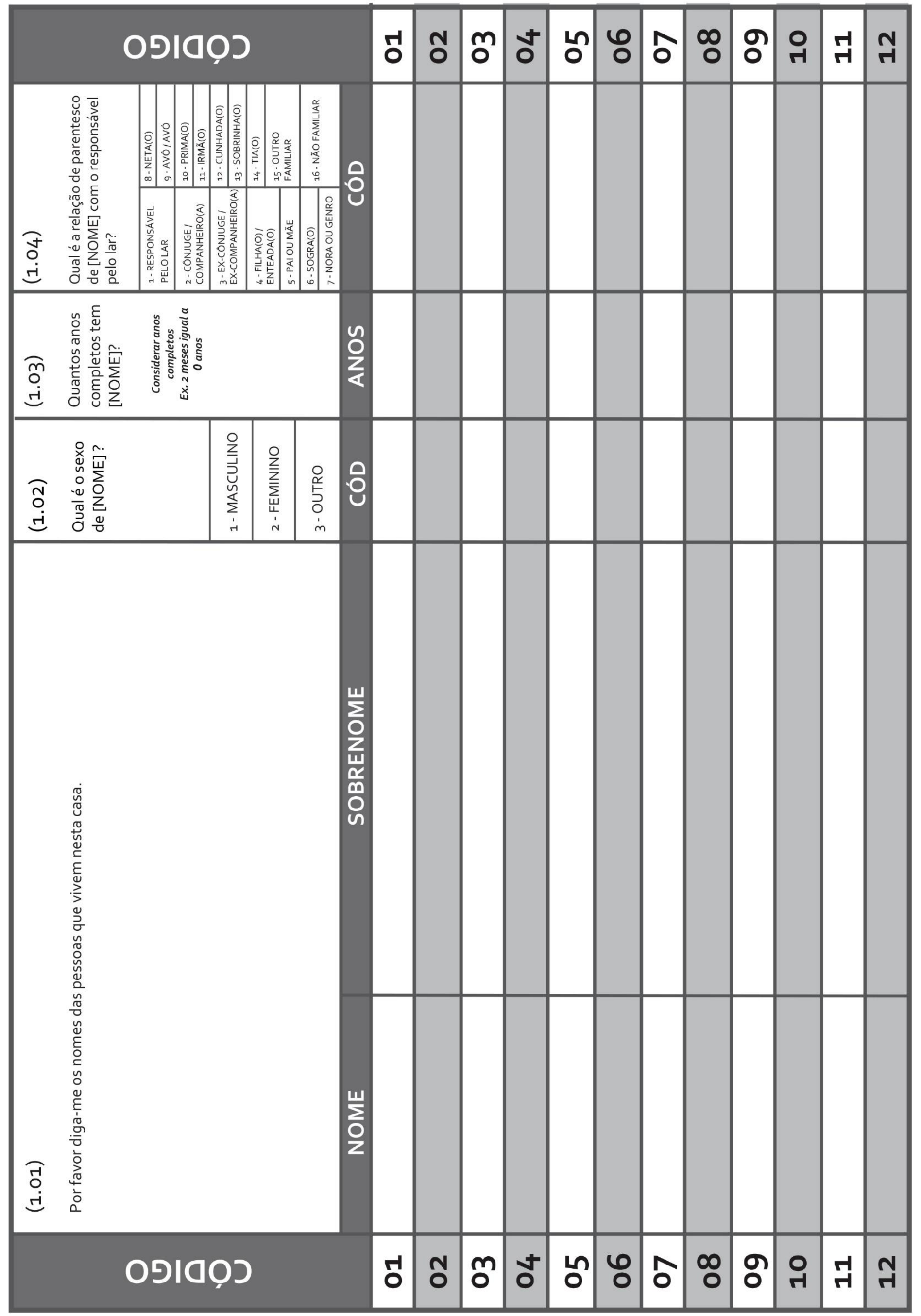




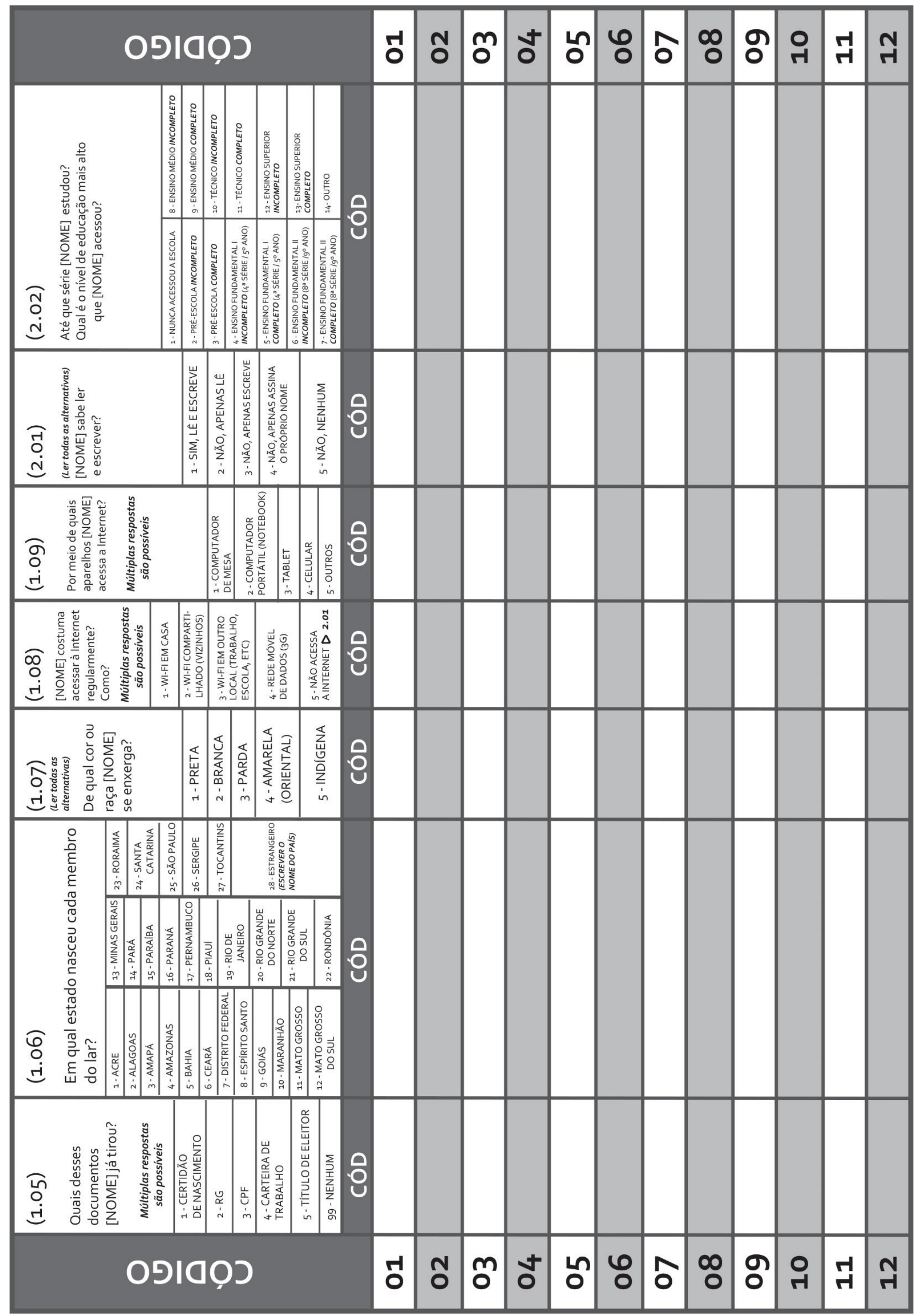




\section{כọופטס}

\section{ก}

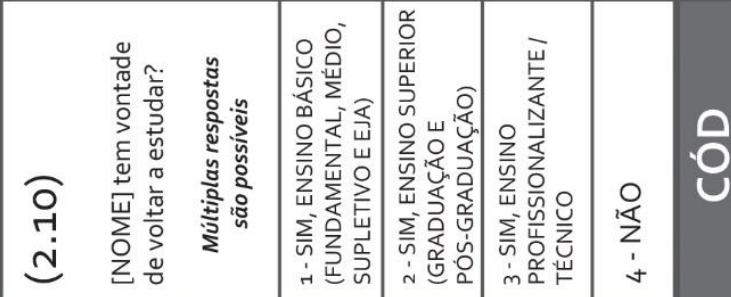

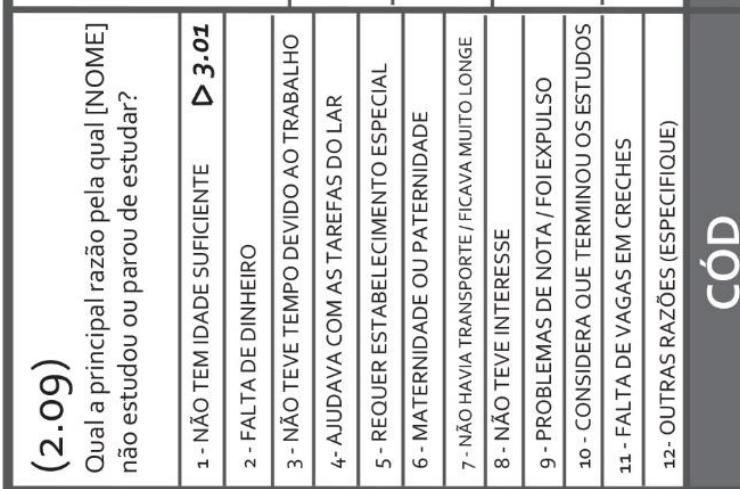

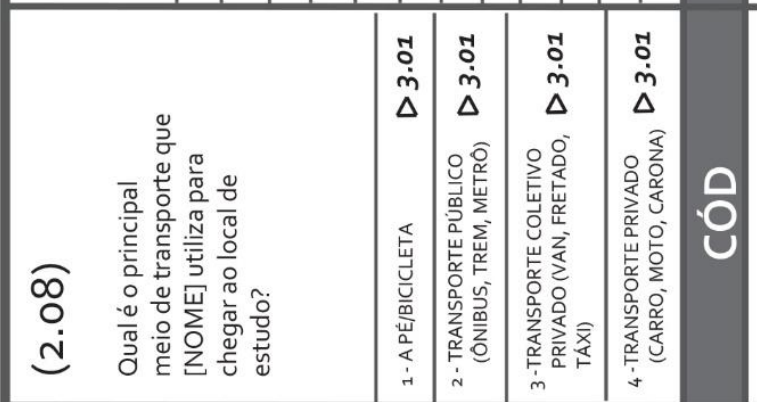

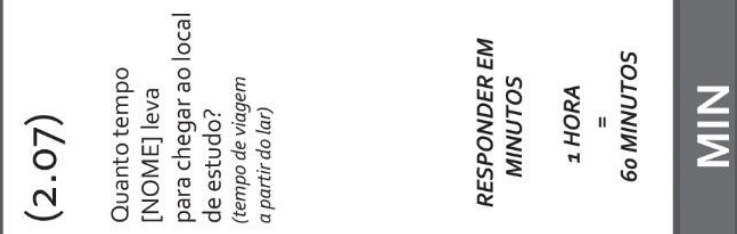

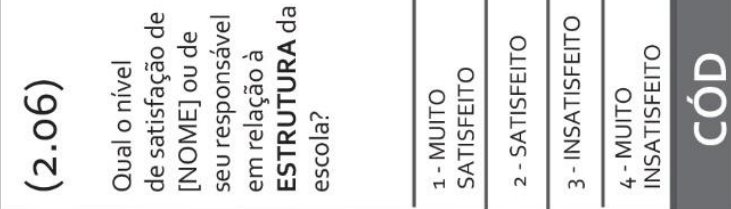

\begin{tabular}{|c|c|c|c|c|c|c|c|c|c|c|c|c|c|c|c|c|c|c|}
\hline 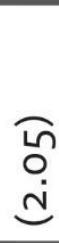 & 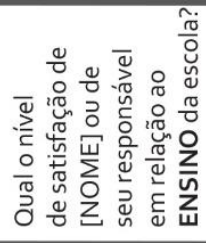 & & 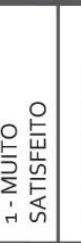 & 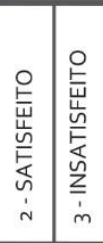 & 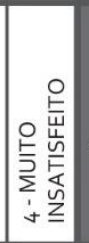 & هُ & & & & & & & & & & & & \\
\hline $\begin{array}{l}\text { ‡ } \\
0 \\
\text { ì }\end{array}$ & 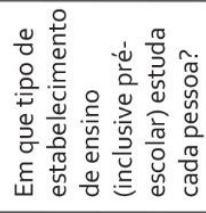 & 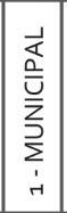 & 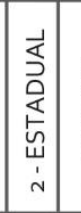 & 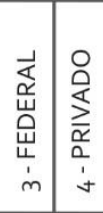 & $\begin{array}{l}\text { O } \\
\text { צ } \\
\text { Oे } \\
\text { in }\end{array}$ & 8 & & & & & & & & & & & & \\
\hline $\begin{array}{l}\text { m̃ } \\
\text { id }\end{array}$ & 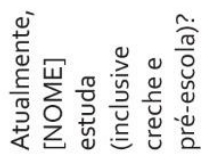 & & & $\begin{array}{l}\sum_{n} \\
1 \\
r\end{array}$ & 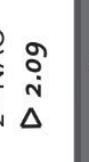 & ن & & & & & & & & & & & & \\
\hline & & & & & & & $\stackrel{1}{0}$ & N & $\stackrel{m}{0}$ & $\stackrel{ \pm}{0}$ & เ & 0 & $\widehat{0}$ & $\infty$ & ด & $\underset{\text { H }}{0}$ & r & $\mathbf{N}$ \\
\hline
\end{tabular}




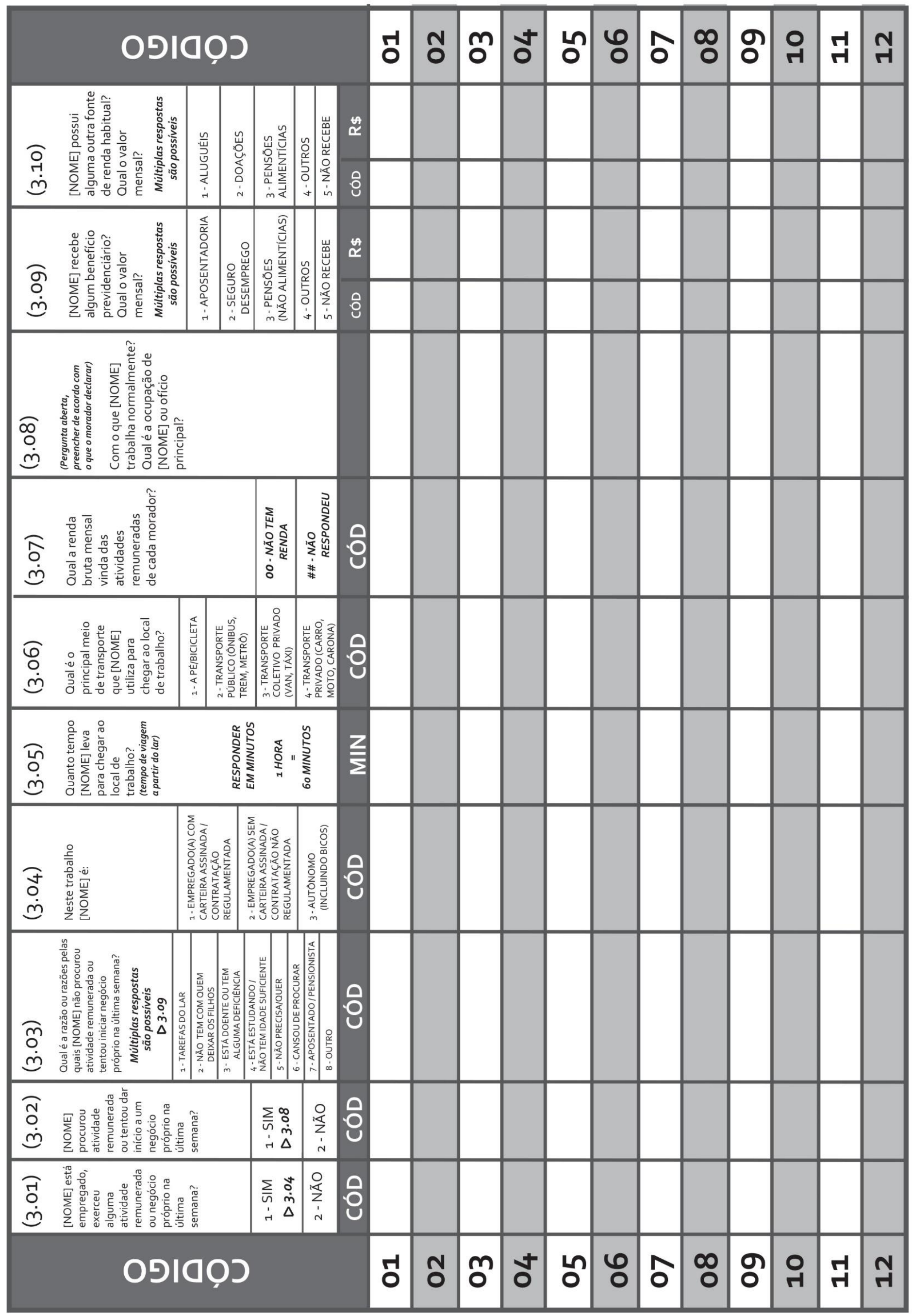



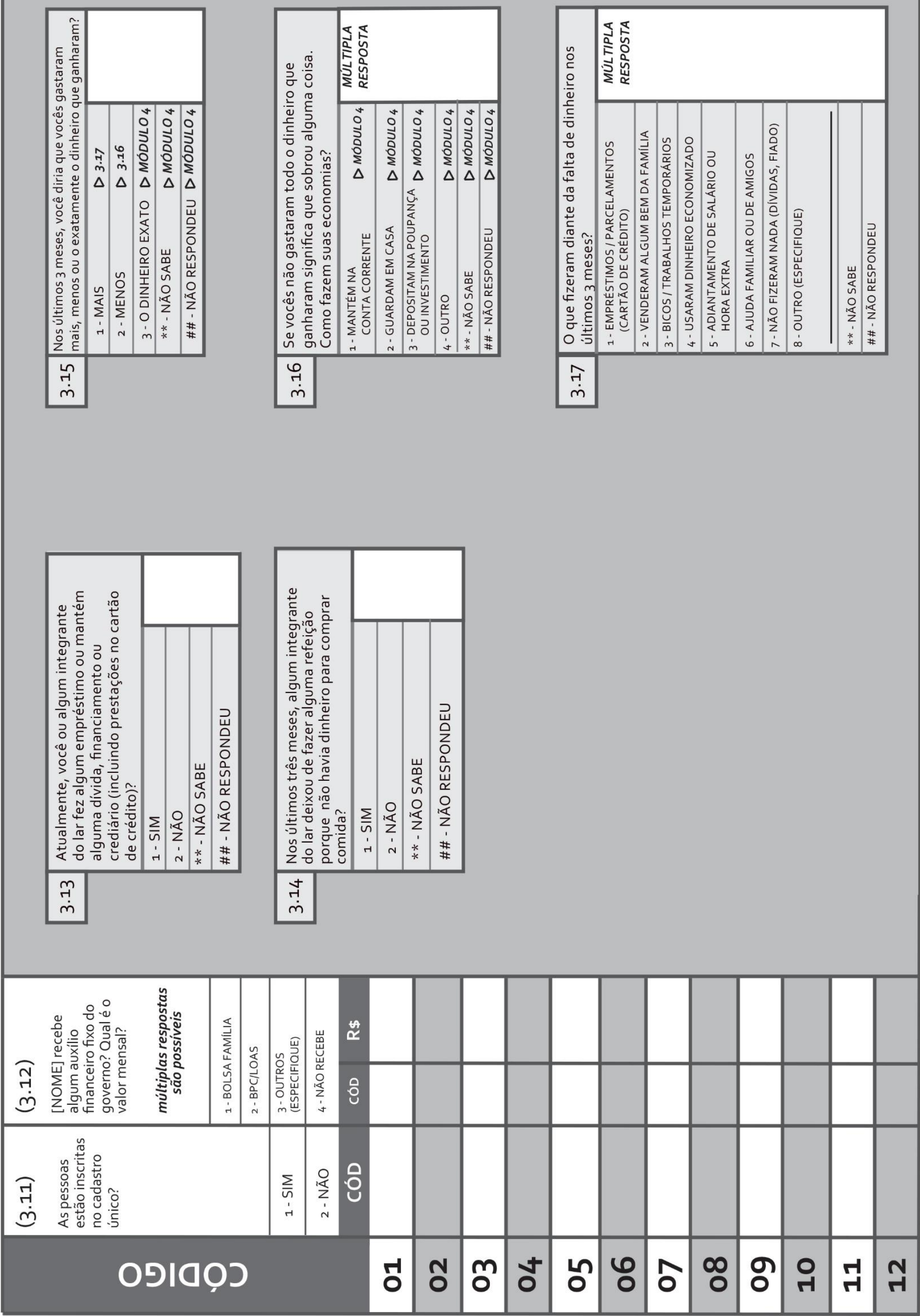


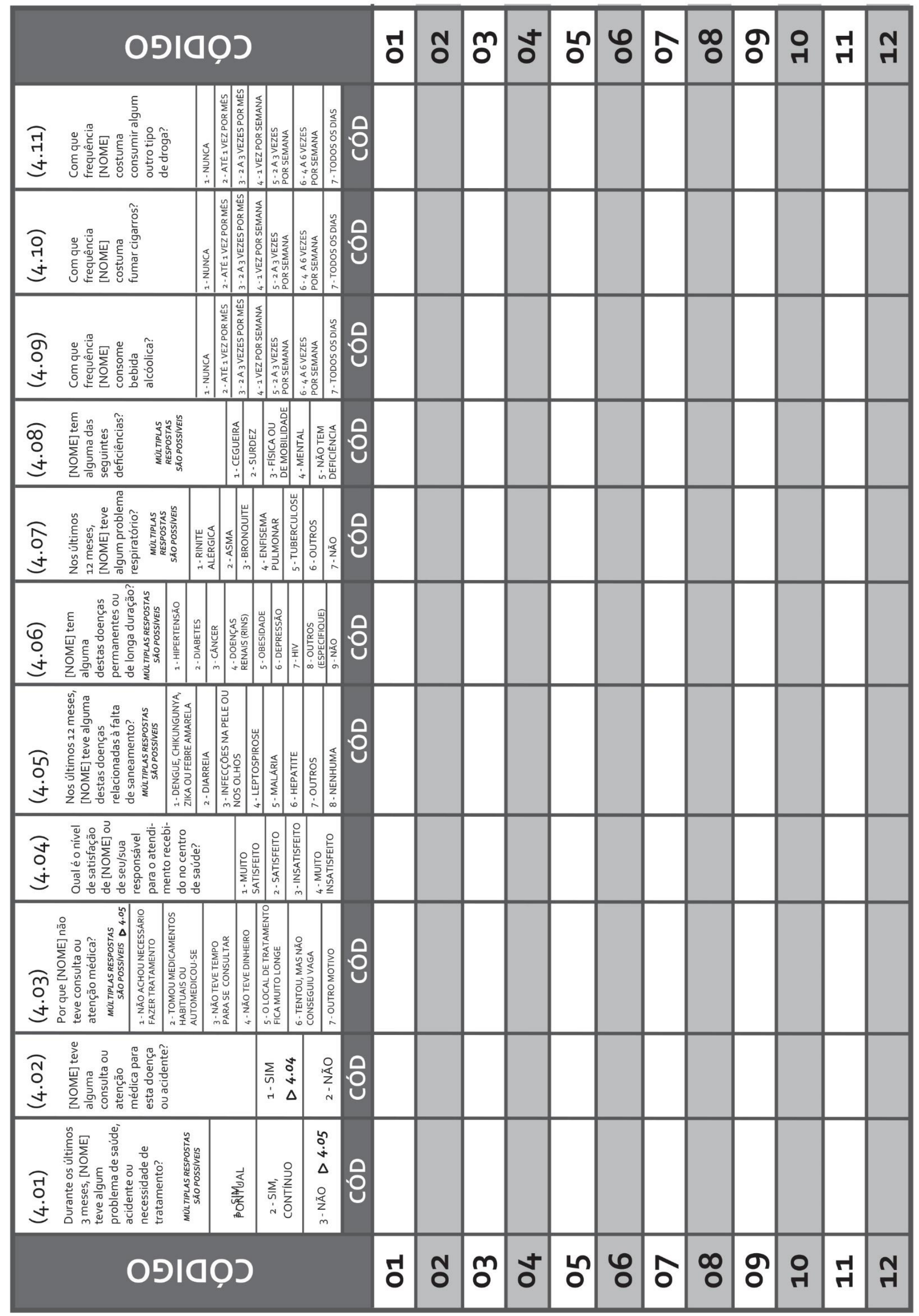




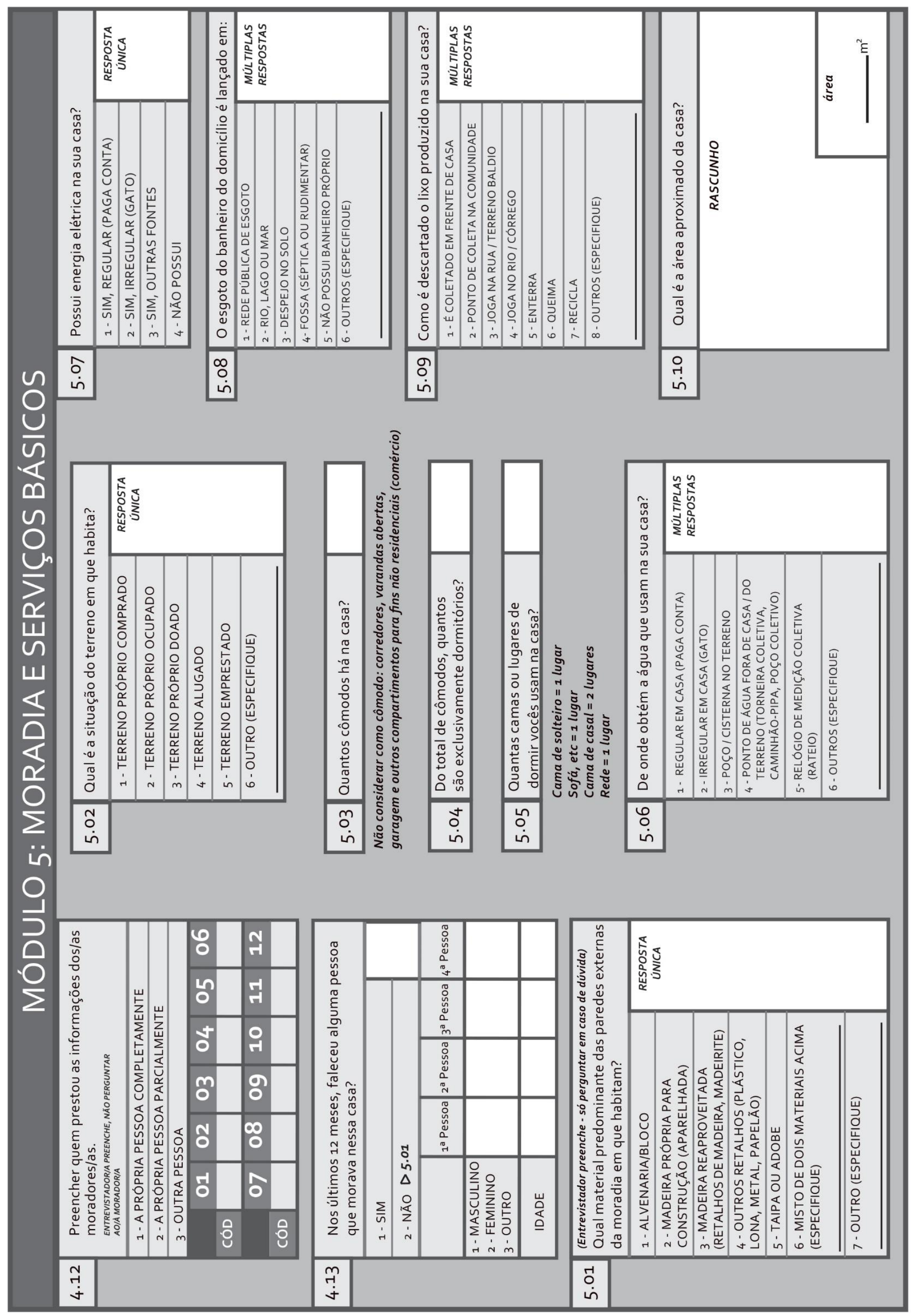




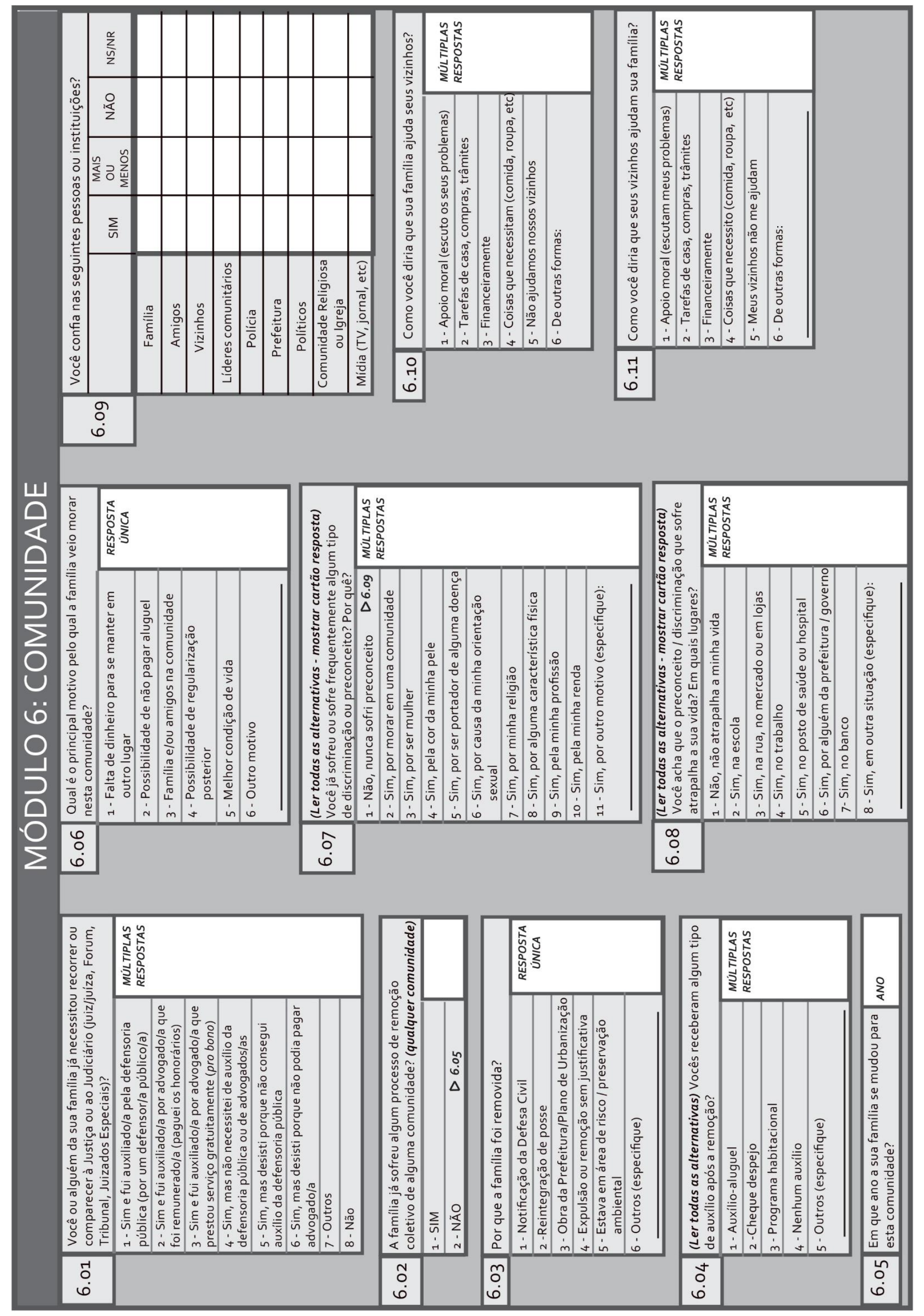




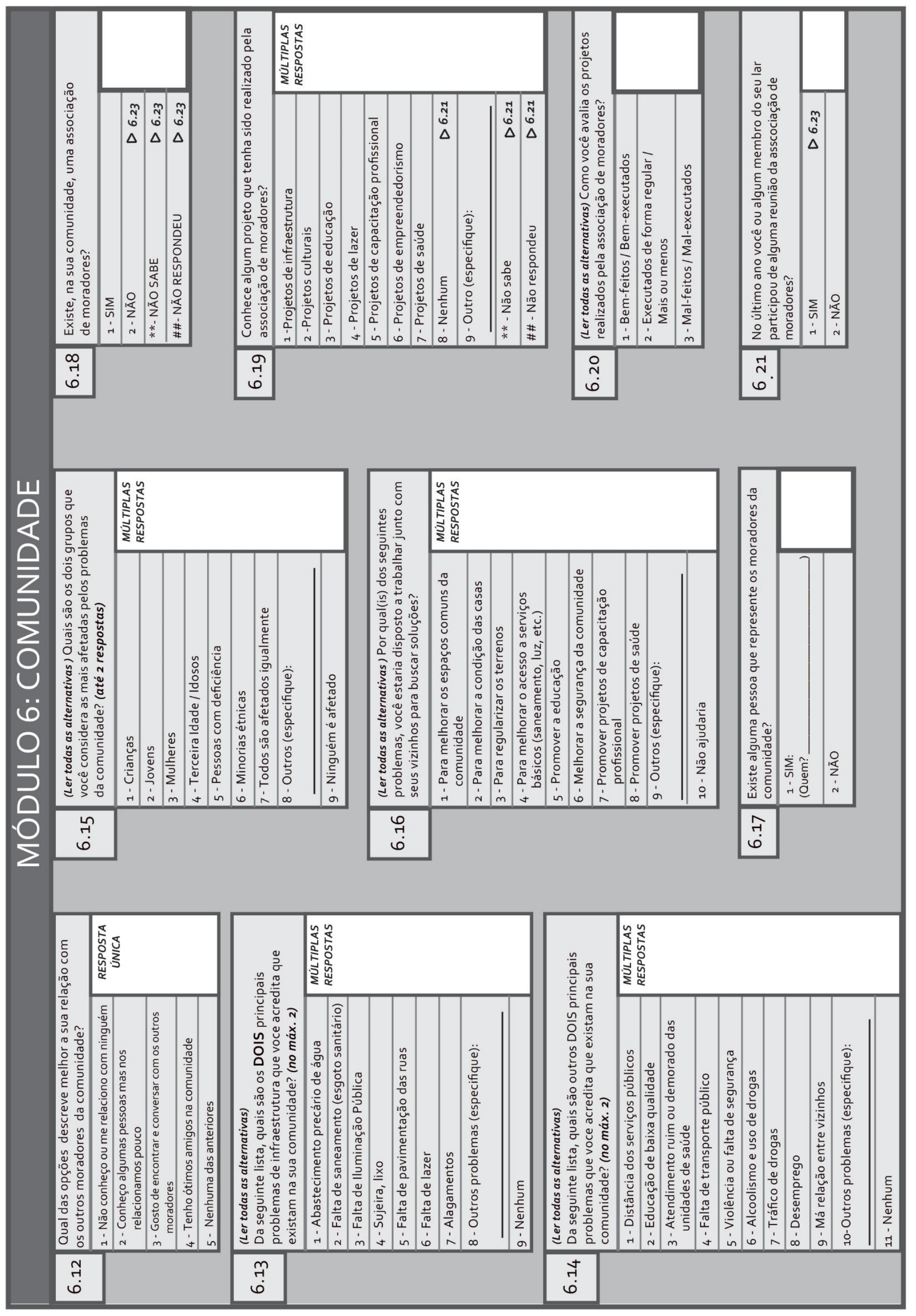




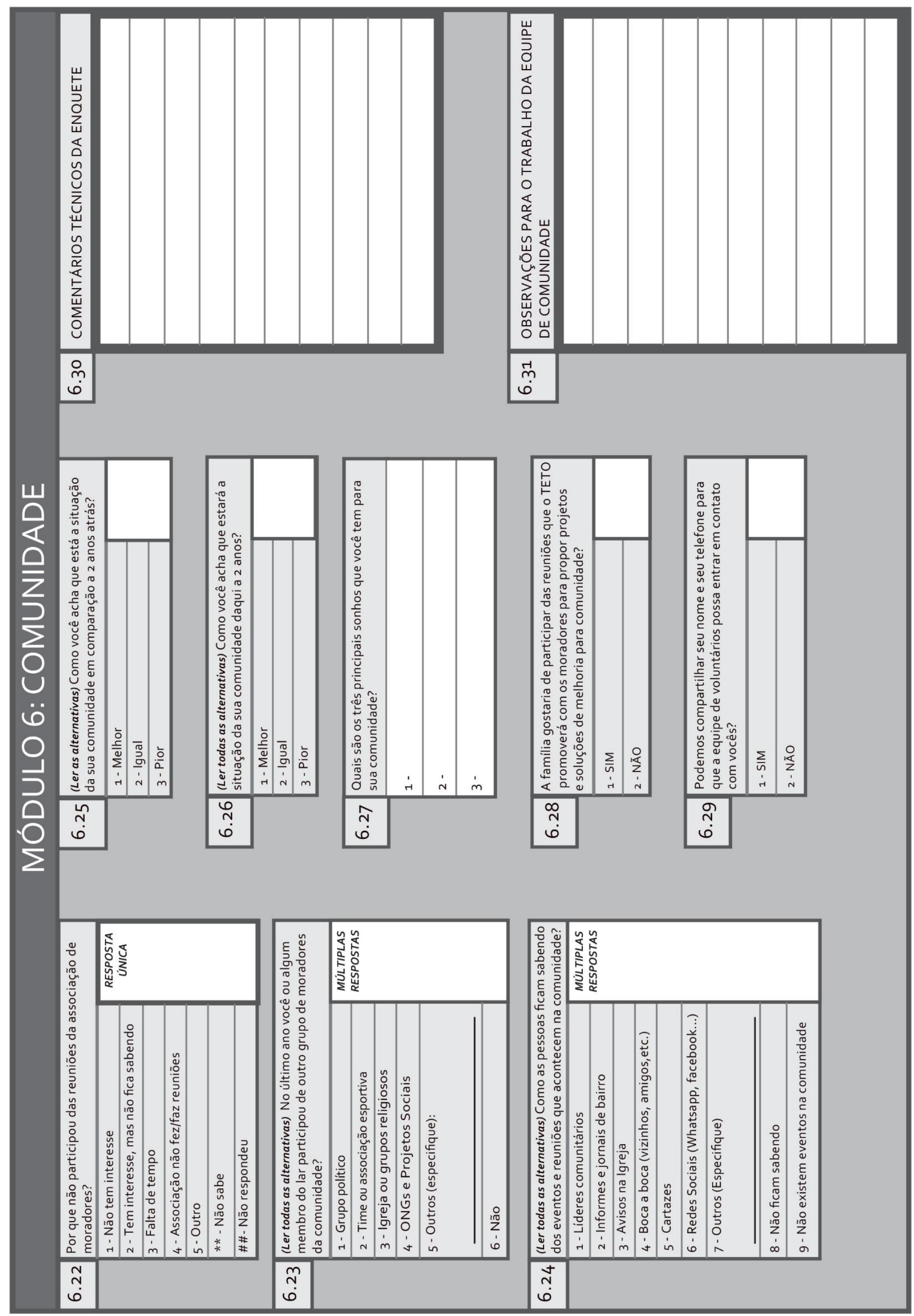

